\title{
ANALYSIS OF GROUND-WATER FLOW IN THE A-SAND AQUIFER AT PARAMARIBO, SURINAME, SOUTH AMERICA
}

By C.B. Hutchinson

U.S. GEOLOGICAL SURVEY

Water-Resources Investigations Report 90-4036

Prepared in cooperation with the

ORGANIZATION OF AMERICAN STATES

Tallahassee, Florida

1990

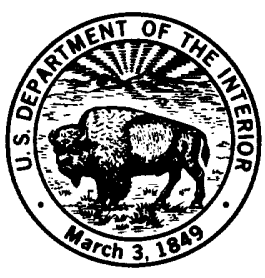


DEPARTMENT OF THE INTERIOR

MANUEL LUJAN, JR., Secretary

U.S. GEOLOGICAL SURVEY

Dallas L. Peck, Director

For additional information write to:

District Chief

U.S. Geological Survey

Suite 3015

227 North Bronough Street

Tallahassee, Florida 32301
Copies of this report may be purchased from:

U.S. Geological Survey

Books and Open-File Reports

Federal Center, Bldg. 810

Box 25425

Denver, Colorado 80225 


\section{CONTENTS}

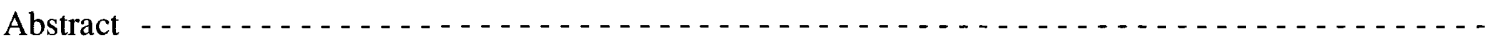

Introduction - . - . - $-1, \ldots$

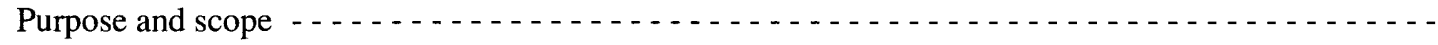

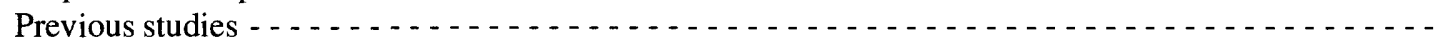

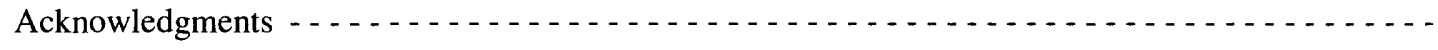

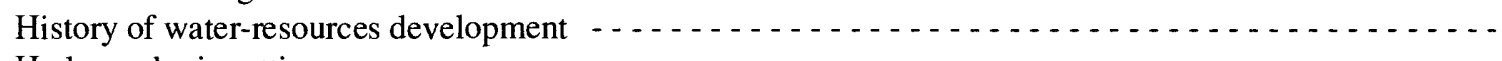

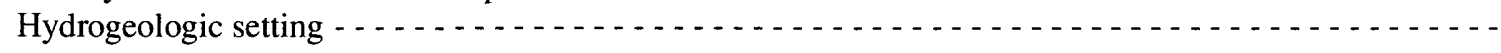

Ground-water levels and movement

Hydraulic properties of the A-Sand aquifer $\ldots \ldots \ldots$

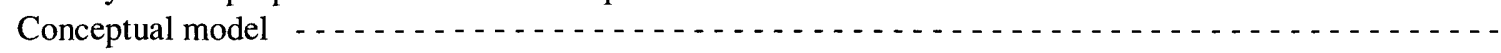

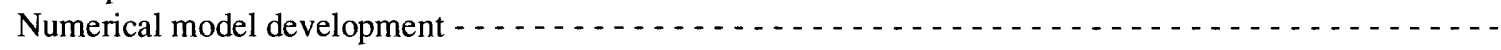

Input parameters

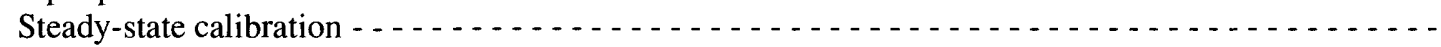

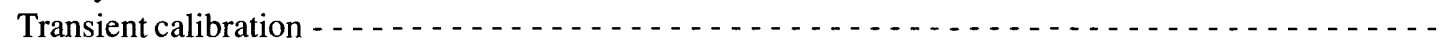

Methodologies for model improvement $\ldots . . \ldots \ldots \ldots$

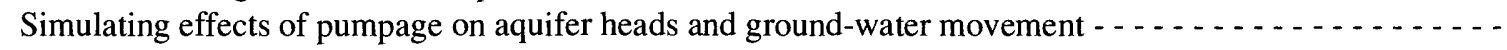

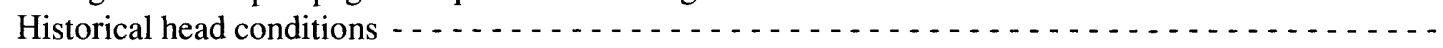

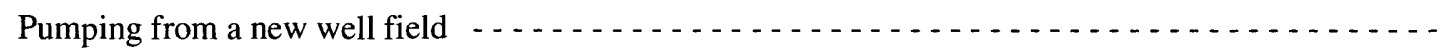

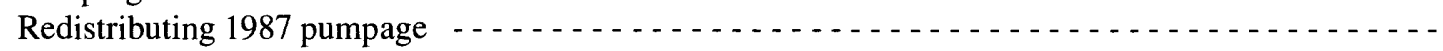

Estimating the rate of saltwater encroachment $\ldots \ldots \ldots$

Assessment of the ground-water flow system using particle-tracking techniques

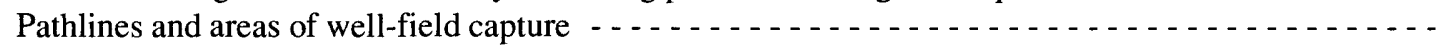

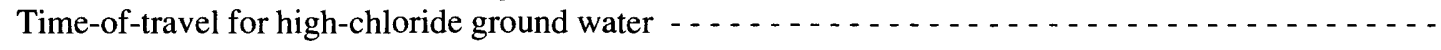

Time-of-travel to well fields _...

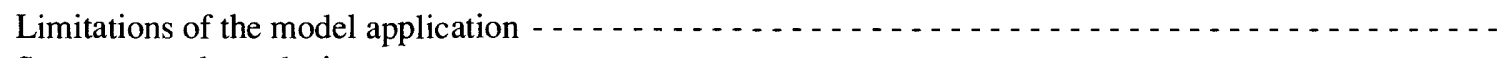

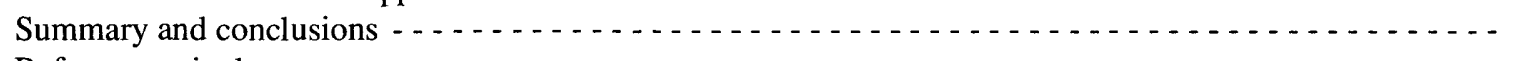

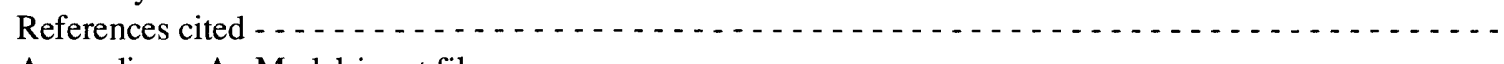

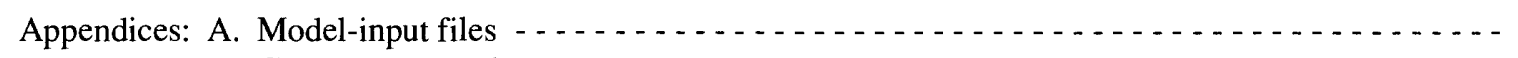

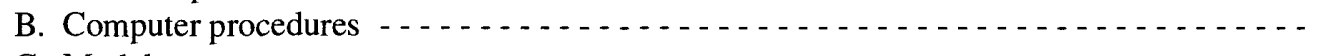

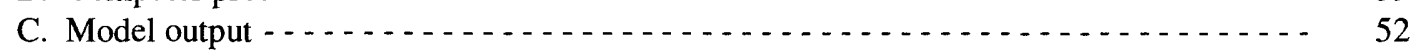

\section{ILLUSTRATIONS}

Figure 1. Map showing location of the model area with well fields and average daily pumping

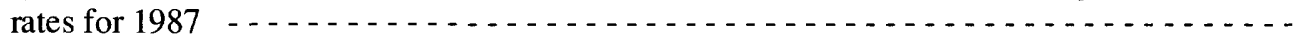

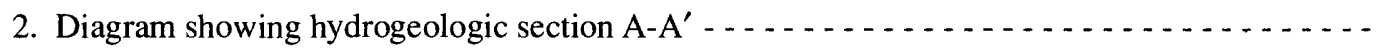

3. Map showing thickness and estimated hydraulic conductivity of the A-Sand aquifer

4. Graphs showing water levels in selected wells and total pumpage from the A-Sand aquifer, 1958-87 $\ldots \ldots \ldots$

5-6. Maps showing:

5. Observation-well network and potentiometric surface of the A-Sand aquifer,

August 1987 - . . . . . . . . . . . . . . . . . . . . . . . . .

6. Inland movement of chloride toward well fields that tap the A-Sand aquifer $\ldots$

7-9. Diagrams showing:

7. Schematic layout of model grid, lateral boundaries, and flow paths $\ldots \ldots \ldots$

8. Schematic north-south cross section with conceptualized flow - . . $\ldots \ldots$

9. Modeling procedures and their relation to the A-Sand aquifer model $\ldots \ldots \ldots \ldots$ 


\section{ILLUSTRATIONS-Continued}

Figure 10. Map showing observed and simulated potentiometric surfaces of the A-Sand aquifer,

1987, for the steady-state calibration - . . . . . . . . . . . . . . . . . . .

11. Graphs showing observed and simulated water levels in the A-Sand aquifer, 1958-87, for the transient calibration - . . . . . . . . . . . . . . . . . . . . 16

12. Maps showing simulated potentiometric surface of the A-Sand aquifer for 1960,1965 , 1970, 1975, 1980, 1985, and $1987 \ldots \ldots$

13-20. Maps showing:

13. Simulated steady-state potentiometric surface of the A-Sand aquifer when a hypothetical new 6,000-cubic-meters-per-day well field is added to existing

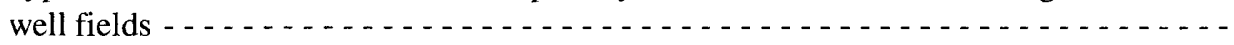

14. Simulated head change with respect to the 1987 potentiometric surface when a hypothetical new 6,000-cubic-meters-per-day well field is added to existing

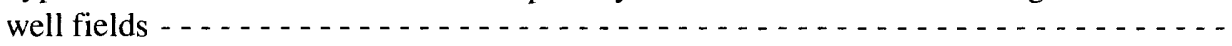

15. Simulated steady-state potentiometric surface of the A-Sand aquifer when a hypothetical new 6,000-cubic-meters-per-day well field is added and pumpage from Zorg en Hoop and Livorno well fields is reduced 20 percent . . . . . . . . . . . . . .

16. Simulated head change with respect to the 1987 potentiometric surface when a hypothetical new 6,000-cubic-meters-per-day well field is added and pumpage from Zorg en Hoop and Livorno well fields is reduced 20 percent . . . . . . . . . . . . . .

17. Pathlines of ground-water flow under 1987 pumping rates and when a hypothetical new 6,000-cubic-meters-per-day well field is added to existing

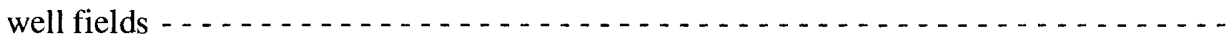

18. Time-of-travel along selected pathlines from the 1958 historical position of the 300 -milligrams-per-liter line of equal chloride concentration for 30 years under 1958-86 average pumping rates - . . . . . . . . . . . . . . . . . . .

19. Time-of-travel along selected pathlines from the 1986 simulated position of the 300-milligrams-per-liter line of equal chloride concentration under 1987 pumping rates - . . . . . . . . . . . . . . . . . . . . . . .

20. Time-of-travel along selected ground-water pathlines to each well field for 30 years under 1987 pumping rates . . . . . . . . . . . . . . . . . . . . .

\section{TABLES}

Table 1. Average daily withdrawals from the A-Sand aquifer well fields, 1958-87

2. Model-input parameters - - - - - - - -

3. Disk-file hierarchy for the A-Sand aquifer ground-water flow model 


\title{
ANALYSIS OF GROUND-WATER FLOW IN THE A-SAND AQUIFER AT PARAMARIBO, SURINAME, SOUTH AMERICA
}

\author{
By C.B. Hutchinson
}

\begin{abstract}
A numerical aquifer-simulation model was developed for a 619-square-kilometer area to help understand the ground-water flow system and to aid in the management of pumpage from the A-Sand aquifer in Paramaribo, Suriname, South America. Thirty years of continuous increases in pumpage from the A-Sand aquifer have created broad cones of depression in the aquifer's potentiometric surface that extend over hundreds of square kilometers. As a result of these water-level declines, the aquifer is experiencing problems of well-field interference and saltwater encroachment.
\end{abstract}

The understanding of the hydrogeology of the A-Sand aquifer was improved during calibration of the model. Aquifer tests had indicated a large variability in hydraulic conductivity; however, an acceptable calibration was achieved by using a uniform hydraulic conductivity of 90 meters per day. Simulated transmissivity of the 2-to 50-meter thick aquifer wedge varies from 180 to 4,500 square meters per day between the southern and northern model boundaries, respectively. The aquifer previously had been conceptualized as being bounded above and below by impermeable beds with the only source of inflow being from the north. However, the model simulation used a leakage coefficient representative of marine clay, and model results indicated that approximately one-third of the pumpage may be derived from vertical leakage. This leakage is divided approximately evenly between aquifer systems above and below the A-Sand aquifer. Contribution to pumpage from storage is insignificant in this thin, confined aquifer.

Three simulations were made to demonstrate how the model can be used as a tool for water management. A transient simulation was made to assess potentiometric-surface changes resulting from pumpage during the period 1958 to 1987. Potentiometric-surface maps for selected years show expanding and coalescing cones of depression as the number of well fields increased from one to six and pumping rates increased from 1,643 to 40,230 cubic meters per day. A hypothetical new well field, with a 6,000 cubic-meter-per-day pumping rate, was simulated to demonstrate how additional pumping can lower the potentiometric surface at existing well fields. Another simulation redistributed pumpage by adding the above hypothetical new well field, but with an equivalent reduction in pumpage at the two most heavily pumped well fields, Zorg en Hoop and Livorno. Head gradients between Zorg en Hoop and the area where chloride concentrations in ground water exceeded 300 milligrams per liter were compared with 1987 gradients to show that redistributing pumpage might slow saltwater encroachment and extend the useful life of the well field by 5 years.

A particle-tracking program was used to assess results of the flow simulations. It was used to delineate pathlines and approximate zones of well-field capture under 1987 pumping conditions and when a hypothetical new 6,000-cubic-meter-per-day well field is added. Four of the six active well fields in 1987 drew' water directly along pathlines from the model boundary, indicating a potential to draw in water with high chloride concentrations. The particle-tracking program also was used to estimate time-of-travel along selected pathlines from the area of high (300 milligrams per liter) chloride concentrations to individual well fields. The simulated velocity averages about 133 meters per year within 4 kilometers of the Livorno well field. Simulated velocities from the area of high chloride concentrations are highest toward the Leysweg and Zorg en Hoop well fields, indicating a high potential for increasing chloride concentrations in water from these well fields.

\section{INTRODUCTION}

In 1987, Paramaribo, Suriname, and nearby areas (fig. 1) on the tropical north coast of South America, withdrew about $40,000 \mathrm{~m}^{3} / \mathrm{d}$ of water from wells 130 to 190 meters deep that tap the A-Sand aquifer. The A-Sand aquifer is bounded above and below by confining units and has no surface outcrop or direct recharge area, except possibly offshore in the Atlantic Ocean. The consequences of 30 years of continually increasing pumpage include: (1) broad cones of depression in the potentiometric surface that extend over hundreds of square kilometers; (2) interference among closely spaced wells and among well fields; and (3) saltwater encroachment, as indicated by increasing chloride concentration. These problems were recognized in the early 1980 's, but until recently, no plan or technique for aquifer management had been developed. 

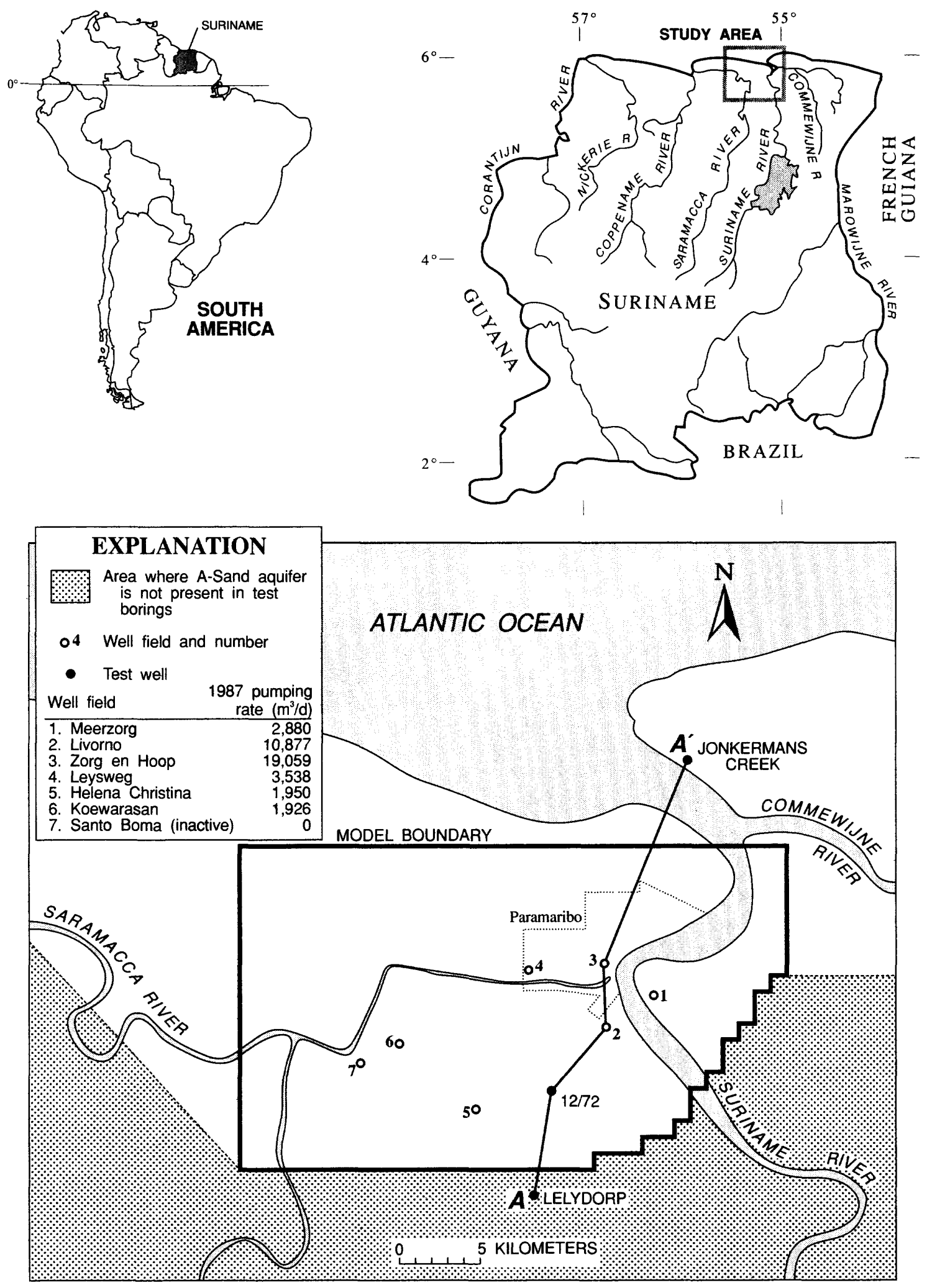

Figure 1.-Location of the model area with well fields and average daily pumping rates for 1987. 
A study, which would provide a technique to aid in the management of the ground-water resource, was conceived in 1985 and sponsored by the Organization of American States (OAS) in conjunction with the Suriname Water Company (SWM) and an equivalent governmental organization, the Water Supply Service Ministry of Natural Resources and Energy (DWV). The U.S. Geological Survey, which was approached in 1985 to conduct the study, completed the compilation of data necessary to construct a digital model of the aquifer system in October and November 1988 at the headquarters of SWM in Paramaribo.

\section{Purpose and Scope}

The purpose of this report is to describe the development of a numerical model of the aquifer system and to illustrate how the model can be used to simulate the response of the A-Sand aquifer to various management alternatives. The area of study occupies $619 \mathrm{~km}^{2}$ and encompasses six active well fields. Conceptualization of the hydrologic system and data input to the numerical model were based on existing engineering reports and historical records. No new data were collected.

A conceptual model of the hydrologic system was developed based on existing literature. Then, based on the conceptualization, a numerical model was designed to simulate the hydrologic system under steady-state and transient conditions. The model's sensitivity to changes in input parameters was tested to determine which hydrologic properties critically affect simulation accuracy and, therefore, should be further defined through field studies. Next, hypothetical simulations were run to show how the model can be used to evaluate various management alternatives by providing information on well-field interference and potential for saltwater encroachment. Output from the numerical model was then used with a particle-tracking program to generate pathlines and time-of-travel information used to estimate the rate of movement of saline water toward public-supply wells.

\section{Previous Studies}

Results of several studies were used to delineate the hydrogeologic framework of the A-Sand aquifer and provide insight into aquifer hydraulic characteristics. A report published through the United Nations Development Programme (1972) describes a 4-year study that established the hydrogeologic framework in coastal Suriname. Major aquifers were defined and tested, and a generalized water-supply plan for Paramaribo and its metropolitan area was provided. A follow-up report by International Water Supply
Consultants (1981, in Dutch) from the Netherlands focused on expansion of the water supply by testing other aquifer systems south of Paramaribo. That report also presented a transmissivity map, model grid, and transient simulation results of six pumping plans for the A-Sand aquifer. Little other information concerning the model was described. The model program and data files were not provided to the Suriname Government because there were insufficient computer facilities in the country in 1983. A third report, prepared by Organization of American States' (OAS) consulting hydrologist Albert Mente (1984), described a ground-water monitoring plan with wells that corresponded to those initially monitored in the United Nations Development Programme (UNDP) study. This report provided the impetus for generating the modeling investigation described herein. A fourth report, by Planning Research Corporation Engineering, Inc. (1988), provides maps of three well fields, graphs of water-quality data, and up-to-date well-field production figures.

Two reports that document computer programs were utilized in the A-Sand aquifer study. A report by McDonald and Harbaugh (1988) documents the U.S. Geological Survey's modular ground-water flow model and describes how to create the data files called for by the program. A subsequent report by Pollock (1989) documents a particle-tracking postprocessing program called "Modpath," which computes pathlines based on output from the modular model.

\section{Acknowledgments}

The author wishes to express his appreciation for the considerable cooperation received from governmental agencies and especially from personnel whose interest in the project contributed substantially to the successful completion of this study.

They are:

\section{Suriname Water Company-}

Ir. Th.L.O. Goedhart, Managing Director, R. Pawirodihardjo, S. Simbhoedathpanday, Tjon A Fat, S. Ramjiawan, V. Martodikromo, D. Thakoerdajal, R. Wongso, H. Etnel, and G. Aliredjo.

Water Supply Service, Ministry of Natural Resources-

E.T. Tsai Meu Chong, Under-Director of Mining, J.P. Telgt, and E. Ng. Asmoredjo.

The author is particularly indebted to Tjon A Fat for responding to requests for computer equipment, to V. Martodikromo for typing the original manuscript, to R. Wongso for drafting the illustrations, and to "Panday" who was a guide and companion. The author also 
recognizes the assistance and guidance provided by A. Mente, OAS, consulting hydrologist from Brazil, who recommended that the U.S. Geological Survey be involved in the project and by other personnel of the Organization of American States, Department of Regional Development, including Neville Gunther, Paramaribo, Suriname, and Jorge Blanco, Washington, D.C.

\section{HISTORY OF WATER-RESOURCES DEVELOPMENT}

Exploitation of water resources within the A-Sand aquifer began in mid-1958 with the establishment of the Zorg en Hoop well field (fig. 1). Since then, the SWM established well fields and treatment facilities at
Leysweg (1973) and Livorno (1980). The DWV established small rural supply well fields at Santo Boma (1960-73), Meerzorg (1963), Koewarasan (1969), and Helena Christina (1981). The Zorg en Hoop, Leysweg, Koewarasan, and Helena Christina well fields also have production wells that tap the overlying aquifer. The average annual pumping rates from the A-Sand aquifer are listed in table 1. As indicated in this table, the average pumping rate increased from $1,643 \mathrm{~m}^{3} / \mathrm{d}$ in 1958 to $40,230 \mathrm{~m}^{3} / \mathrm{d}$ in 1987 . Between 1983 and 1987 , pumpage was fairly stable, which has been reflected in a stabilization of the potentiometric surface of the A-Sand aquifer. Approximately 227 million cubic meters were withdrawn from 1958 to 1987 . The water was used for municipal supply. Pumpage for irrigation and industry in the study area is negligible.

Table 1.-Average daily withdrawals from the A-Sand aquifer well fields, 1958-87

(Values are in cubic meters per day)

\begin{tabular}{|c|c|c|c|c|c|c|c|c|}
\hline Year & $\begin{array}{c}\text { Zorg en } \\
\text { Hoop }\end{array}$ & Livorno & Leysweg & Meerzorg & $\begin{array}{c}\text { Helena } \\
\text { Christina }\end{array}$ & $\begin{array}{l}\text { Koewar- } \\
\text { assan }\end{array}$ & $\begin{array}{l}\text { Santo } \\
\text { Boma }\end{array}$ & Total \\
\hline 1958 & 1,643 & & & & & & & 1,643 \\
\hline 1959 & 2,740 & & & & & & & 2,740 \\
\hline 1960 & 2,740 & & & & & & 548 & 3,288 \\
\hline 1961 & 2,740 & & & & & & 548 & 3,288 \\
\hline 1962 & 2,740 & & & & & & 548 & 3,288 \\
\hline 1963 & 2,740 & & & 547 & & & 548 & 3,835 \\
\hline 1964 & 8,219 & & & 547 & & & 548 & 9,314 \\
\hline 1965 & 8,767 & & & 547 & & & 548 & 9,862 \\
\hline 1966 & 10,958 & & & 547 & & & 548 & 12,053 \\
\hline 1967 & 10,958 & & & 547 & & & 548 & 12,053 \\
\hline 1968 & 10,958 & & & 547 & & & 548 & 12,053 \\
\hline 1969 & 16,438 & & & 548 & & 548 & 548 & 18,082 \\
\hline 1970 & 16,438 & & & 548 & & 548 & 548 & 18,082 \\
\hline 1971 & 16,986 & & & 548 & & 548 & 548 & 18,630 \\
\hline 1972 & 16,986 & & 4,931 & 548 & & 548 & 548 & 23,561 \\
\hline 1973 & 15,068 & & 4,931 & 1,370 & & 548 & & 21,917 \\
\hline 1974 & 15,342 & & 5,205 & 1,370 & & 548 & & 22,465 \\
\hline 1975 & 15,342 & & 7,671 & 1,370 & & 548 & & 24,931 \\
\hline 1976 & 15,342 & & 6,027 & 2,192 & & 548 & & 24,109 \\
\hline 1977 & 17,260 & & 8,013 & 2,192 & & 548 & & 28,013 \\
\hline 1978 & 17,260 & & 8,013 & 2,192 & & 548 & & 28,013 \\
\hline 1979 & 17,260 & & 8,013 & 2,192 & & 548 & & 28,013 \\
\hline 1980 & 17,260 & & 8,013 & 2,192 & & 548 & & 28,013 \\
\hline 1981 & 18,630 & 7,671 & 7,397 & 2,465 & & 548 & & 36,711 \\
\hline 1982 & 16,438 & 9,589 & 6,849 & 2,465 & 1,917 & 548 & & 37,806 \\
\hline 1983 & 16,164 & 8,219 & 8,219 & 2,400 & 1,950 & 2,400 & & 39,352 \\
\hline 1984 & 15,081 & 10,360 & 2,131 & 2,400 & 1,950 & 2,400 & & 34,322 \\
\hline 1985 & 14,789 & 10,353 & 3,645 & 2,400 & 1,950 & 2,400 & & 35,537 \\
\hline 1986 & 16,238 & 10,976 & 3,708 & 2,400 & 1,950 & 2,400 & & 37,672 \\
\hline 1987 & 19,059 & 10,877 & 3,538 & 2,880 & 1,950 & 1,926 & & 40,230 \\
\hline $\begin{array}{l}1958-86 \\
\text { average }\end{array}$ & 12,398 & 1,971 & 3,199 & 1,209 & 335 & 596 & 245 & 19,953 \\
\hline
\end{tabular}




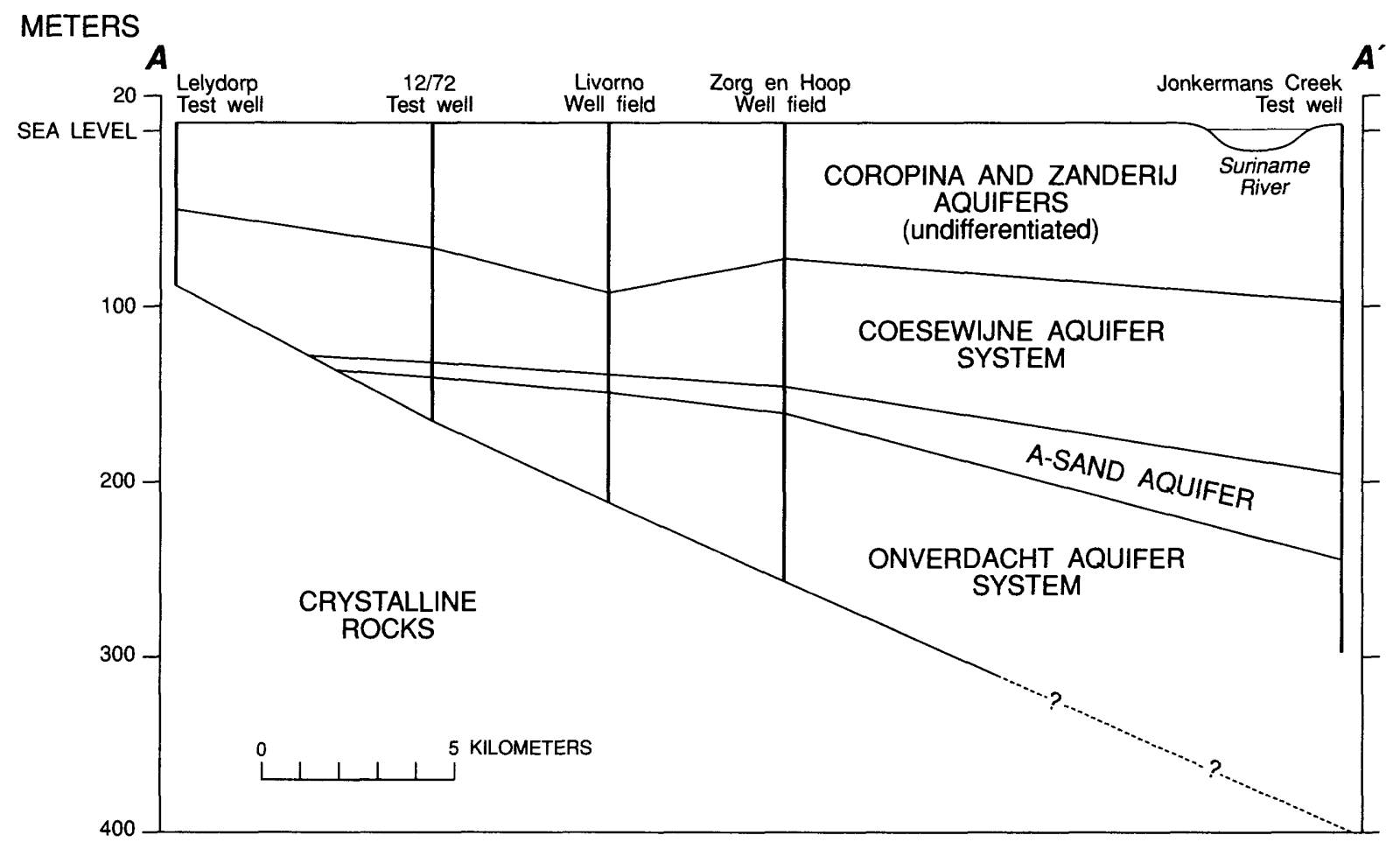

Figure 2.-Hydrogeologic section A-A'.

\section{HYDROGEOLOGIC SETTING}

Suriname may be divided into two hydrogeologically distinct provinces (fig. 1). About 80 percent of the country (the southern part) is underlain by Precambrian crystalline rocks, and the remaining part, a northern coastal basin, is underlain by unconsolidated sediments. In the southern province, surface water is the major source of supply, whereas in the northern province, which encompasses Paramaribo, ground water is the major source.

The coastal basin consists of sequential sands and clays that thicken northward from the pinchout at the crystalline rocks (fig. 2). The wedge is approximately $40-\mathrm{km}$ wide and is about 300 -meters thick at the northern boundary of the modeled area near the Atlantic Coast. Abundant ground water occurs in the coastal basin under confined conditions with artesian heads near land surface. Water quality is variable. The aquifers consist mainly of coarse-grained, angular quartz sand that is somewhat kaolinitic. Hydrogeologic units of interest in this study are:

1. The Onverdacht aquifer system consists of multiple sand lenses within the Onverdacht Formation of Paleocene to middle Eocene age. The top of the formation is generally between 120 and 250 meters below land surface and slopes from south to north. This wedge-shaped system has a maximum thickness of about 125 meters within the modeled study area. Permeable zones contain saline water and, therefore, are not a source of potable supply. The Onverdacht is hydrologically important as a potential source of upward leakage to the overlying A-Sand aquifer.

2. The A-Sand aquifer consists of a coarse-grained sand of middle Eocene to Oligocene age and overlies the Onverdacht Formation. Wells completed in this aquifer typically yield about $1,000 \mathrm{~m}^{3} / \mathrm{d}$. The aquifer thickens from about 2 meters in the south, where beds are truncated by crystalline rocks, to about 40 meters at the north coast (fig. 3). The aquifer also thickens toward the southeast Bakhuis fault, which was mapped in the United Nations Development Programme (1972, Enclosure III-3) study. Lateral aquifer boundaries are the crystalline rocks in the south and pinchouts just east of the Suriname River and westward in the vicinity of the Saramacca River. There is no known physical boundary or seafloor outcrop in the north.

3. The Coesewijne aquifer system consists of multiple sand lenses within the Coesewijne Formation of Miocene age. The principal permeable zone lies at depths of 110 to 130 meters beneath Paramaribo. 
The system has a maximum thickness of about 100 meters within the modeled study area. It contains freshwater in the northwest part of the city, whereas in other areas, the chloride concentration of the water exceeds $250 \mathrm{mg} / \mathrm{L}$. The Coesewijne aquifer system is less permeable than the underlying A-Sand aquifer, but it may be an important source of downward leakage to the heavily pumped A-Sand aquifer. Pumpage from Coesewijne is less than 10 percent of the total pumpage from the A-Sand aquifer.

4. The Coropina and Zanderij aquifers consist of undifferentiated sands and clays of Pliocene to Pleistocene age. Their maximum thickness is about 100 meters, however, they are not an important source of ground water within the study area. Near the coast, the chloride concentration is greater than $250 \mathrm{mg} / \mathrm{L}$ and well yields are low compared to the A-Sand aquifer. Approximately $50 \mathrm{~km}$ south of Paramaribo, a large well field is being developed in this system to augment pumpage from the A-Sand aquifer.

\section{Ground-Water Levels and Movement}

Ground-water levels in the A-Sand aquifer have been measured intermittently since 1958 . Hydrographs for three wells that have the most measurements are shown in figure 4. The hydrographs show a prepumping level in the late 1950's of about 3 meters above sea level. Measurements during the late 1960's were reported in the United Nations Development Programme (1972, fig. III-43) study, and measurements during the mid-1980's were taken from a long-term monitoring program instituted by Mente (1984). The hydrographs show gradual declines in water levels until about 1985 when a leveling off occurred. Between 1985 and 1987, pumping from all well fields, except Zorg en Hoop, was constant, and when water levels stabilized in 1985 , it is probable that a quasi-steady-state flow condition existed. Under this dynamic equilibrium condition, aquifer storage was not changing, and water that was being pumped from the A-Sand aquifer was being replenished by leakage and inland movement of saltwater.
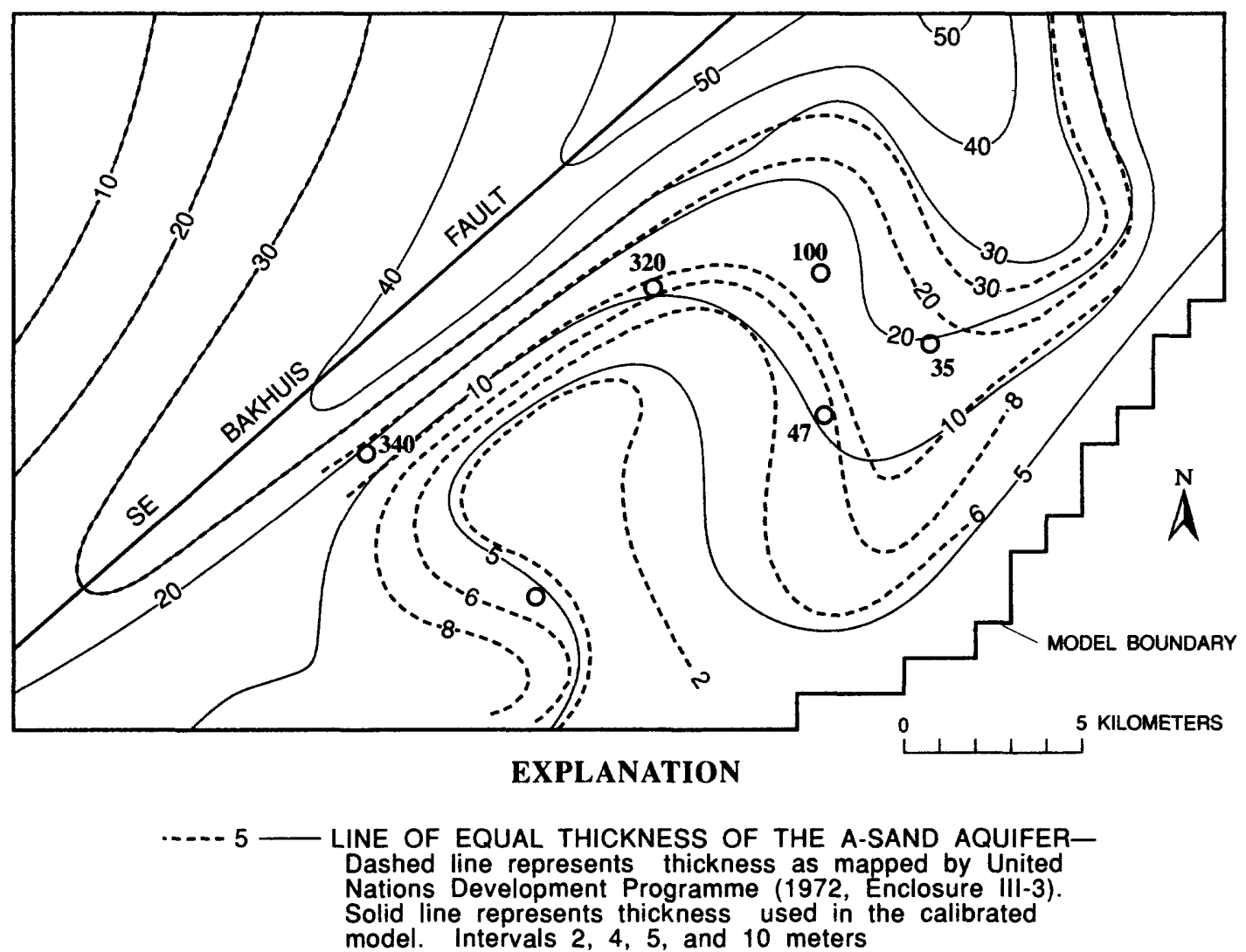

O 340 WELL-FIELD-Open circle is at approximate center of well field. Number is estimated hydraulic conductivity, in meters per day (Mente, 1984, p. 56)

Figure 3.-Thickness and estimated hydraulic conductivity of the A-Sand aquifer within the modeled area. 

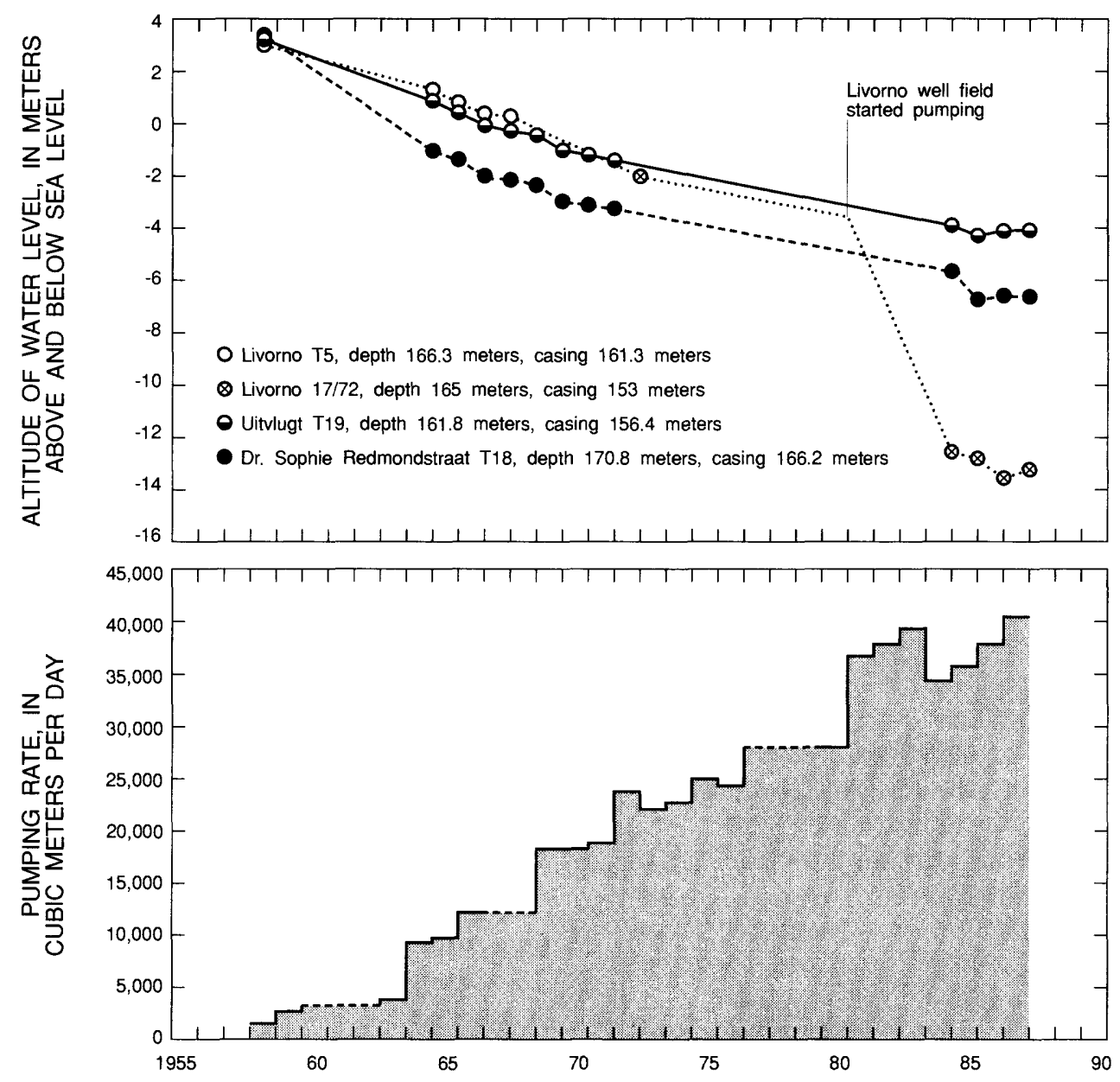

Figure 4.-Water levels in selected wells and total pumpage from the A-Sand aquifer, 1958-87.

The potentiometric surface of the A-Sand aquifer for August 1987 is shown in figure 5. The heavily pumped Livorno and Zorg en Hoop well fields are encompassed by deep, broad cones of depression that coalesce with smaller cones at nearby well fields. The 1987 map represents an average pumping condition of 40,230 $\mathrm{m}^{3} / \mathrm{d}$, as indicated in table 1 . Water-level declines of more than 5 meters have occurred since predevelopment time throughout the $619-\mathrm{km}^{2}$ mapped area. The greatest declines, between 15 and 20 meters, have occurred at the Livorno and Zorg en Hoop well fields. A steep gradient north of Zorg en Hoop is a probable indicator of a source of inflow. Spacing of contours to the south and east indicates that relatively little flow is being derived from those areas. Thickness and transmissivity of the A-Sand aquifer decrease to the south; thus, less flow from that region would be expected.

Further evidence of inflow from the north is the dramatic southward shift between 1958 and 1972 in lines of equal chloride concentration, which represents movement in the brackish transition zone between saltwater in the Atlantic Ocean and freshwater inland in the A-Sand aquifer (Mente, 1984, fig. 16). Figure 6 shows the estimated positions of the $250-\mathrm{mg} / \mathrm{L}$ chloride lines for 1958, 1972, and 1986. Between 1958 and 1972 , the $250-\mathrm{mg} / \mathrm{L}$ line was estimated to have moved 2,400 meters in the vicinity of Zorg en Hoop. By 1986, wells in the northern half of the well field produced water with more than $300 \mathrm{mg} / \mathrm{L}$ of dissolved chloride, as did wells in the eastern half of the Leysweg well field (Planning Research Corporation Engineering, Inc., 1988, figs. 2.1.9 and 2.1.14).

\section{Hydraulic Properties of the A-Sand Aquifer}

Little data have been reported on hydraulic conductivity, transmissivity, leakance, storage coefficient, and porosity of the A-Sand aquifer. The United Nations Development Programme (1972, p. 52) study reported hydraulic conductivity values at 12 sites, based on "old incomplete data." The values are variable, but generally range from 20 to $100 \mathrm{~m} / \mathrm{d}$, although some values were as high as about $300 \mathrm{~m} / \mathrm{d}$. 
The variability may be related to well construction and development, testing procedures, or aquifer heterogeneity. Because of the variability and the unknown method by which the values were calculated, a constant hydraulic conductivity value of $90 \mathrm{~m} / \mathrm{d}$ was estimated. Transmissivity, based on this estimate of hydraulic conductivity, ranges from $180 \mathrm{~m}^{2} / \mathrm{d}$ at the southern aquifer boundary, where the aquifer is 2-meters thick, to $4,500 \mathrm{~m}^{2} / \mathrm{d}$ along the southeast Bakhuis fault and north coastal area, where the thickness is 50 meters (fig. 3). Transmissivity calculated using aquifer thickness and estimated hydraulic conductivity does not compare well with point transmissivities calculated by multiplying reported values of hydraulic conductivity by thickness, or with the range of transmissivity reported for the A-Sand aquifer, between 2,000 and $4,000 \mathrm{~m}^{2} / \mathrm{d}$ for a test at Leysweg (United Nations Development Programme, 1972 , p. 52). However, the calculated transmissivity of $900 \mathrm{~m}^{2} / \mathrm{d}$ compares closely with the $950 \mathrm{~m}^{2} / \mathrm{d}$ derived from a test at Livorno (United Nations Development Programme, 1972, fig. III-45). That a model calibration was achievable using a constant value for hydraulic conductivity suggests that the porous medium may have a more uniform nature than indicated by the single-well tests.

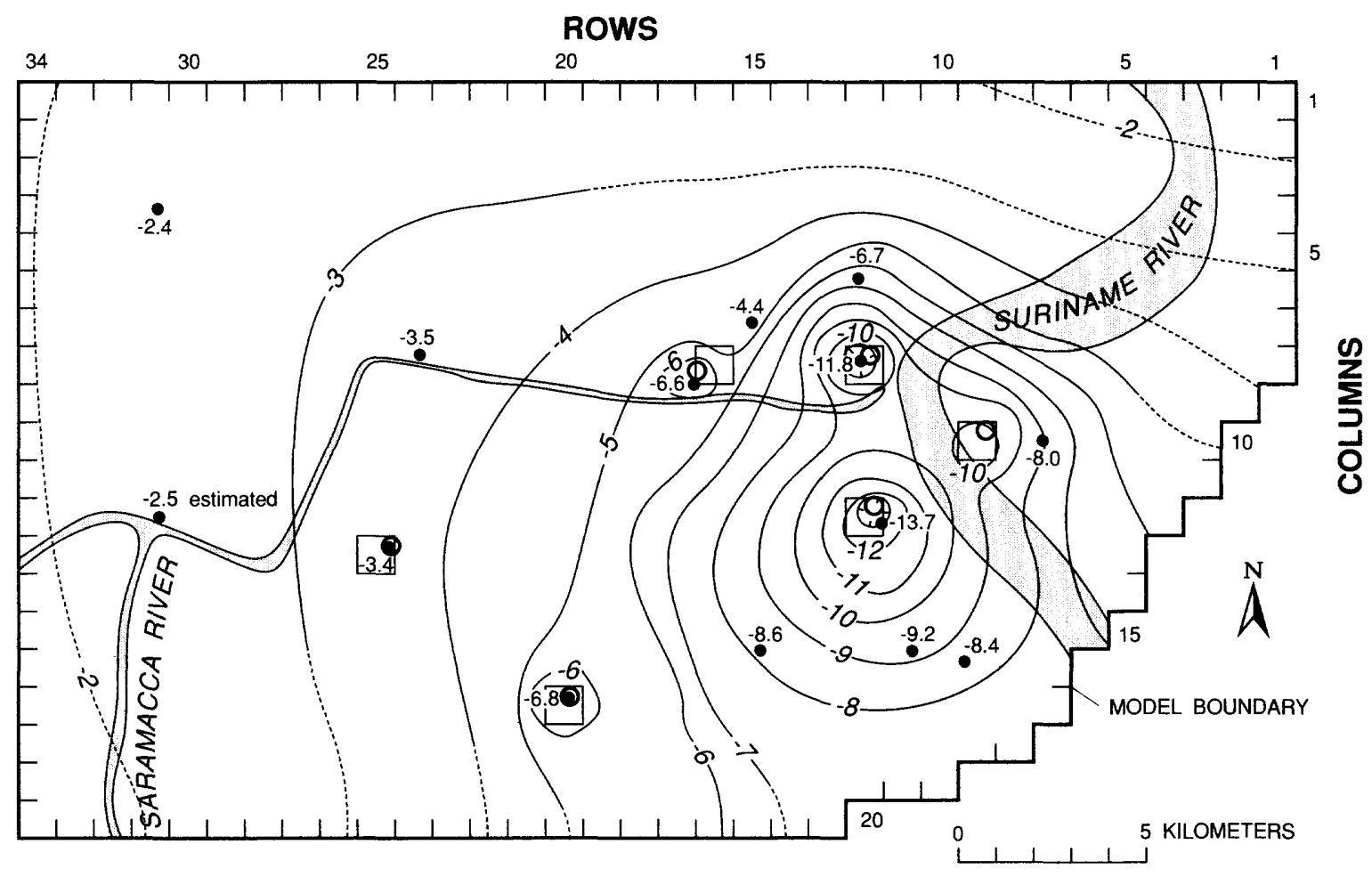

EXPLANATION

- -2.... POTENTIOMETRIC CONTOUR-Shows altitude of potentiometric surface in August 1987. Contour interval 1 meter. Dashed where inferred. Datum is Normal Suriname Level

9 WELL-FIELD GRID BLOCK-Shows model grid block and open circle at approximate center of well field

-6.8 OBSERVATION WELL AND NUMBER-Number is altitude of potentiometric surface, in meters. Datum is Normal Suriname Level. Altitude of water level and well name and number are:

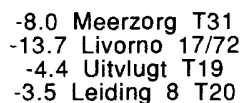

-3.5 Leiding 8 T20

-2.5 Uitkijk T21

$$
\begin{gathered}
-9.2 \text { Taut Lui Faut } 1 / 70 \\
-6.7 \text { Dr. S. Redmondstraat T18 } \\
-6.8 \text { H. Christina } 31 / 71
\end{gathered}
$$$$
-2.4 \text { Garnizoenspad } 25 / 72
$$

Figure 5.-Observation-well network and potentiometric surface of the A-Sand aquifer, August 1987. 
Storage coefficients of $3.0 \times 10^{-4}$ and $2.0 \times 10^{-5}$ have been determined from aquifer tests at Livorno and Leysweg, respectively (United Nations Development Programme, 1972, figs. III-44 and III-45). Because the aquifer is about 10 -meters thick at these sites, specific storage is probably in the range of $3.0 \times 10^{-5} \mathrm{~m}^{-1}$ to $2.0 \times 10^{-6} \mathrm{~m}^{-1}$. Effective porosity of the A-Sand aquifer was estimated to be in the range of 0.07 to 0.15 (United Nations Development Programme, 1972, p. 52). This estimate seems low in light of the typical values of 0.1 to 0.3 that have been reported for specific yield of sand (Driscoll, 1986, p. 67). International Water Supply
Consultants (1981, p. 18) used an effective porosity of 0.25 in calculations of ground-water traveltime in the A-Sand aquifer.

A calculation was made to check estimated effective porosity values independently. From figure 6 , the $250 \mathrm{-mg} / \mathrm{L}$ line of equal chloride concentration moved 2,400 meters toward Zorg en Hoop in 14 years, or $0.47 \mathrm{~m} / \mathrm{d}$. The estimated hydraulic conductivity of the aquifer is $90 \mathrm{~m} / \mathrm{d}$. From the simulation of historical water levels, the average head difference between the $250-\mathrm{mg} / \mathrm{L}$ line of equal chloride concentration and Zorg en Hoop from 1958-72 was 2.6 meters. Effective porosity can be calculated from the equation:

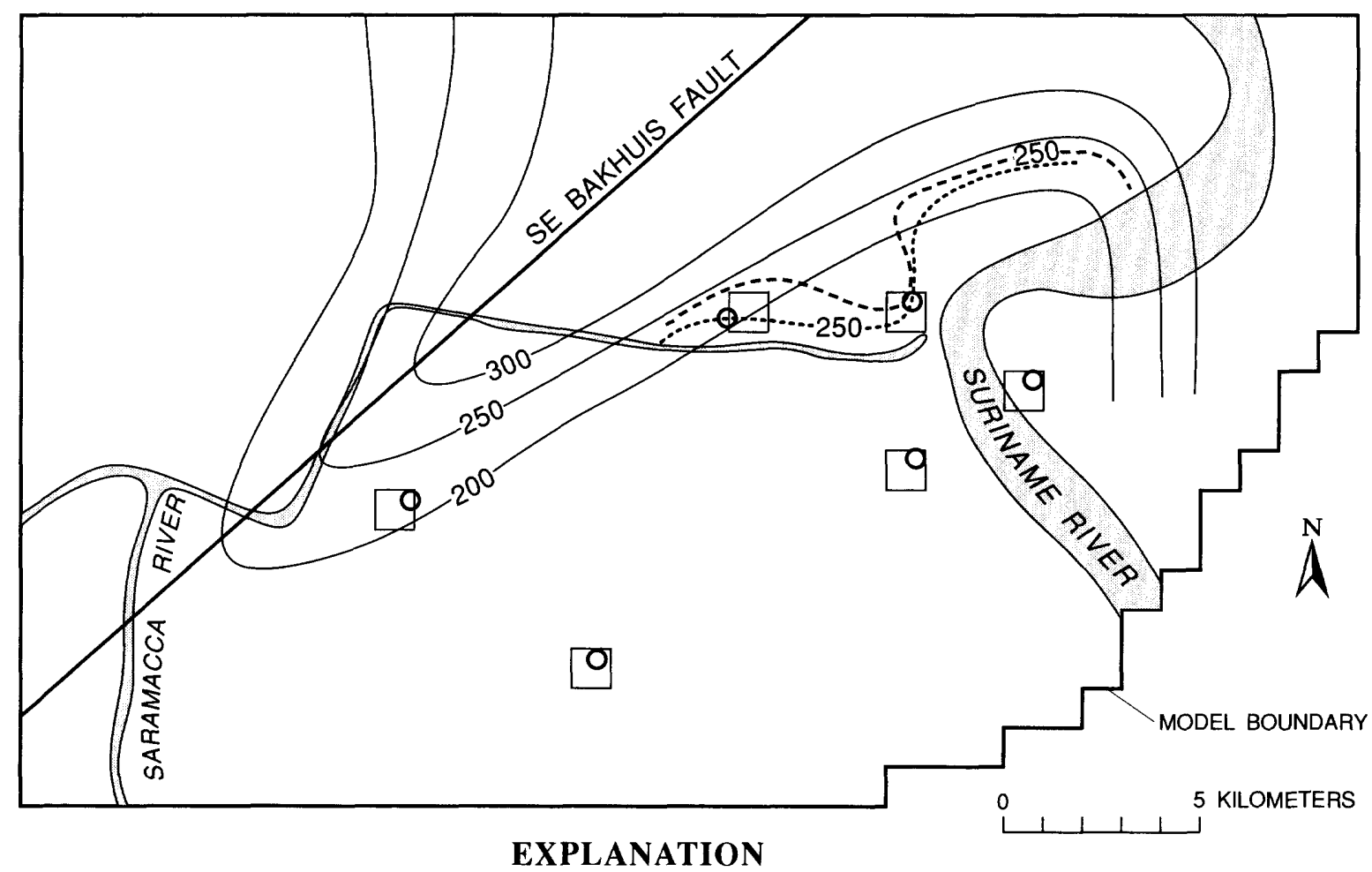

9 WELL-FIELD GRID BLOCK-Shows model grid block and open circle at approximate center of well field

LINES OF EQUAL CHLORIDE CONCENTRATION-Show chloride concentrations for indicated years.

-200- LINES FOR 1958- Have an interval of 50 milligrams per liter (United Nations Development Programme, 1972, fig. III-3).

---250--- LINE FOR 1972-Shows position of the 250-milligrams-per-liter concentration mapped by Mente (1984, figs. 8 and 16).

...-.250..... LINE FOR 1986-Shows position of the 250-milligrams-perliter concentration based on data by Planning Research Corporation Engineering, Inc. (1988, figs. 2.1.9 and 2.1.14)

Figure 6.-Inland movement of chloride toward well fields that tap the A-Sand aquifer. 


$$
\mathrm{n}=\frac{\mathrm{K}}{\overline{\mathrm{v}}} \cdot \frac{\Delta \mathrm{h}}{1}
$$

where

$\mathrm{n}=$ effective porosity;

$\mathrm{K}=$ hydraulic conductivity, $90 \mathrm{~m} / \mathrm{d}$;

$\Delta \mathrm{h}=$ head difference, $2.6 \mathrm{~m}$;

1 = length of flow path, $2,400 \mathrm{~m}$;

$\overline{\mathrm{v}}=$ average linear velocity of ground-water flow, $0.47 \mathrm{~m} / \mathrm{d}$.

The calculated effective porosity, based on the above values for equation variables, is 0.21 . The porosity value can be considered as a maximum because of vertical leakage along the flow path. Leakage would tend to dilute the chloride concentration, thereby moderating the velocity used in equation 1 . The calculated porosity falls within the range of estimated values.

\section{CONCEPTUAL MODEL}

The preceding analysis of the hydrogeologic framework forms the basis for developing a conceptual model of ground-water flow, which is transformed into mathematical terms in the numerical model. Procedures in the conceptualization include the development of an understanding of the flow system's boundary conditions and the mechanics of ground-water movement.

Figure 7 is a schematic diagram that shows the lateral hydrogeologic boundaries. The southern boundary of the A-Sand aquifer coincides approximately with the A-Sand aquifer-crystalline rock contact. Part of the eastern boundary also coincides with a pinchout of the A-Sand aquifer. Because the A-Sand aquifer terminates at a featheredge, this is considered a no-flow boundary.
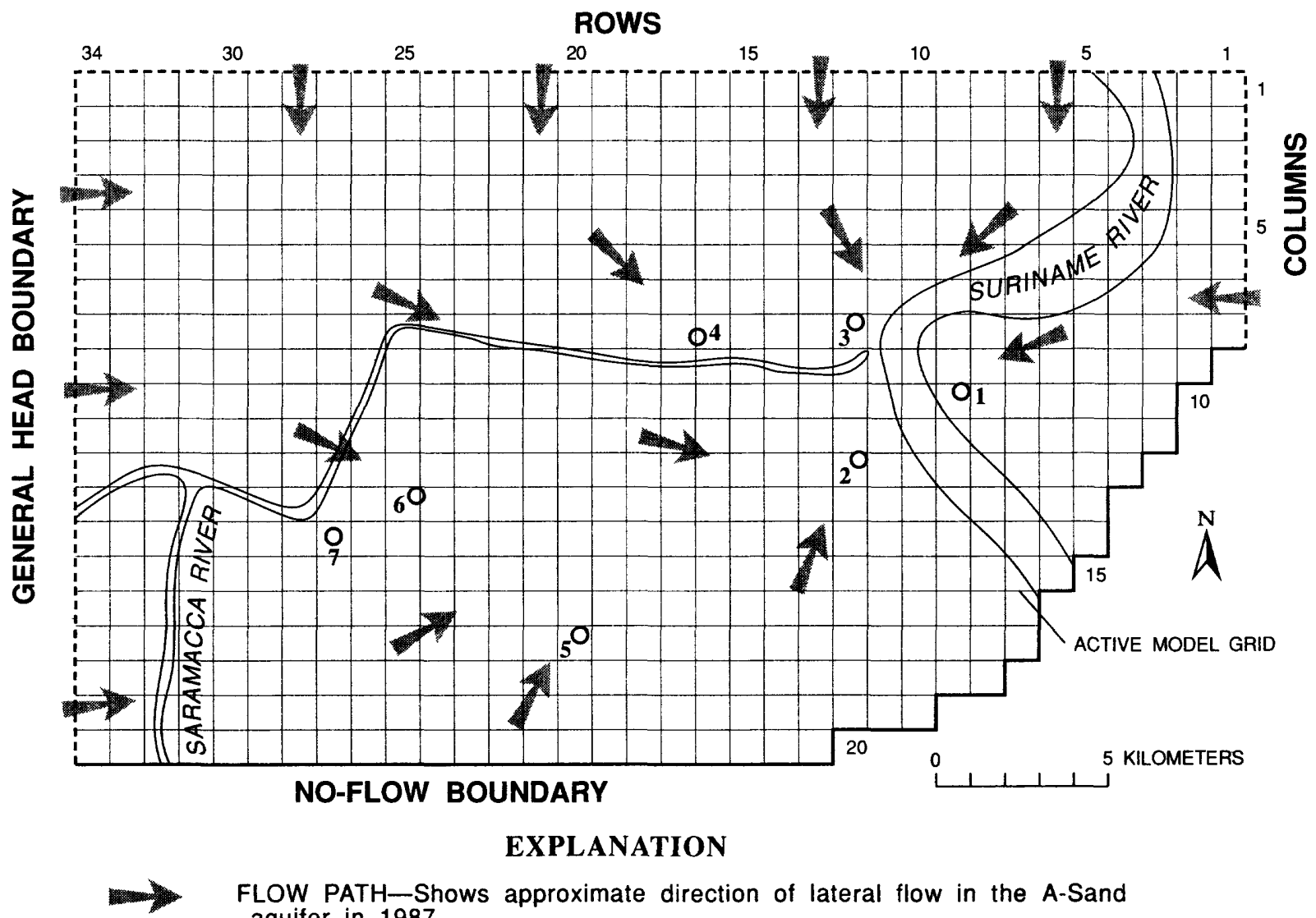

FLOW PATH-Shows approximate direction of lateral flow in the A-Sand aquifer in 1987

59 WELL-FIELD GRID BLOCK-Shows model grid block and open circle at approximate center of well field

WELL FIELDS
1. Meerzorg
5. Helena Christina
2. Livorno
3. Zorg en Hoop
6. Koewarasan
4. Leysweg
7. Santo Boma

Figure 7.-Schematic layout of model grid, lateral boundaries, and flow paths. 
The A-Sand aquifer is known to occur beyond the model area to the west, north, and northeast. The model boundary is considered to be a "general head boundary" through which water is allowed to enter or leave the system at rates that are dependent upon the aquifer properties and hydraulic gradients near the boundary.

The A-Sand aquifer had previously been conceptualized as nonleaky, being bounded above and below by impermeable beds, with the only source of replenishment of pumped water being lateral flow from the north (United Nations Development Programme, 1972; International Water Supply Consultants, 1981; Mente, 1984). One basis for this concept is that measured drawdowns during aquifer tests of less than 2 days follow the Theis nonleaky type curve, or plots as a perfectly straight line on a semilogarithmic graph. Supporting evidence is given in that, if the system were leaky, saltwater would have been drawn in long ago from overlying or underlying aquifers or both. Another factor is that isotope data indicate that water in the A-Sand aquifer is 13,000 to 20,000 years old; hence, water is not being recharged and is not moving rapidly through the system.

There are several contradictions to the nonleaky aquifer conceptual model. First, low to moderately leaky aquifers may not necessarily show a leaky response during aquifer tests of less than 2 days (such as those conducted at Livorno and Leysweg). Second, there are numerous references in the report by the United Nations Development Programme (1972, p. 104 and Annex 10, p. 7, for example) to suspected hydraulic interconnection between the A-Sand and overlying and underlying aquifers. Also, chloride concentrations inland in some wells at Livorno, where drawdown is severe, have increased markedly between 1976 and 1986, whereas chloride concentration in the coastward Leysweg and Zorg en Hoop well fields have not shown similar increases as would be expected for a nonleaky system (Planning Research Corporation Engineering, Inc., 1988). Perhaps the most convincing argument for support of a leaky system is that marine clays, such as those that compose confining units above and below the A-Sand, typically have a hydraulic conductivity within the range of $10^{-4}$ to $10^{-7} \mathrm{~m} / \mathrm{d}$ (Freeze and Cherry, 1979, p. 29). Depending upon sand content, hydraulic conductivity of a confining unit could be at the high end of this range. Therefore, the leakance coefficient of a 10-meter thick sandy clay confining unit may be on the order of $10^{-5}(\mathrm{~m} / \mathrm{d}) / \mathrm{m}$ or more. Thus, it seems reasonable to assign these confining units values of hydraulic conductivity characteristic of sandy marine clays rather than treating them as impermeable beds.
Figure 8 is a schematic north-south vertical section that shows the conceptual model with three aquifer layers. The top and bottom layers correspond to the Coesewijne and Onverdacht aquifer systems, respectively, and are separated from the A-Sand aquifer by confining units. Under prepumping conditions prior to 1958 , there was upward flow. The head of 4 meters above sea level in the Onverdacht aquifer system caused water to flow upward through the A-Sand aquifer where the head was 3 meters and into the Coesewijne aquifer system where the head was 2 meters above sea level. Under pumping conditions existing in the 1980's, the A-Sand aquifer head has been lowered below heads in the Coesewijne and Onverdacht aquifers systems. The pumped water is replaced by downward leakage from the Coesewijne aquifer system, upward leakage from the Onverdacht aquifer system, and lateral movement across boundaries on the west, north, and northeast. Assumptions are that heads in the Onverdacht and Coesewijne aquifers systems are not affected by pumping from the A-Sand aquifer. These aquifer systems are at least four times as thick as the A-Sand aquifer (fig. 2) and contain large volumes of ground water in storage above and below the pumped aquifer. Drawdown in these aquifer systems probably is negligible on a regional scale; however, at the well fields, it may be important.

\section{NUMERICAL MODEL DEVELOPMENT}

A digital model can be used to simulate a hydrologic system and its response to hydrologic stress, such as pumping. A numerical finite-difference method is applied to solve partial differential equations of groundwater flow. A digital model was selected over analytical techniques because of the complexity of the hydrologic system, especially with respect to well-field interference. For example, complex patterns of pumping can be represented in a digital model, whereas it is cumbersome and difficult to represent more than two pumping centers analytically.

The three-dimensional Modular model (McDonald and Harbaugh, 1988) was selected because of its ability to simulate the conceptualized hydrogeologic system and because it has been adapted to run on personal computers. The model is "quasi-three-dimensional" in that it computes two-dimensional $(x, y)$ flow in a middle layer that is recharged by vertical leakage from inactive layers above and below. Because of the lack of evidence of vertical head differences within the A-Sand aquifer, the aquifer was deemed suitable for simulation as a two-dimensional system. 
Procedures employed in setting up the Modular model for simulating the response of the A-Sand aquifer to hydraulic stresses are diagrammed in figure 9. First, the hydrogeologic system was assigned three layers with vertical leakage to the middle A-Sand aquifer layer from constant-head layers above and below. Lateral boundaries are no-flow boundaries on the south and southeast, which correspond to limits of the aquifer. General-head boundaries on the west, north, and northeast allow the exchange of water between the modeled area and the area beyond the boundary where the aquifer, hypothetically, is a continuous region. Lateral flow rates are based on a head of 3 meters in the outer region, a calculated head in the boundary cell, and a conductance that generally corresponds to aquifer transmissivity. The conceptualized framework in a 34- by $20-\mathrm{km}$ area was discretized in space and time and each $1-\mathrm{km}$-square grid block and year-long time step was assigned hydraulic properties and temporal information.
In the southeast corner, grid blocks are inactive where the A-Sand aquifer pinches out, leaving an active grid of 619 blocks. A steady-state calibration was achieved when the model accurately simulated the 1987 potentiometric surface. Next, aquifer storage coefficient and pumping history were entered and adjusted during the transient calibration in which long-term hydrographs were simulated. With the independent calibrations each simulating observed conditions, the model was considered to be calibrated and ready to simulate hypothetical pumping scenarios.

\section{Input Parameters}

Input parameters for the steady-state calibration, transient calibration, and predictive model are listed in table 2. Parameters were estimated from available reports. Where estimates of certain parameters were not available, representative values were selected from ranges in published reports.

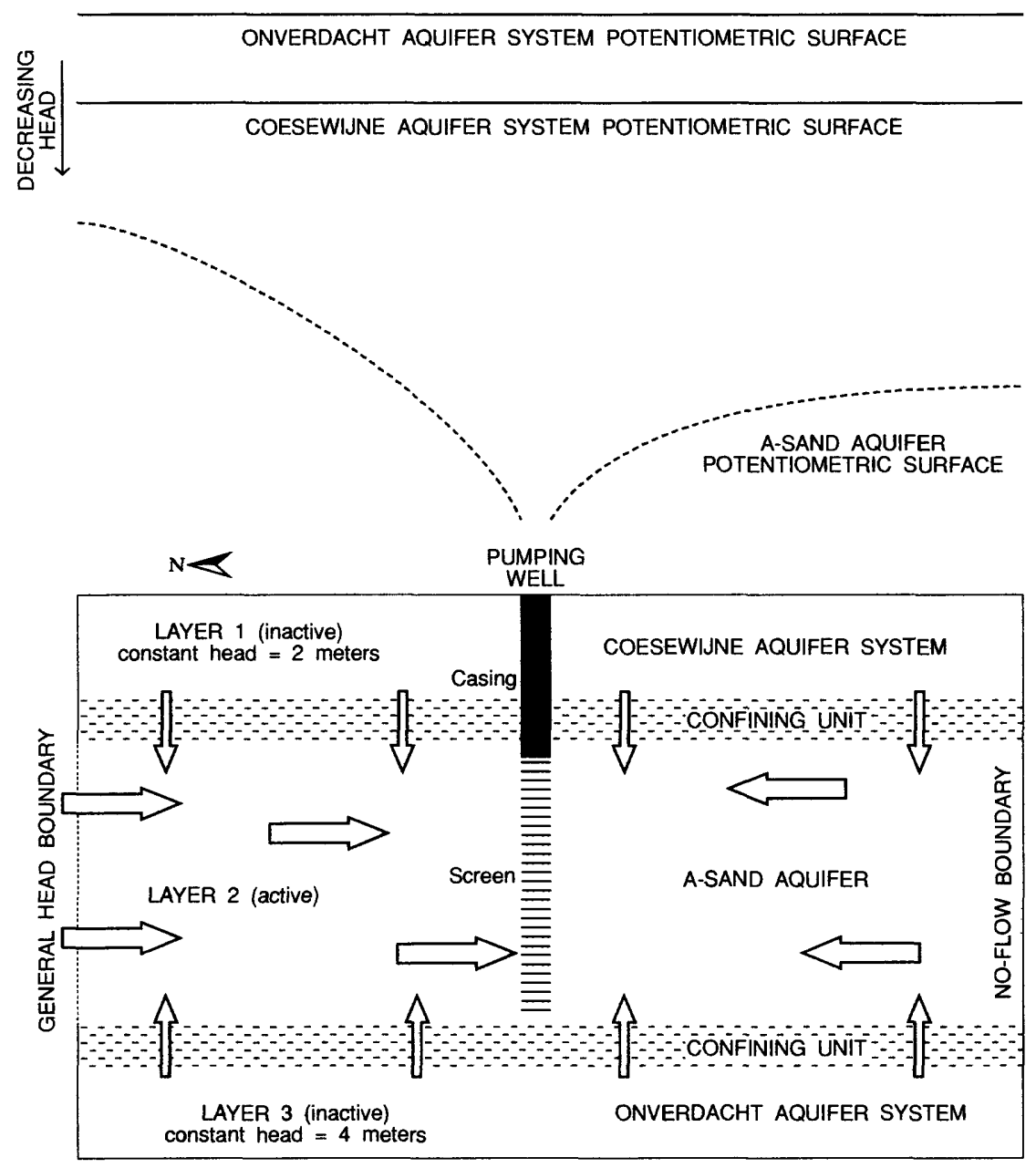

Figure 8.-Schematic north-south cross section with conceptualized flow. 


\section{Steady-State Calibration}

A steady-state calibration was achieved by methodically adjusting model-input parameters until the simulated heads matched the observed 1987 heads shown in figure 5 . Figure 10 shows the comparison between the potentiometric surface contoured from observed heads and the machine-contoured surface simulated by the model. The surfaces are similar, with deep cones of depression centered at Zorg en Hoop and Livorno. Residuals, calculated by subtracting the simulated head from the observed head at the 619 active grid blocks, indicated that simulated heads are within a range of 1.3 meters above and 1.4 meters below observed heads, the mean is 0.15 meter below observed heads, the standard deviation is 0.43 meter, and the mean of the absolute values of the residuals is 0.36 meter. In comparing the 14 water-level control points (fig. 5), the greatest calibration error occurred at the Zorg en Hoop well field where the simulated head was 1.1 meters too low. The water balance indicated that 33 percent of the pumpage is derived from leakage, divided approximately evenly between aquifer systems above and below the A-Sand aquifer, and 67 percent is from boundary flow. Every grid block contributed leakage to the A-Sand aquifer, and the average over 619 active blocks is about $22\left(\mathrm{~m}^{3} / \mathrm{d}\right) / \mathrm{km}^{2}$. Leakage during 1987 would form an equivalent $8-\mathrm{mm}$ deep sheet of water over the modeled area. The calibration was judged to be excellent considering that simulated heads matched the observed heads, as indicated by the close agreement of the simulated potentiometric surface to the actual one. It should be kept in mind, however, that the actual potentiometric surface was constructed from only 14 control points (fig. 5) and there may be substantial error in areas of no data.

A sensitivity test was made to demonstrate the viability of a nonleaky aquifer model, as previously had been considered. As expected, when leakance was set

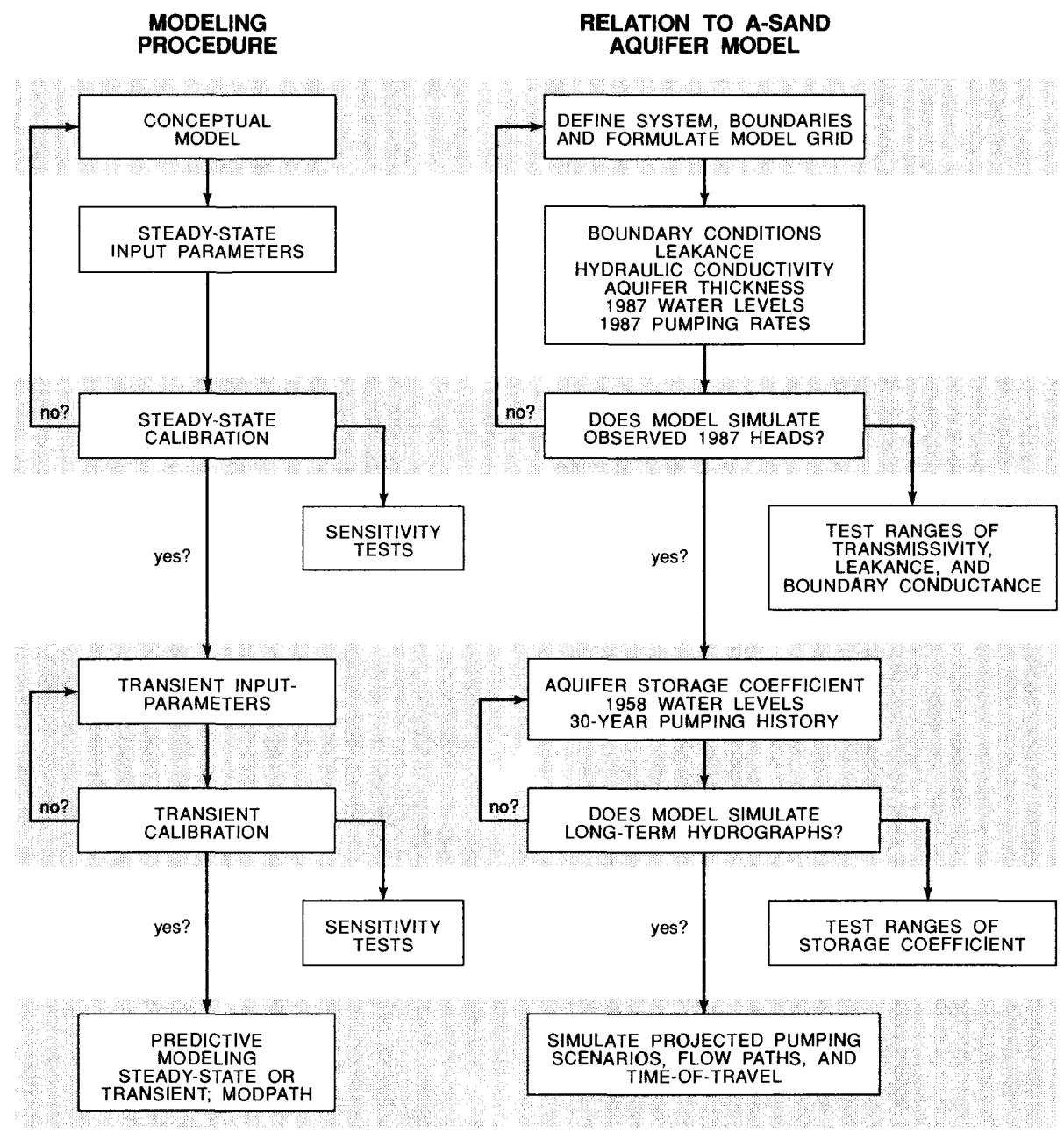

Figure 9.- Modeling procedures and their relation to the A-Sand aquifer model. 
Table 2.—Model-input parameters

[m, meter; $(\mathrm{m} / \mathrm{d}) / \mathrm{m}$, meter per day per meter; $\mathrm{m} / \mathrm{d}$, meter per day; $\mathrm{m}^{3} / \mathrm{d}$, cubic meter per day; $\mathrm{m}^{2} / \mathrm{d}$, square meter per day; SWM, Suriname Water Company; DWV, Water Supply Service, Ministry of National Resources and Energy]

\begin{tabular}{|c|c|c|}
\hline Parameter & Value(s) & Source of values \\
\hline \multicolumn{3}{|l|}{ 1. Steady-state calibration } \\
\hline 1987 starting heads & $\begin{array}{l}1.7 \text { to } 13.0 \mathrm{~m} \\
\text { below sea level }\end{array}$ & $\begin{array}{l}\text { Map prepared from measurements in } 14 \\
\text { A-Sand aquifer observation wells (fig. 5). }\end{array}$ \\
\hline Leakance coefficient & $0.0000015(\mathrm{~m} / \mathrm{d}) / \mathrm{m}$ & $\begin{array}{l}\text { Estimated from hydraulic conductivity ranges for } \\
\text { unweathered marine clays (Freeze and Cherry, } \\
\text { 1979, p. 29). }\end{array}$ \\
\hline Hydraulic conductivity & $90 \mathrm{~m} / \mathrm{d}$ & $\begin{array}{l}\text { Estimated from range of values between } 12 \text { and } \\
340 \mathrm{~m} / \mathrm{d} \text { (United Nations Development } \\
\text { Programme, 1972, p. } 42 \text {; Mente, } 1984, \text { p. } 56 \text { ). }\end{array}$ \\
\hline Aquifer thickness & 2 to $50 \mathrm{~m}$ & $\begin{array}{l}\text { Estimated from map by United Nations Develop- } \\
\text { ment Programme (1972, fig. III-3). }\end{array}$ \\
\hline 1987 pumping rates & 1,926 to $19,059 \mathrm{~m} /{ }^{3} \mathrm{~d}$ & Provided by SWM and DWV (see table 1). \\
\hline Boundary conductances & 12 to $270 \mathrm{~m}^{2} / \mathrm{d}$ & Derived through model calibration. \\
\hline \multicolumn{3}{|l|}{ 2. Transient calibration } \\
\hline Predevelopment starting heads & $3 \mathrm{~m}$ above sea level & $\begin{array}{l}\text { Estimated from measurements in six wells } \\
\text { (United Nations Development Programme, } \\
\text { 1972, Annexes } 2 \text { and 3). }\end{array}$ \\
\hline Specific storage & $0.0000 \mathrm{I} / \mathrm{m}$ & $\begin{array}{l}\text { Estimated from aquifer tests (United Nations } \\
\text { Development Programme, 1972, figs. III } 44 \\
\text { and III 45). }\end{array}$ \\
\hline $1958-87$ total pumping rates & 1,643 to $40,230 \mathrm{~m}^{3} / \mathrm{d}$ & Provided by SWM and DWV (see table 1). \\
\hline \multicolumn{3}{|l|}{ 3. Predictive model } \\
\hline 1987 simulated starting heads & $\begin{array}{l}1.8 \text { to } 14.4 \mathrm{~m} \\
\text { below sea level }\end{array}$ & Output from steady-state calibration. \\
\hline 1987 pumping rates & See above & See above. \\
\hline
\end{tabular}

to zero, simulated heads were lower than observed heads. A separate calibration was made whereby boundary conductances were increased 50 percent to allow 50 percent more inflow under the same head conditions as in the leaky calibration. Transmissivity, however, needed to be raised only about 20 percent to convey water from the north coast to the pumping centers. A nonleaky calibration was achieved with little effort. However, the conceptualized leaky system with lower transmissivity is considered more realistic because the overlying and underlying units are known to contain sandy beds as well as clay units. Because the model is sensitive to changes in the aquifer transmissivity and confining unit leakance, a program of field testing to refine estimates of hydraulic properties and to map heads in bounding aquifers would benefit any updating of the model.

\section{Transient Calibration}

A transient simulation incorporated the 30-year pumping history (table 1). A specific storage value of 0.00001 per meter was specified initially and the model computed the storage coefficient for each grid block by multiplying the value by the aquifer thickness in each block. Other input files were changed to accommodate transient conditions according to guidelines by McDonald and Harbaugh (1988). The transient calibration was achieved by adjusting specific storage until simulated heads matched measured heads at long-term observation wells. Adjustments of transmissivity or leakance were not done because this would have required recalibration of the steady-state model. Figure 11 compares water-level hydrographs that were simulated by the transient model at specific grid blocks with measurements made in three long-term observation wells located within the blocks. Simulated levels are generally within 2 meters of observed levels over the 30 -year time period.

A conclusion drawn from the transient calibration is that the system reaches steady state in less than 1 year. Evidence for this is the flattening of the observed waterlevel hydrographs in consecutive years where pumping is stable (fig. 4). The computed storage coefficient ranges between 0.00002 and 0.00055 , which indicates low aquifer storage. Sensitivity tests indicated that, when specific storage is increased by a factor of 10 , 
water levels varied from calibration levels by about 0.1 meter, which indicates that the model is insensitive to the storage parameter when such low values are used in combination with relatively large year-long time steps. Further testing of the model with 1-day time steps and 1987 pumpage revealed that equilibrium is reached within a few days. The transient calibration is essentially a series of 30 steady-state simulations. This principle facilitates model runs because a steady-state model using average annual pumpage will simulate the same head distribution in one time step as it will at the end of a transient run with many time steps, thereby saving computer time.

\section{Methodologies for Model Improvement}

The model of the A-Sand aquifer is only as accurate as the data on which it is based. Statistically, the model accurately matches observed conditions. However, the model is based on a sparse data set that could be improved by:
1. Conducting long-term (5-day or more) aquifer tests at each well field. This could be accomplished whenever a new well goes online. The procedure would involve shutting down one or two A-Sand aquifer production wells and using them for observation; obtaining 2 or more days of periodic background measurements to ensure that water levels have stabilized; pumping the new well and taking periodic measurements of water levels and pumping rates; and analyzing drawdown data for transmissivity, storage coefficient, and leakance coefficient. Ideally, observation wells could be installed in overlying and underlying aquifers to estimate the importance of vertical leakage in the ground-water system and possibly to compute leakance coefficients.

2. Keeping more accurate records of water-level measurements. Elevations of measuring points are based on old data and are questionable. Wells at Zorg en Hoop and Helena Christina have not been

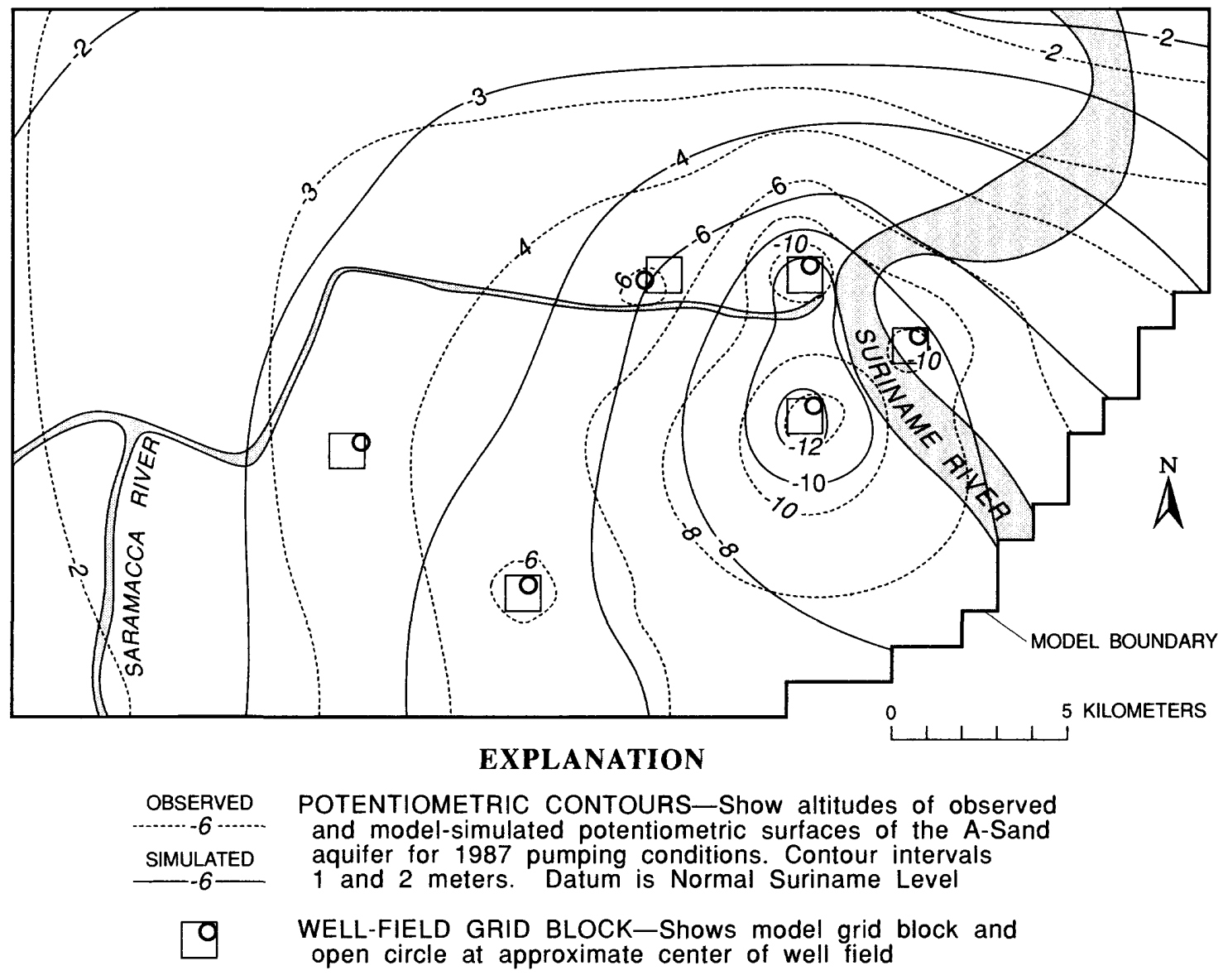

Figure 10.-Observed and simulated potentiometric surfaces of the A-Sand aquifer, 1987 , for the steady-state calibration. 


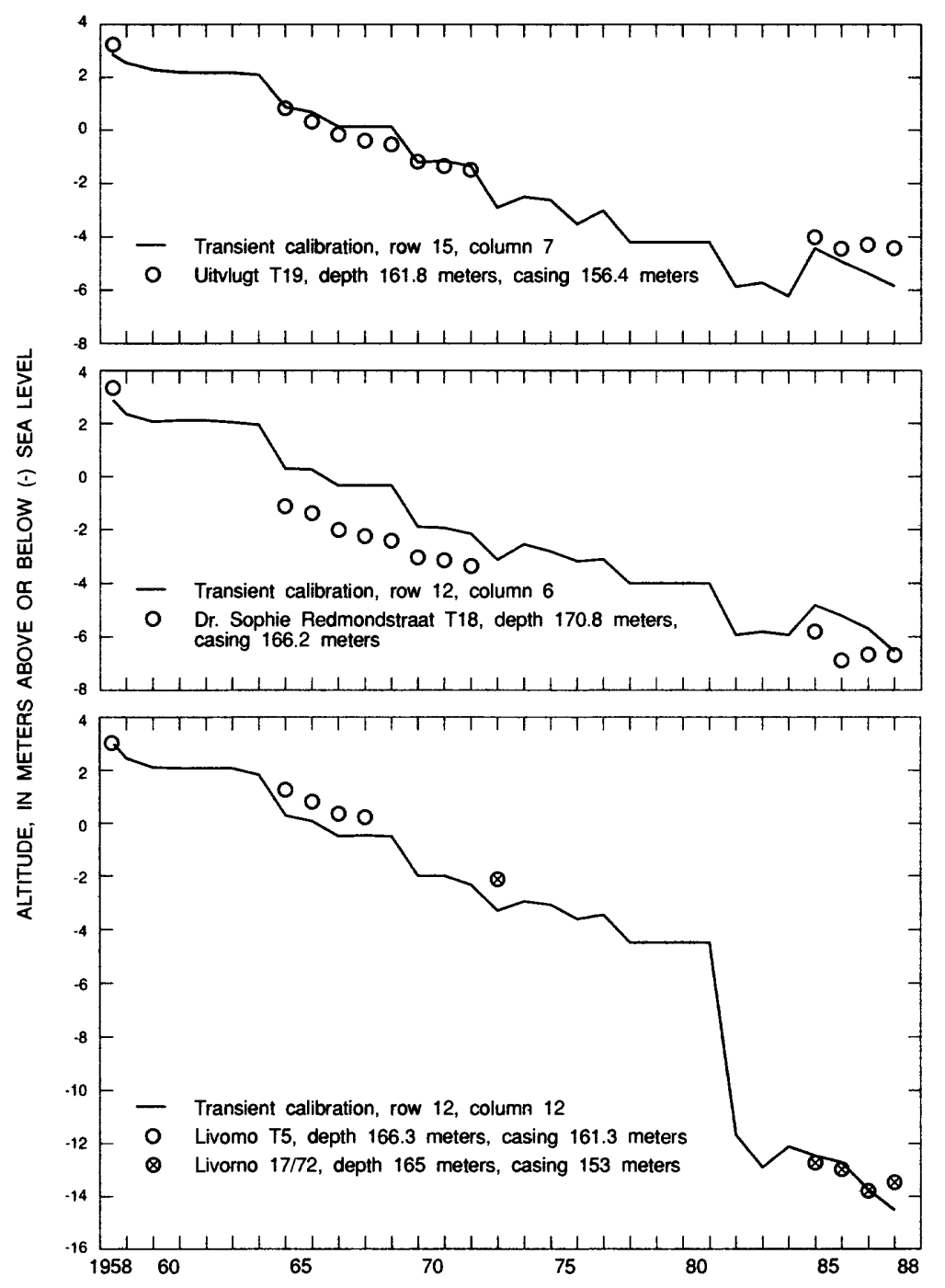

Figure 11.-Observed and simulated water levels in the A-Sand aquifer, 1958-87, for the transient calibration.

surveyed with reference to sea level. Changes in a measuring point, such as at the Garnizoenspad well in row 31, column 4 (fig. 5), need to be documented. A critical observation well at Uitkijk in row 31 , column 12 , has been destroyed and should be replaced.

- Gaining a better understanding of the transition zone between saltwater and freshwater. Saltwater encroachment threatens the life expectancy of well fields at Leysweg, Zorg en Hoop, and Meerzorg. A program of test drilling to define the transition zone and the installation of long-term waterquality monitoring wells would benefit future studies. Chloride concentrations in water from the Dr. Sophie Redmondstraat well do not seem to be changing, even though the well is located between the interface and Zorg en Hoop where the water quality is changing. Construction of the well and the sampling procedures need to be checked to ensure that a representative sample from the A-Sand aquifer is being obtained.

4. Monitoring the Coesewijne and Onverdacht aquifer systems. Mente (1984, fig. 9) proposed that an observation-well network be installed in the Coesewijne aquifer system, but as of 1988, a regular water-level and water-quality monitoring program had not been instituted. Water-level observation wells, especially in the Livorno area where there are no Coesewijne aquifer production wells, would provide information on leakage between the Coesewijne aquifer system and A-Sand aquifer. Monitoring the Coesewijne and Onverdacht aquifer systems also would test the hypothesis of constant-head conditions in the aquifers and whether the head values used in the model are reasonable. 


\section{SIMULATING EFFECTS OF PUMPAGE ON AQUIFER HEADS AND GROUND-WATER MOVEMENT}

The numerical model can be used to simulate the head distribution and water budget in the A-Sand aquifer that would result from a hypothetical stress on the hydrologic system. Thus, model results may be helpful to government agencies, consulting engineers, and planners as a management tool in the development of water supplies. Typical examples are presented to demonstrate how model results can be used to estimate:

1. Historical water-level conditions,

2. Effects of pumping from a new well field,

3. Effects of redistributing pumpage by adding a new well field to relieve overpumping at existing well fields, and

4. Ground-water flow velocity and the potential for inland movement of saltwater.

Although these four cases are described in detail, there are many alternatives that can, and some that cannot, be tested. For example, the model could be used to simulate the effects on leakage to the A-Sand aquifer due to lowering the head in the Coesewijne aquifer. It also could be used to demonstrate how a line of injection or withdrawal wells along the north coast might be utilized to reduce head gradients, thereby slowing saltwater encroachment. Because of the relatively large grid, the model cannot be used to simulate interference between wells within a well field. Hydrologic judgement should be used when simulating pumpage near the model boundaries.

\section{Historical Head Conditions}

Little is known about the shape of the potentiometric surface of the A-Sand aquifer prior to 1985. Head measurements were made when the first test wells were constructed in the 1950's and again as new wells were constructed in the late 1960's and early 1970's. The A-Sand aquifer observation well network was not instituted until 1985. The transient model was used to simulate head conditions each year between 1958 and 1987. The results illustrate how increased pumping has lowered the potentiometric surface from its predevelopment head of 3 meters above sea level to the 1987 heads. Figure 12 shows simulated potentiometric-surface maps at the end of 1960,1965, 1970, 1975, 1980, 1985, and 1987. Maps derived from simulation for these and intervening years were used to estimate annual changes in hydraulic gradient and rate of landward movement of the saltwater-freshwater transition zone north of the Zorg en Hoop well field.
1960. - Combined pumping from Santo Boma and Zorg en Hoop well fields was $3,288 \mathrm{~m}^{3} / \mathrm{d}$, and cones of depression had developed around each well field. The lowest point occurred within the $1 \mathrm{~km}^{2}$ grid block at Zorg en Hoop where the head at the end of 1960 was about 1.3 meters above sea level. The head in the Santo Boma grid block was 2.1 meters above sea level and was about 0.1 meter below the level in surrounding grid blocks. The water balance indicates that pumpage was derived from vertical leakage ( 21 percent) and boundary inflow (79 percent) and that $365 \mathrm{~m}^{3} / \mathrm{d}$ of water was lost as upward leakage to the Coesewijne aquifer. The system was in near equilibrium, as indicated by an average change in storage of $37 \mathrm{~m}^{3} / \mathrm{d}$.

1965.-Combined pumping from Santo Boma, Zorg en Hoop, and Meerzorg well fields was $9,862 \mathrm{~m}^{3} / \mathrm{d}$. The cone of depression around Zorg en Hoop masked any head declines caused by pumping at Meerzorg. The potentiometric surface at Zorg en Hoop had declined to 2.2 meters below sea level and was below sea level over an $18-\mathrm{km}^{2}$ area. Upward leakage to the Coesewijne aquifer system had ceased, and 72 percent of the pumpage was derived from boundary inflow and 28 percent from vertical leakage. Less than 1 percent of the pumped water was derived from storage.

1970. - Combined pumping from Santo Boma, Zorg en Hoop, Meerzorg, and Koewarasan well fields was $18,082 \mathrm{~m}^{3} / \mathrm{d}$. A cone of depression was centered at Zorg en Hoop, which was producing 94 percent of the water. The center of the cone was about 6.5 meters below sea level, and the potentiometric surface was below sea level over a $251-\mathrm{km}^{2}$ area. Seventy percent of the pumped water was derived from boundary inflow and 30 percent from leakage. The average reduction in storage of $32 \mathrm{~m}^{3} / \mathrm{d}$ is about three-tenths of 1 percent of the pumpage.

1975. - Combined pumping from the Zorg en Hoop, Meerzorg, Koewarasan, and Leysweg well fields was $24,931 \mathrm{~m}^{3} / \mathrm{d}$. Dual coalescing cones of depression had developed in the Leysweg-Zorg en Hoop area. The lowest head was 7.7 meters below sea level at Zorg en Hoop. The potentiometric surface had been lowered below sea level throughout the active model area of $619 \mathrm{~km}^{2}$ and was below 5 meters in a $4-\mathrm{km}^{2}$ area. Seventy percent of the pumped water was derived from boundary inflow and 30 percent from leakage. The average reduction in storage of $137 \mathrm{~m}^{3} / \mathrm{d}$ was about six-tenths of 1 percent of the pumpage. 

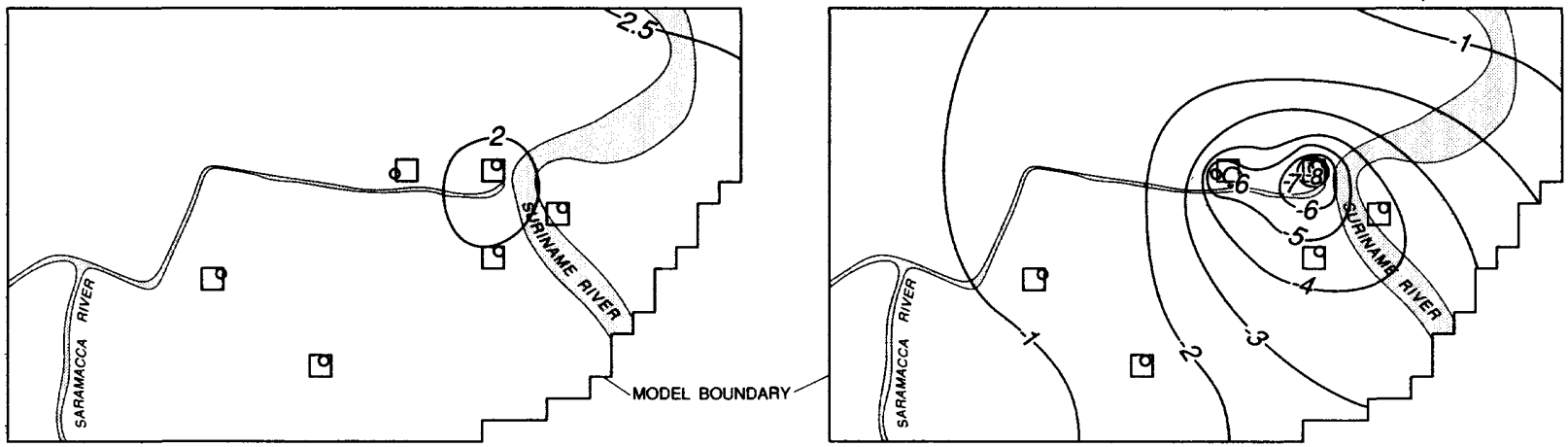

PUMPING $9,862 \mathrm{M}^{3} / \mathrm{D}$
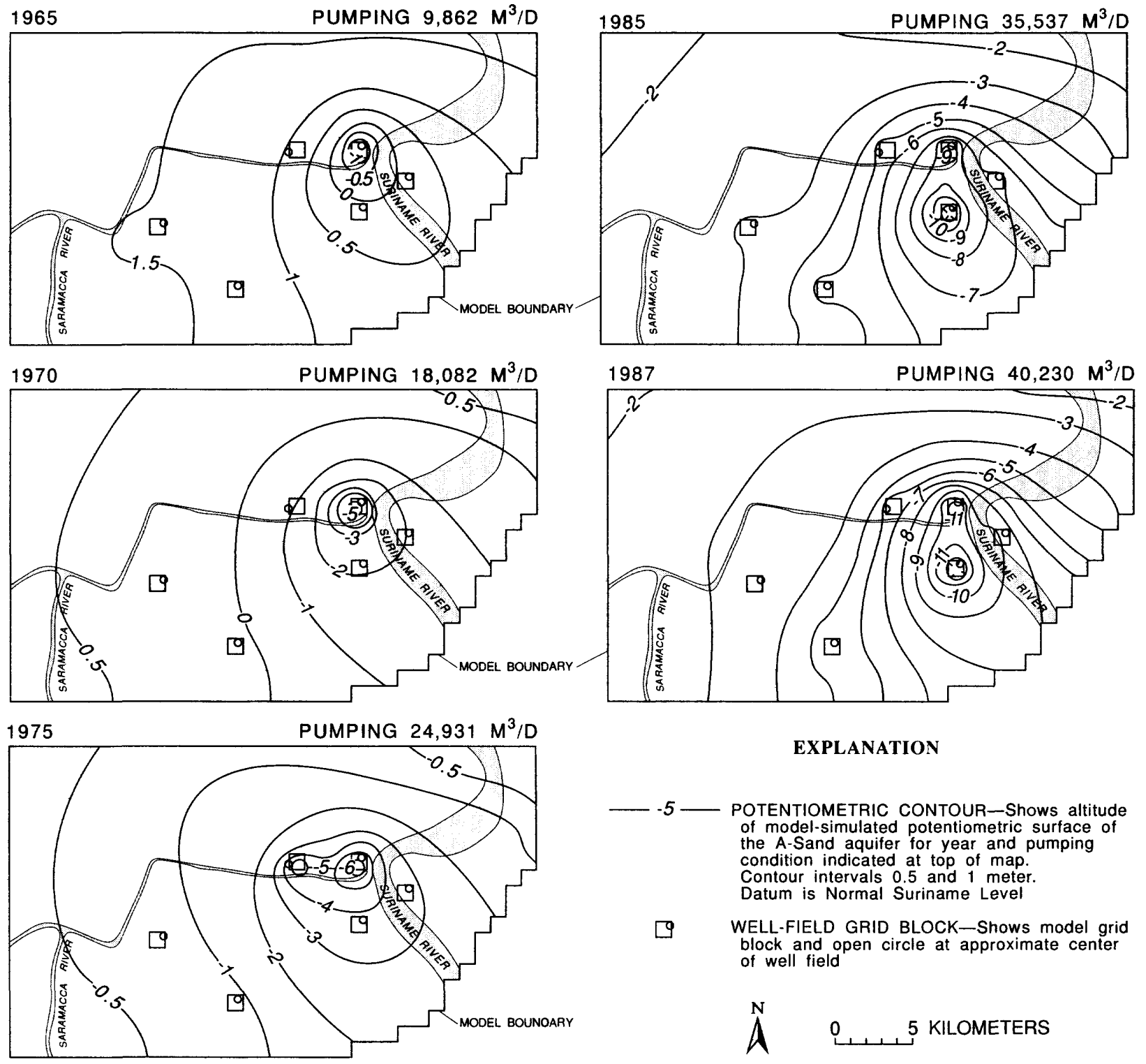

Figure 12.-Simulated potentiometric surface of the A-Sand aquifer for 1960, 1965, 1970, 1975, 1980, 1985, and 1987. 
1980.-Combined pumping from the Zorg en Hoop, Meerzorg, Koewarasan, and Leysweg well fields was $28,013 \mathrm{~m}^{3} / \mathrm{d}$. The lowest head was 9.1 meters below sea level at Zorg en Hoop and was more than 5 meters below sea level over an $18-\mathrm{km}^{2}$ area around the well field. Again, 70 percent of the pumped water was derived from boundary inflow, 30 percent from leakage, and there was little storage change.

1985.-Combined pumping from Zorg en Hoop, Meerzorg, Koewarasan, Leysweg, Livorno, and Helena Christina well fields was $35,537 \mathrm{~m}^{3} / \mathrm{d}$. Leysweg pumpage had been reduced, and a dual coalescing cone of depression was established in the Zorg en Hoop-Livorno area. The lowest head was 12.6 meters below sea level at Livorno, and the depression of 5 meters or more below sea level had expanded to an area of $168 \mathrm{~km}^{2}$. The imaging effect of the no-flow boundary probably caused significant distortion of the cone southeast of Livorno. The large drawdown at Livorno resulted in a small change in the water balance. About 66 percent of the pumpage was derived from boundary inflow, 34 percent from leakage, and less than 0.1 percent from storage.

1987.-Combined pumping from the six active well fields was $40,230 \mathrm{~m}^{3} / \mathrm{d}$. The lowest head of 14.4 meters below sea level occurred at Livorno, and at Zorg en Hoop, the level was 12.9 meters below sea level. Heads were more than 5 meters below sea level throughout a $200-\mathrm{km}^{2}$ area that encompassed Leysweg, Meerzorg, Zorg en Hoop, Livorno, and Helena Christina. About 67 percent of the pumped water was derived from boundary flow, 33 percent from leakage, and there was little change in aquifer storage.

\section{Pumping from a New Well Field}

A steady-state simulation was made to demonstrate how the model can be used to assess the potential effects of pumping from a hypothetical new well field $4 \mathrm{~km}$ northeast of Koewarasan in the grid block delineated by row 22 and column 10 (fig. 13). The site is in an area

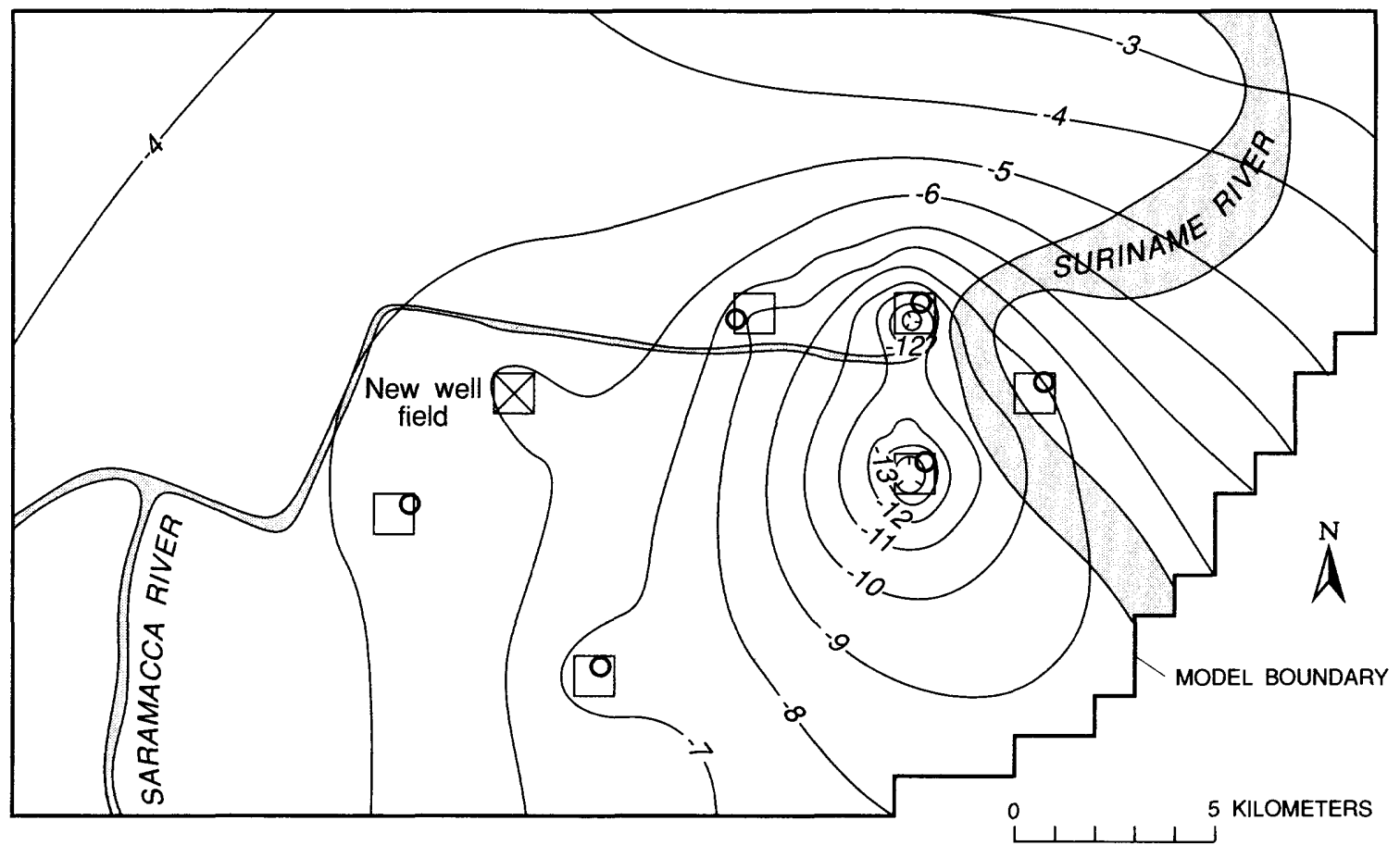

EXPLANATION

- -7- POTENTIOMETRIC CONTOUR-Shows altitude of the simulated potentiometric surface of the A-Sand aquifer with a hypothetical new well field in operation

9 WELL-FIELD GRID BLOCK-Shows model grid block and open circle at approximate center of well field. Hypothetical new well field withdraws 6,000 cubic meters per day

Figure 13.- Simulated steady-state potentiometric surface of the A-Sand aquifer when a hypothetical new 6,000-cubic-meters-per-day well field is added to existing well fields. 
where the ground water potentially is high in chloride; hence, the simulation should be construed only as an example. The assigned pumping rate was $6,000 \mathrm{~m}^{3} / \mathrm{d}$.

Figure 13 shows the simulated potentiometric surface of the A-Sand aquifer with combined pumping from the one new and six existing well fields that totals 46,230 $\mathrm{m}^{3} / \mathrm{d}$. Figure 14 shows the head change that would occur with respect to the 1987 potentiometric surface. The potentiometric surface would be lowered throughout the modeled area; however, a deep cone of depression, such as that observed at Livorno, would not develop around the new well field. This is because the new well field is in an area where the aquifer is relatively thick; hence, modeled transmissivity of $2,250 \mathrm{~m}^{2} / \mathrm{d}$ is relatively high, and inflow from the north is not diverted to other pumping centers. The head would be lowered 3.1 meters in the new well-field grid block. The lowest head would still occur at Livorno where a simulated head of 15.2 meters below sea level represents a decline of 0.8 meter below the 1987 level. Heads would be more than 5 meters below sea level throughout a $312-\mathrm{km}^{2}$ area.
At equilibrium, approximately 66 percent of the pumped water would be derived from boundary flow and 34 percent from leakage.

If the new well field were placed farther to the south toward the impermeable boundary (aquifer pinchout), it is anticipated that drawdown would be greater than in the example simulation. Less water would be drawn in from the north and more water would be derived from vertical leakage.

\section{Redistributing 1987 Pumpage}

In 1987, the pumping rate from the A-Sand aquifer was $40,230 \mathrm{~m}^{3} / \mathrm{d}$ and was at an all-time high rate. Consequently, the potentiometric surface had declined to record low levels. At Zorg en Hoop and Livorno well fields, water levels were about 12 and 14 meters below sea level, respectively. Interference among closely spaced wells had reduced pumping rates of individual wells, increased power consumption, required lowering of some pump intakes, and increased the gradient from the north where the aquifer contains poor quality water.

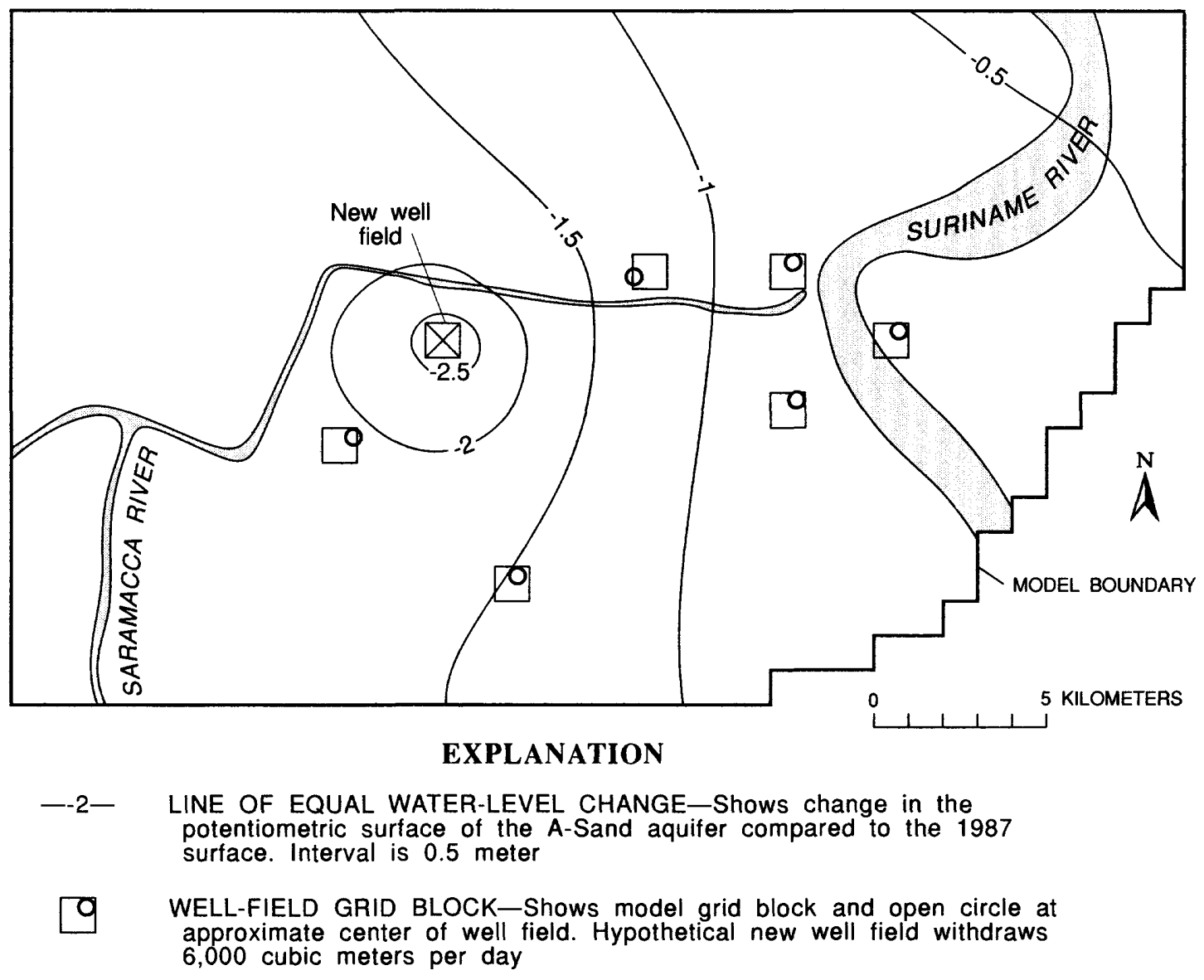

Figure 14.- Simulated head change with respect to the 1987 potentiometric surface when a hypothetical new 6,000 -cubicmeters-per-day well field is added to existing well fields. 
The aquifer model was used to assess how redistributing pumpage might relieve large drawdowns at the two well fields. A steady-state model simulation was made with a hypothetical new $6,000-\mathrm{m}^{3} / \mathrm{d}$ well field at row 22 and column 10 (fig. 15), as described in the previous example. Pumpages at Zorg en Hoop and Livorno, however, were reduced by $5,988 \mathrm{~m}^{3} / \mathrm{d}$, or 20 percent below 1987 levels. The resultant modelsimulated potentiometric-surface and head-change maps are shown in figures 15 and 16 , respectively.

With the pumpage redistributed, the cone of depression in the potentiometric surface would be broader and shallower than in 1987. Heads would be more than 5 meters below sea level throughout a $217-\mathrm{km}^{2}$ area. One to 2 meters of rise would occur at Zorg en Hoop, Livorno, and Meerzorg, and there would be no effect at Leysweg. The north-south head gradient within $2 \mathrm{~km}$ of Zorg en Hoop would be reduced to $2.6 \mathrm{~m} / \mathrm{km}$ from a gradient of $3.2 \mathrm{~m} / \mathrm{km}$ in 1987 . About 66 percent of the pumped water would be derived from boundary flow and 34 percent from leakage.

\section{Estimating the Rate of Saltwater Encroachment}

A transition zone between saltwater and freshwater occurs in the A-Sand aquifer north and east of the well-field areas and possibly to the west along the southeast Bakhuis fault. Under the assumption that the zone moves toward the pumping centers by advective transport (at the same velocity as ground-water flow, $\bar{v}$ ), the rate of saltwater encroachment can be calculated by rearranging equation 1

$$
\bar{v}=\frac{K}{n} \cdot \frac{\Delta h}{l}
$$

The model can be used to obtain the head difference between points in the study area. Equation 2 can be used to calculate the velocity of ground-water flow between points on a flow path that is drawn perpendicular to the potentiometric-surface contours. If the two points are a well field and a saltwater-freshwater transition zone, the velocity can be used to calculate time-of-travel from the transition zone to the well field.

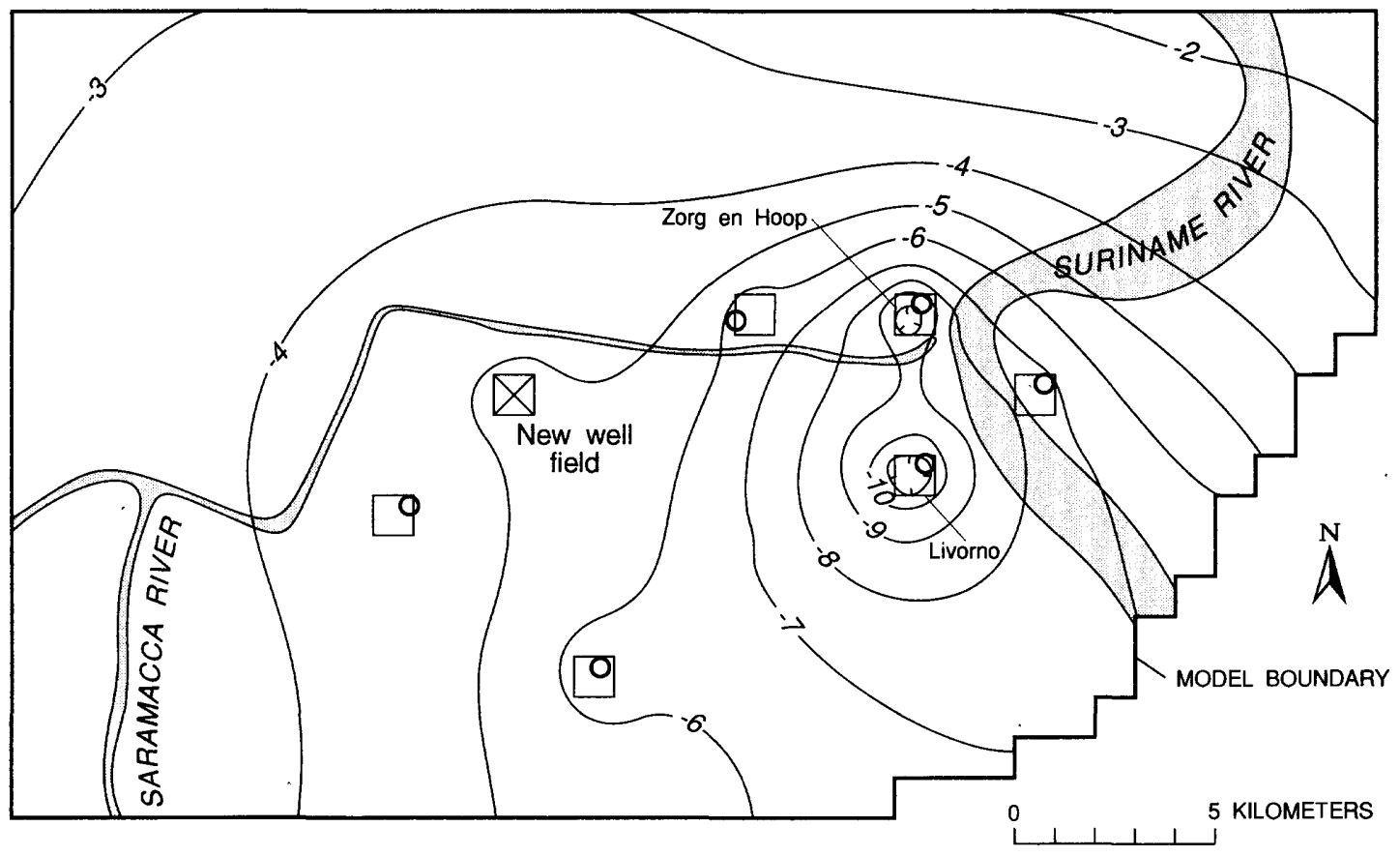

EXPLANATION

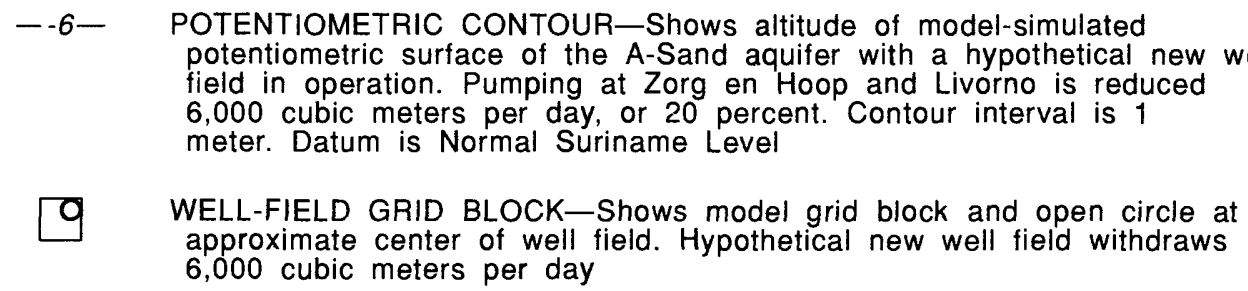

Figure 15.- Simulated steady-state potentiometric surface of the A-Sand aquifer when a hypothetical new 6,000-cubicmeters-per-day well field is added and pumpage from Zorg en Hoop and Livorno well fields is reduced 20 percent. 
An example of how the model can be used to assess the potential for saltwater encroachment is made on the basis of maps of the 1987 potentiometric surface (fig. 12) and the simulated potentiometric surface with pumping redistributed to a hypothetical new well field in relief of pumping at Zorg en Hoop and Livorno (fig. 15). If it is assumed that a high-chloride zone exists $4 \mathrm{~km}$ northwest of Zorg en Hoop, head differences between the high-chloride zone and the well field (based on the 1987 and the simulated pumpage redistribution potentiometric-surface maps) are 6.5 and 5.0 meters, respectively. Hydraulic conductivity from the model calibration is $90 \mathrm{~m} / \mathrm{d}$, and the estimated effective porosity is 0.21 . Ground-water flow velocities are calculated using equation 2 as follows:

$$
\begin{aligned}
& \overline{\mathrm{v}}_{1987}=\frac{90 \mathrm{~m} / \mathrm{d}}{0.21} \cdot \frac{6.5 \mathrm{~m}}{4,000 \mathrm{~m}}=0.70 \mathrm{~m} / \mathrm{d} \\
& \overline{\mathrm{v}}_{\text {redist }}=\frac{90 \mathrm{~m} / \mathrm{d}}{0.21} \cdot \frac{5.0 \mathrm{~m}}{4,000 \mathrm{~m}}=0.54 \mathrm{~m} / \mathrm{d} .
\end{aligned}
$$

The calculated time-of-travel from the hypothetical high-chloride zone to the well field is about 5,700 days under 1987 pumping conditions and 7,400 days with pumping redistributed to another well field. The estimated traveltime to the well field would be 15.7 years at the 1987 pumping condition and 20.3 years when pumping is redistributed.

\section{ASSESSMENT OF THE GROUND-WATER FLOW SYSTEM USING PARTICLE- TRACKING TECHNIQUES}

The use of particle-tracking techniques to generate flow pathlines and time-of-travel information from the results of numerical models can be extremely helpful in analyzing complex ground-water flow systems. The Modpath program (Pollock, 1989) is a particle-tracking postprocessing program designed for use with output from steady-state flow simulations obtained using the Modular model (McDonald and Harbaugh, 1988). Modpath can be used to delineate path lines and the position of particles at specified points in time.

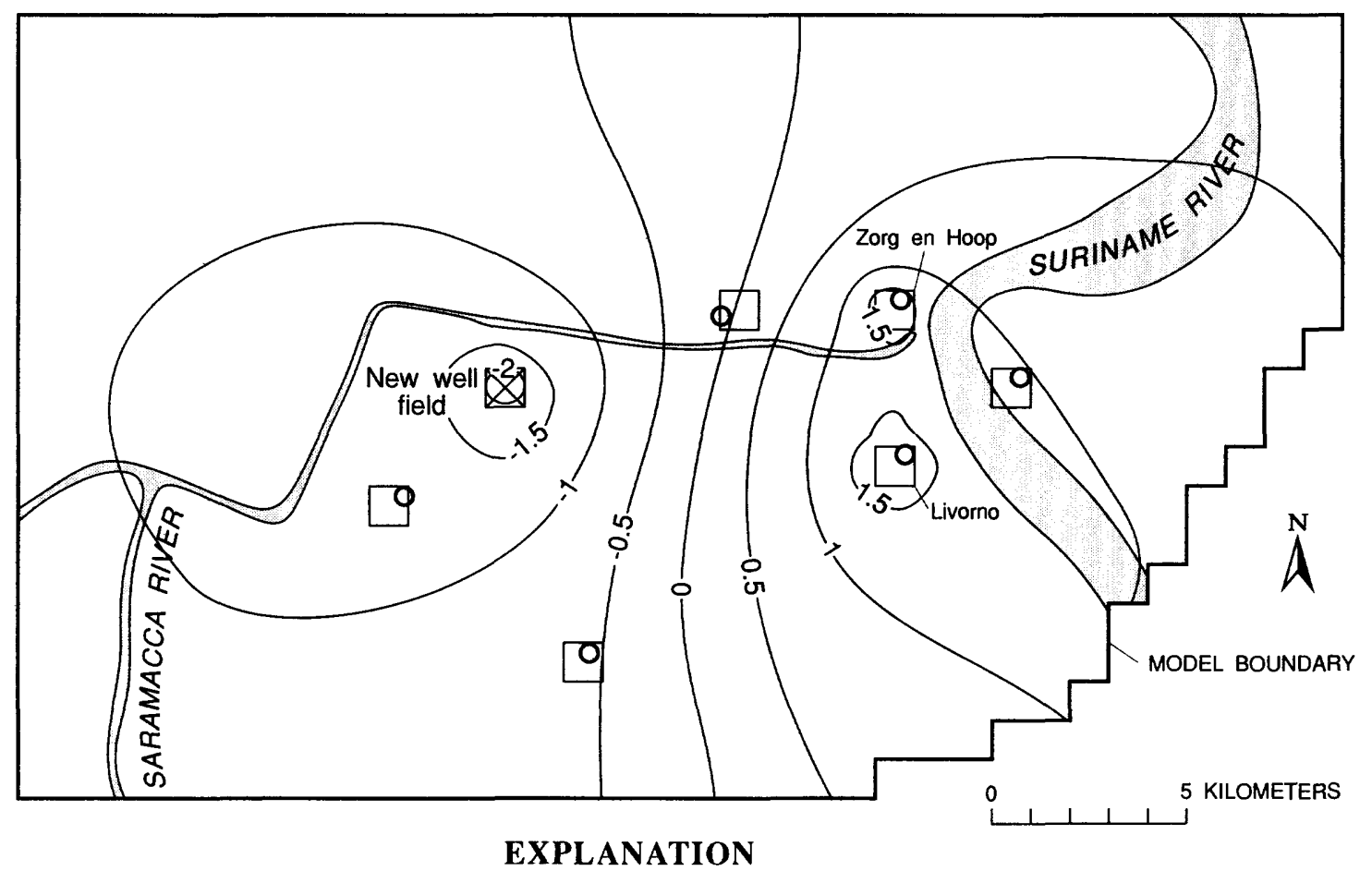

- -1- LINE OF EQUAL WATER-LEVEL CHANGE-Shows change in the potentiometric surface of the A-Sand aquifer compared to the 1987 surface. A hypothetical new well field is in operation, and pumping at Zorg en Hoop and Livorno is reduced by 6,000 cubic meters per day, or 20 percent. Interval is 0.5 meter

0 WELL-FIELD GRID BLOCK-Shows model grid block and open circle at approximate center of well field. Hypothetical new well field withdraws 6,000 cubic meters per day

Figure 16.- Simulated head change with respect to the 1987 potentiometric surface when a hypothetical new 6,000 -cubicmeters-per-day well field is added and pumpage from Zorg en Hoop and Livorno well fields is reduced 20 percent. 
Pathlines and particle positions can be tracked forward or backward in time from specified grid blocks. Particle-tracking is based on advective transport and cannot be used to compute solute concentrations in ground water because the method does not account for mixing.

Modpath was used to evaluate results of the previously described model runs as follows:

1. The backward-tracking mode was used to delineate pathlines and areas of well-field capture under 1987 pumping rates and when a new $6,000-\mathrm{m}^{3} / \mathrm{d}$ well field is added to existing well fields.

2. The forward-tracking mode was used to plot pathlines and time-of-travel of particles moving from the historical position of $300-\mathrm{mg} / \mathrm{L}$ chloride ground water toward the well fields under the 1958-86 average pumping rate. A second plot was made to predict movement from the 1986 simulated position of the high-chloride water to the well fields under modern pumping conditions represented by 1987 rates.

3. The backward-tracking mode was used to plot time-of-travel of particles captured by the well fields along selected pathlines under 1987 pumping rates.

\section{Pathlines and Areas of Well-Field Capture}

Figure 17 compares ground-water pathlines under the simulated head conditions for 1987 , which represent a $40,230-\mathrm{m}^{3} / \mathrm{d}$ pumping rate, and for 1987 with an additional $6,000-\mathrm{m}^{3} / \mathrm{d}$ well field. The maps were created by placing eight particles within each well-field grid block and then running the Modpath program in the backward-tracking mode to delineate pathlines along which ground water would flow. The area around each well field encompassed by the pathlines defines the approximate area of capture (within the boundaries of the modeled area) from which the well field draws its water.

The area of capture is not necessarily proportional to pumping rate, but is controlled by transmissivity of the aquifer and the proximity of each well field to the general head boundary. The Livorno and Helena Christina well fields are in an area of relatively low transmissivity and are far from the boundary; hence, they are characterized by large capture areas. The pathlines spread directly to the general head boundary nearest each well field, except for Livorno, which had a radial spread of pathlines. Much of the water leaking across the northern boundary is captured by the Leysweg, Zorg en Hoop, and Meerzorg well fields before it can reach Livorno. Livorno apparently derives pumpage from vertical leakage over a very large area and from some small areas along the general head boundary. This supports the hypothesis that the increase in chloride at Livorno is caused by vertical leakage rather than by inflow from the north. Zorg en Hoop accounts for nearly half the pumpage, yet its pathlines delineate a relatively small area of capture that leads directly to the general head boundary where water quality is poor. An observation well network along the pathlines could be used to monitor water-quality changes.

The addition of a $6,000-\mathrm{m}^{3} / \mathrm{d}$ hypothetical new well field in row 22 and column 10 would capture most of the flow in the northwest quadrant of the study area (fig. 17). Under 1987 pumping conditions, this water would have been captured by the Helena Christina, Koewarasan, Leysweg, and Livorno well fields. Almost all the water would be drawn from the direction of the southeast Bakhuis fault (fig. 6), which corresponds to an area suspected to contain water high in chloride. Shortduration pumping tests may indicate that the site is suitable for construction of a well field, but the model suggests that, over the long term, chloride concentration is likely to increase.

\section{Time-of-Travel for High-Chloride Ground Water}

Modpath was run to simulate time-of-travel from the historical position of the $300-\mathrm{mg} / \mathrm{L}$ line of equal chloride concentration toward the well fields under 1958-86 average pumping rates, which total 19,953 $\mathrm{m}^{3} / \mathrm{d}$ (table 1). This average period was chosen because pumping began in 1958 and chloride concentrations rose to $300 \mathrm{mg} / \mathrm{L}$ in some wells at the Leysweg and Zorg en Hoop well fields by 1986 . Although pumpage commenced at different times and increased at different rates in each well field, an average rate was considered to be representative because Leysweg and Zorg en Hoop were the dominant controls on the flow regime influencing the high-chloride ground water. It seems reasonable that, if the assumptions are correct, the predicted timeof-travel of the high-chloride water to the two well fields should be about 28 years.

Figure 18 shows the time-of-travel along selected pathlines from the position of the $300-\mathrm{mg} / \mathrm{L}$ line of equal chloride concentration. The plots were created by placing one particle in selected grid blocks along the estimated $300-\mathrm{mg} / \mathrm{L}$ chloride line shown in figure 6 . Modpath was then run in the forward-tracking mode with particle positions plotted at 5-year intervals over a period of 30 years. The lengths of the pathlines are proportional to the flow velocities. The westernmost pathline is the shortest, indicating that a particle moved less than $1 \mathrm{~km}$ in 30 years. Pathlines are truncated when they reach a well-field grid block. For example, a pathline that ends at the Leysweg well field is truncated 


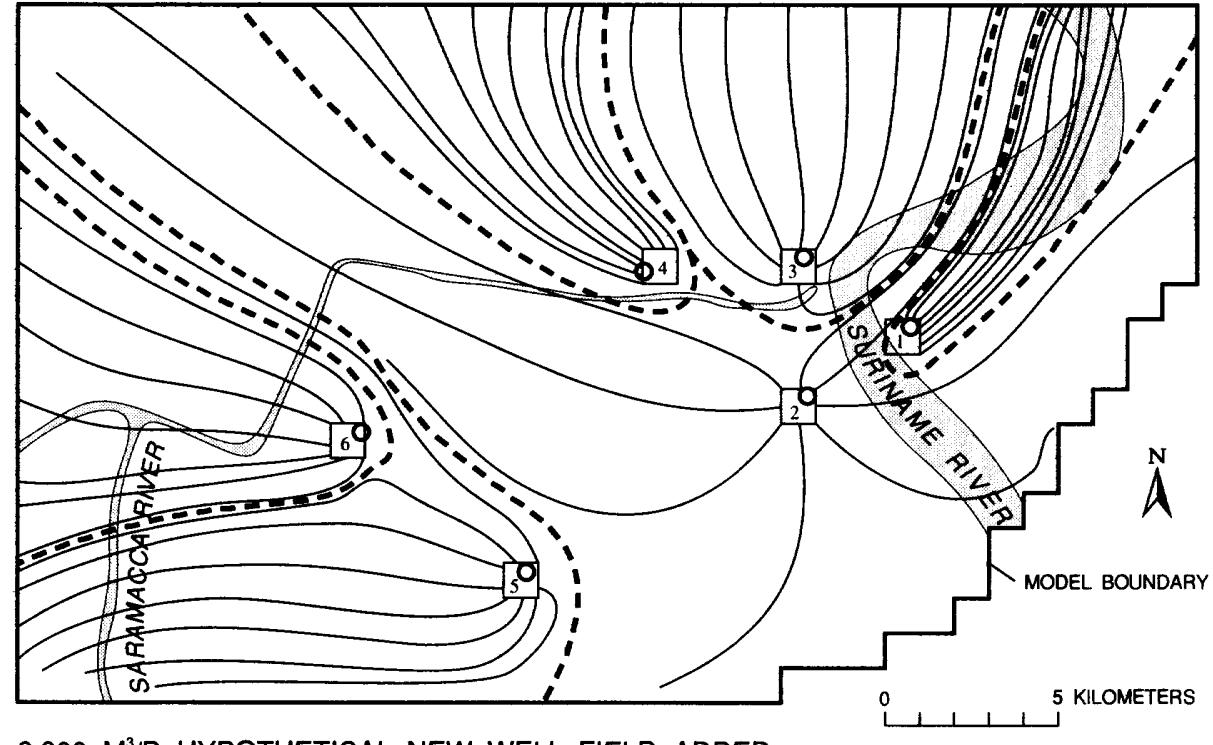

$6,000 \mathrm{M}^{3} / \mathrm{D}$ HYPOTHETICAL NEW WELL FIELD ADDED

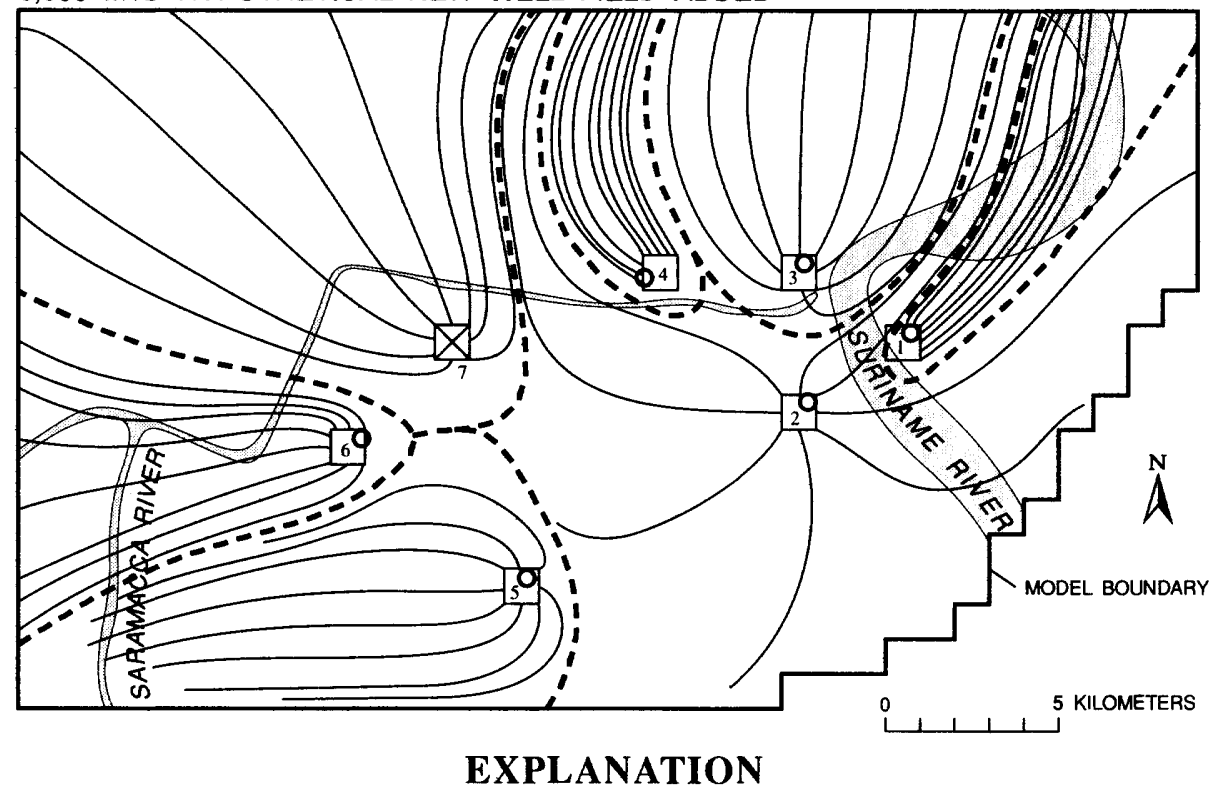

PATHLINE-Delineates ground-water flow path to the indicated well field. Dashed line encompassing pathline group is the approximate area for capture of each well field

WELL-FIELD GRID BLOCK-Shows model grid block and open circle at approximate center of well field

\begin{tabular}{lr} 
WELL FIELD & $\begin{array}{r}1987 \text { PUMPING } \\
\text { RATE (M }\end{array}$ \\
\hline 1. Meerzorg & 2,280 \\
2. Livorno & 10,877 \\
3. Zorg en Hoop & 19,059 \\
4. Leysweg & 3,538 \\
5. Helena Christina & 1,950 \\
6. Koewarasan & 1,926 \\
7. Hypothetical new well field & 6,000
\end{tabular}

Figure 17.-Pathlines of ground-water flow under 1987 pumping rates and when a hypothetical new 6,000-cubic-meters-per-day well field is added to existing well fields. 
shortly after the fourth arrowhead was plotted, indicating a time-of-travel for the high-chloride water of between 20 and 25 years. The simulated time-of-travel to the Zorg en Hoop well field is about 31 years. Given the uncertainties involved, including averaging pumpage from several wells up to 500 meters apart at the center of a grid block, estimating the position of the $300-\mathrm{mg} / \mathrm{L}$ chloride concentration line, the effects of vertical leakage and dispersion, and inhomogeneity of the aquifer system, the estimated time-of-travel is considered a reasonable representation of the observed time. Under this assumption, the simulated 1986 position of the $300-\mathrm{mg} / \mathrm{L}$ chloride concentration line was plotted.

The next step in predicting movement of high-chloride ground water was to place particles in grid blocks along the 1986 simulated position of the 300-mg/L chloride concentration line and plot pathlines and time-of-travel under 1987 pumping rates, which total $40,230 \mathrm{~m}^{3} / \mathrm{d}$ (table 1 ). The resulting time-of-travel

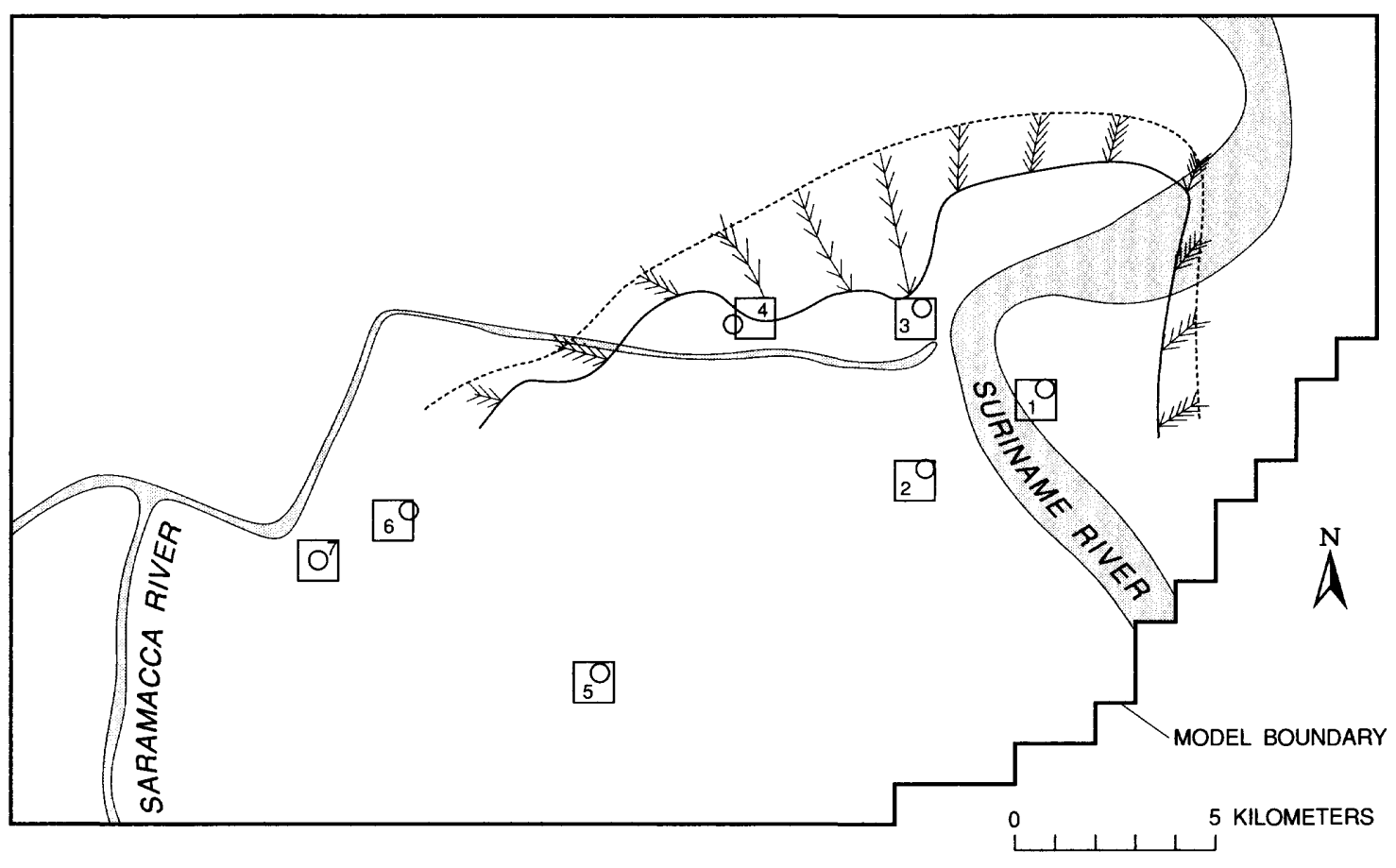

EXPLANATION

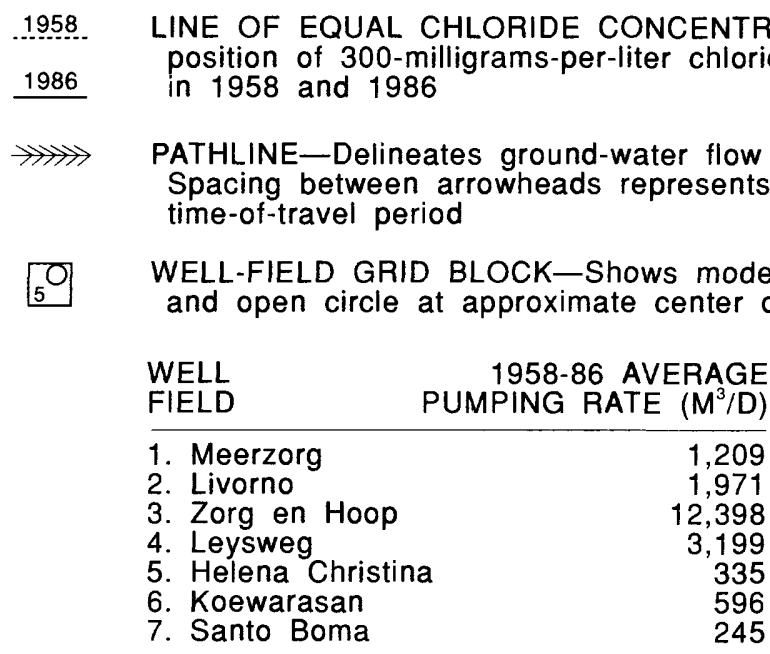

Figure 18.-Time-of-travel along selected pathlines from the 1958 historical position of the 300-milligramsper-liter line of equal chloride concentration for 30 years under 1958-86 average pumping rates. 
plots shown in figure 19 can be used to estimate when water-quality changes might occur at various well fields under modern rates of pumping. The positions of particles are shown at 10-year intervals. No pathlines lead from the area of high-chloride water to the Koewarasan and Helena Christina well fields, thereby indicating that these well fields should not be affected by saltwater intrusion from the coast. The increased chloride concentrations observed at Livorno well field during the 1980's support the hypothesis of vertical leakage to the A-Sand aquifer from overlying and underlying aquifer systems, which contain water of poor quality. Wells at Livorno should not experience lateral intrusion for at least 40 years under the 1987 pumping conditions. The plots also indicate that chloride concentrations at the Zorg en Hoop, Leysweg, and Meerzorg well fields will steadily increase as water in the A-Sand aquifer is replaced by inflow of high-chloride water from the north.

\section{Time-of-Travel to Well Fields}

Modpath was used to draw lines of equal time-of-travel to indicate the speed with which a contaminant (such as chloride) may move toward a well field under conditions of advective transport. Figure 20 shows the time-of-travel along selected pathlines to

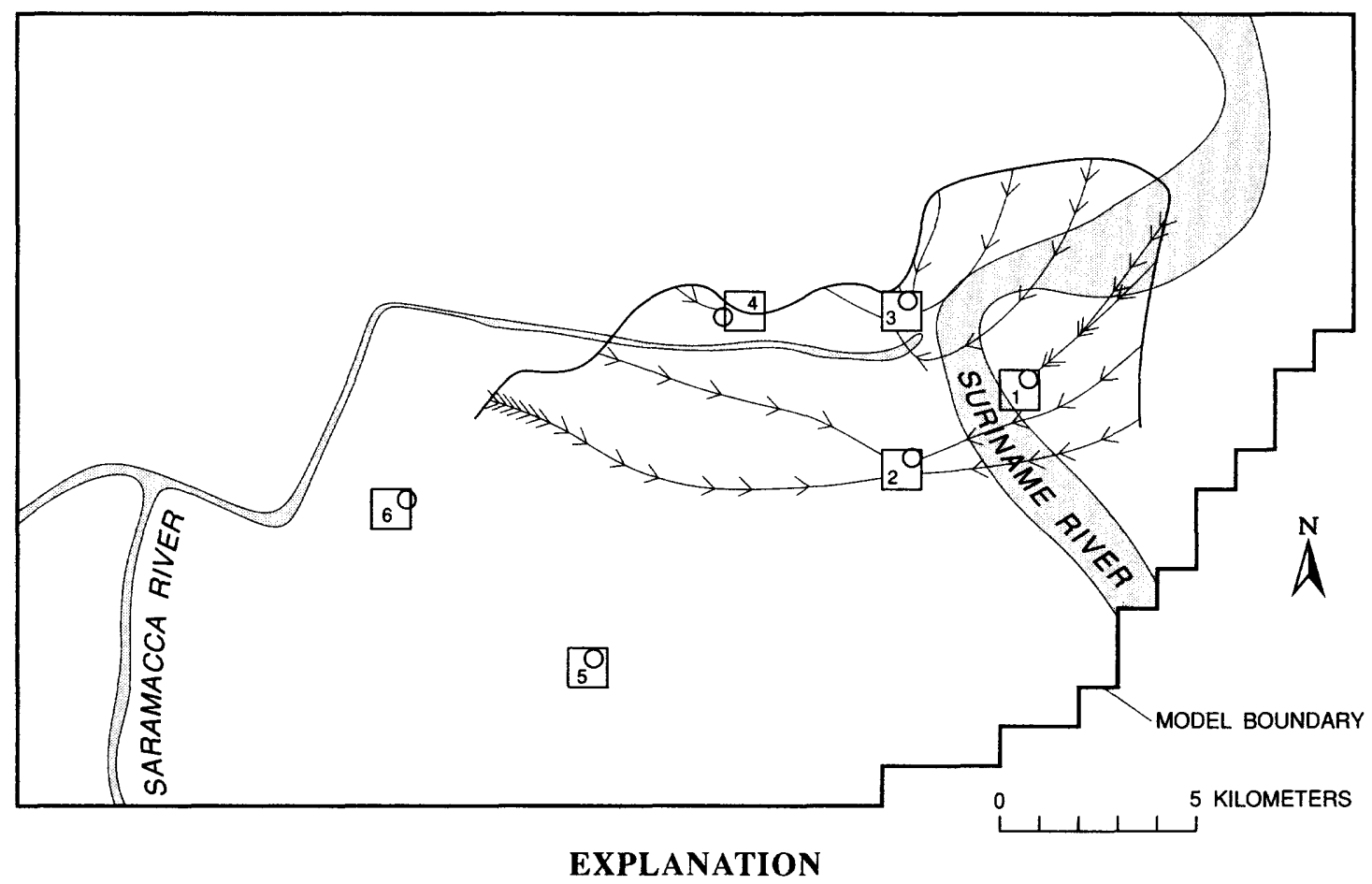

\begin{tabular}{|c|c|c|}
\hline & \multicolumn{2}{|c|}{$\begin{array}{l}\text { LINE OF EQUAL CHLORIDE CONCENTR } \\
\text { position of } 300 \text {-milligrams-per-liter chlori } \\
\text { in } 1986\end{array}$} \\
\hline$\ggg \ggg \ggg$ & \multicolumn{2}{|c|}{$\begin{array}{l}\text { PATHLINE-Delineates ground-water flow } \\
\text { Spacing between arrowheads represents } \\
\text { a } 10 \text {-year time-of-travel period }\end{array}$} \\
\hline \begin{tabular}{|l|} 
\\
5 \\
\end{tabular} & \multicolumn{2}{|c|}{$\begin{array}{l}\text { WELL-FIELD GRID BLOCK-Shows mod } \\
\text { and open circle at approximate center }\end{array}$} \\
\hline & $\begin{array}{l}\text { WELL } \\
\text { FIELD }\end{array}$ & $\begin{array}{l}1987 \text { PUMPING } \\
\text { RATE }\left(M^{3} / D\right)\end{array}$ \\
\hline & $\begin{array}{l}\text { 1. Meerzorg } \\
\text { 2. Livorno } \\
\text { 3. Zorg en Hoop } \\
\text { 4. Leysweg } \\
\text { 5. Helena Christina } \\
\text { 6. Koewarasan }\end{array}$ & $\begin{array}{r}2,880 \\
10,877 \\
19,059 \\
3,538 \\
1,950 \\
1,926\end{array}$ \\
\hline
\end{tabular}

Figure 19.-Time-of-travel along selected pathlines from the 1986 simulated position of the 300 -milligramsper-liter line of equal chloride concentration under 1987 pumping rates. 
each well field under the 1987 pumping condition. The plots were created by placing four particles within each well field and then running the Modpath program in the backward-tracking mode with particle positions plotted at 5-year intervals over a period of 30 years. The plots were utilized to estimate 5-, 10-, 15-, 20-, 25-, and 30-year times-of-travel.

The length of a pathline is proportional to the velocity of ground-water flow to a well field. The pathlines average about $4 \mathrm{~km}$ in length in the vicinity of the Livorno well field, indicating an average velocity of
$133 \mathrm{~m} / \mathrm{yr}$ within the zone of capture delineated by the 30-year time-of-travel line. The shortest pathlines are about $1 \mathrm{~km}$ in the vicinity of the Koewarasan well field, indicating an average velocity of $33 \mathrm{~m} / \mathrm{yr}$. Velocities increase as the particles approach the well fields, as indicated by progressively longer spacing between the positions of particles plotted at 5-year intervals along the pathlines.

The time-of-travel plots can be used to estimate movement of a contaminant. For example, if a test well were drilled $4 \mathrm{~km}$ north of the Zorg en Hoop well field

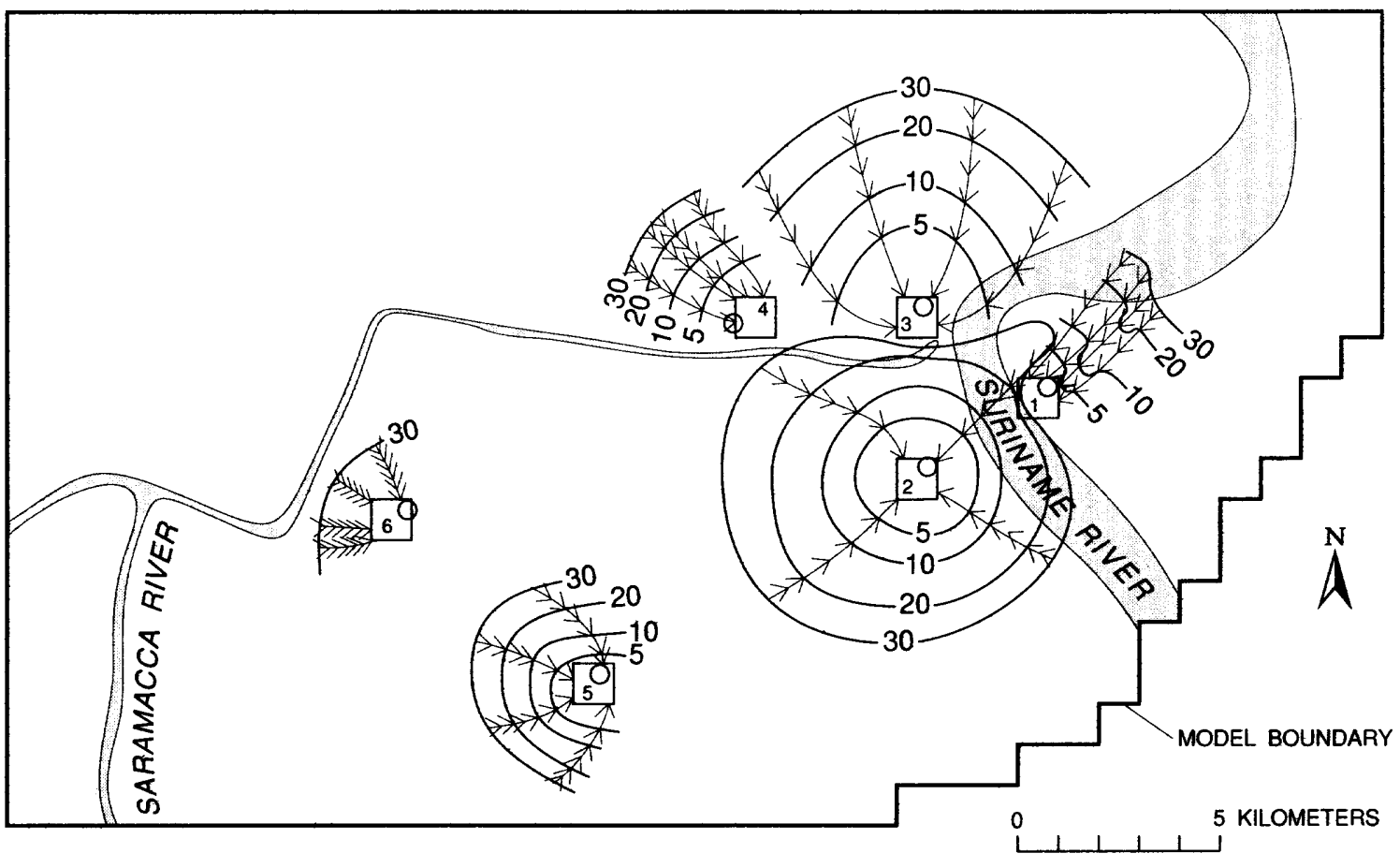

\section{EXPLANATION}

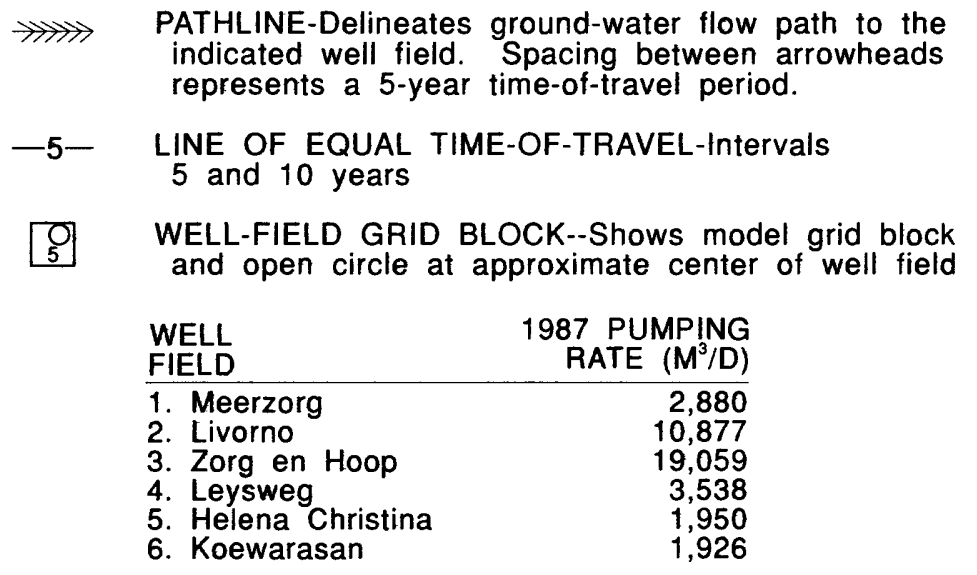

Figure 20.-Time-of-travel along selected ground-water pathlines to each well field for 30 years under 1987 pumping rates. 
and the water contained $1,000 \mathrm{mg} / \mathrm{L}$ of chloride, it could be expected to reach the well field in 20 years under 1987 pumping conditions. Another example supposes that the Suriname River floods and contaminated water pours down an abandoned well on the river's west bank near the Livorno well field. From figure 20, the estimated traveltime of contaminated water to the well field is between 7 and 30 years depending on the location of the abandoned well.

\section{LIMITATIONS OF THE MODEL APPLICATION}

A conceptual approach to ground-water modeling was used in the development of the A-Sand aquifer model. The hydrogeologic system was conceptualized, its hydraulic properties identified and estimated, and it was transformed into the mathematical analog. The numerical model approximates the physical processes that control ground-water flow, but it is only an approximate representation.

The hydrogeology has been simplified to the extent that an operational numerical model could be constructed. The mathematical solution is an approximate solution to the differential equations that define the system. Because it is not practical to track the movement of every drop of water in the system, the very localized effect of pumping small quantities of water may not be accurately simulated. Likewise, the effect of pumping large quantities of water near the edges of the model grid may not be accurately simulated because of inaccuracies in boundary assumptions.

Tests of the model's sensitivity to changes in hydraulic properties has indicated that there is no unique set of input data. The model could be calibrated over a rather broad range of values for leakance, hydraulic conductivity, and boundary conductance. The assumption of constant-head conditions above and below the A-Sand aquifer may be invalid in the vicinity of large well fields where deep cones of depression in the potentiometric surface of the A-Sand aquifer create a high potential for vertical leakage. Short-term aquifer tests indicate that the A-Sand aquifer is a complex system with highly variable hydraulic properties, yet the model was easily calibrated on the basis of uniform properties. Uncertainties, with respect to the aquifer-test data and the hydraulic properties of the confining units, would naturally be incorporated into the model. However, because the Modular model and Modpath program simulate head conditions and time-of-travel with reasonable accuracy, it is unlikely that a slightly different calibration would indicate different management strategies.

\section{SUMMARY AND CONCLUSIONS}

Thirty years of continuous increases in pumpage from the A-Sand aquifer at Paramaribo, Suriname, have created broad cones of depression that extend over hundreds of square kilometers. The Modular model was developed for a $619-\mathrm{km}^{2}$ area to help in understanding ground-water flow in the A-Sand aquifer, which is experiencing problems of well-field interference and encroachment of water high in chloride. Output from the flow model was used as input for the particletracking computer program, Modpath, to generate ground-water flow pathlines and time-of-travel information. The improved understanding of the ground-water system can aid in management of withdrawals from the aquifer.

The hydrogeologic system was simulated as three permeable layers separated by sandy clay confining units. The A-Sand aquifer is represented by the active middle layer, and the other layers are inactive constanthead sources of leakage. A no-flow boundary on the south coincides with impermeable crystalline rocks that truncate the A-Sand aquifer. A general-head boundary condition was applied on the west, north, and northeast where the aquifer continues beyond the model boundary. Boundary conductances are highest along the north boundary where the aquifer is thickest. A steady-state calibration was achieved when the simulated head accurately matched the measured 1987 head. A transient calibration reproduced observation-well hydrographs over a 30-year period.

Three simulations were made to demonstrate how the model could be used as a tool for water management. First, a transient simulation was made to assess water levels and sources of ground water during the period 1958 to 1987. Potentiometric surface maps for selected years show expanding and coalescing cones of depression as the number of well fields increased from one to six and pumping rates increased from 1,643 to $40,230 \mathrm{~m}^{3} / \mathrm{d}$. Next, a hypothetical new well field with a $6,000-\mathrm{m}^{3} / \mathrm{d}$ pumping rate was added to demonstrate how additional pumping would lower water levels at existing well fields. The simulation showed that water levels would be drawn down an additional 1 to 2 meters. Another demonstration redistributed pumping by adding the above new well field, but with an equivalent reduction in pumpage at the two most heavily pumped well fields, Zorg en Hoop and Livorno; water levels would rise 1 to 2 meters in the existing well fields under this simulation. Head gradients between Zorg en Hoop and the $300-\mathrm{mg} / \mathrm{L}$ line of equal chloride concentration were compared with 1987 gradients, and it was estimated that redistributing pumping would slow saltwater encroachment and perhaps extend the useful life of the well field by about 5 years. 
The understanding of the hydrogeology of the A-Sand aquifer was improved during development and testing of the model. Previous aquifer tests indicated considerable variability in hydraulic conductivity; however, an acceptable calibration was achieved using a constant value of $90 \mathrm{~m} / \mathrm{d}$. The system also previously had been conceptualized as having overlying and underlying impermeable beds with the only source of inflow being from the north. Although a calibration was achievable under assumed nonleaky conditions, the model produced reasonable results when it was assumed that approximately one-sixth of the water pumped originated as vertical leakage from each constant-head source aquifer system above and below the A-Sand aquifer. The transient model indicates that little water is withdrawn from storage in the thin, confined A-Sand aquifer.

The Modpath program was used in several ways to assess results of the Modular model simulations. First, it was used to delineate pathlines and approximate areas of well-field capture under 1987 pumping conditions and when a $6,000-\mathrm{m}^{3} / \mathrm{d}$ hypothetical new well field is added. Pathlines generally extend from each well field directly to the nearest general head boundary. The Livorno and Helena Christina well fields have the largest areas of capture in the model because they are farther from the main source of recharge outside the model boundary. Other well fields are nearer the boundary and have capture areas that extend there to draw in water high in dissolved chloride. Modpath was used to estimate time-of-travel along selected pathlines to a well field. The ground-water velocity averages about $133 \mathrm{~m} / \mathrm{yr}$ within $4 \mathrm{~km}$ of the Livorno well field. The program also was used to estimate time-of-travel along pathlines from the $300-\mathrm{mg} / \mathrm{L}$ chloride concentration line located north of Paramaribo toward pumping centers. Under 1987 pumping rates, ground water would move $6 \mathrm{~km}$ from the $300-\mathrm{mg} / \mathrm{L}$ chloride concentration line to the Livorno well field over a time period of about 40 years. Pathlines from the high-chloride area indicate that velocities are highest toward the Leysweg and Zorg en Hoop well fields, indicating a high potential for increasing chloride concentration in those supply wells. Conclusions drawn from this study are:

1. The A-Sand aquifer is overpumped. Water levels have declined steadily, as much as 15 to 20 meters since pumping began in 1958. Analytical and particle-tracking methods verify field observations, which demonstrate that water high in chloride has moved or will move into the northernmost well fields. Pumping from a hypothetical new well field in the northern half of the study area will eventually draw in high-chloride water. Pumping from a new well field in the southern half may cause excessive head declines in existing well fields.

2. The A-Sand aquifer is considered to be a leaky, confined system because the overlying and underlying units contain marine clays with a sand base and are unlikely to be impermeable. A model calibration was readily achieved using a leakance coefficient representative of marine clay and a constant aquifer hydraulic conductivity within the measured ranges.

3. The ability of the model to simulate two different hydrologic conditions accurately, 1987 steady-state conditions and 1958-87 transient conditions, lends credibility to the model as a tool for predicting the effects of ground-water development.

4. The Modpath program is a useful tool for illustrating pathlines of ground-water flow and time-of-travel within the ground-water system.

5. The A-Sand aquifer ground-water model could be improved through a program of hydrologic data collection. Hydraulic properties of the A-Sand aquifer and confining units need to be determined. The observation well network needs to be increased with wells in the Coesewijne and Onverdacht aquifers. Better definition of the chloride distribution needs to be made to evaluate the rate of lateral movement of water within the saltwater-freshwater transition zone to the pumping centers.

6. A feasibility study is needed to investigate methods for alleviating the critical water shortage at Paramaribo. The model can be used to assess the effects of increased pumping. Specifically, the model can be used to test future pumping scenarios, such as the addition of new wells to the supply network. Reduction in water use may be achieved by instituting programs of water conservation or mandatory restrictions. Alternative supply sources include importing water from distant aquifers or surface impoundments or desalinization. Saltwater intrusion may be attenuated by installing barrier wells north of the Leysweg and Zorg en Hoop well fields. 


\section{REFERENCES CITED}

Driscoll, F.G., 1986, Ground water and wells: St. Paul, Minn., Johnson Division, 1,108 p.

Freeze, R.A., and Cherry, J.A., 1979, Ground water: New Jersey, Prentice Hall, 604 p.

International Water Supply Consultants, B.V., 1981, Drinking-watervoorziening Commewijne: Consultant's report in files of the Suriname Water Company, $33 \mathrm{p}$.

McDonald, M.G., and Harbaugh, A.W., 1988, A modular three-dimensional finite-difference ground-water flow model: U.S. Geological Survey Techniques of Water-Resources Investigations, Book 6, Chap. A1, 576 p.

Mente, Albert, 1984, Planning ground-water monitoring in relation to the water supply system of Paramaribo, Suriname: Consultant's report to the Organization of American States, Department of Regional Development, $61 \mathrm{p}$.
Planning Research Corporation Engineering, Inc., 1988, Feasibility study and preliminary designs for the improvement and expansion of the potable water supply system for Paramaribo and its metropolitan area, Volume V, Annexes: Consultant's report to Inter-American Development Bank.

Pollock, D.W., 1989, Documentation of computer programs to compute and display pathlines using results from the U.S. Geological Survey modular three-dimensional finite-difference ground-water flow model: U.S. Geological Survey Open-File Report 89-381, 188 p.

United Nations Development Programme, 1972, Public water supplies and storage, volume 3 , water resources, hydrogeological and hydrological studies: World Health Organization, United Nations, Government of Suriname. 


\section{APPENDIX A}

\section{Model-Input Files}

This appendix is intended to serve as an operating manual for users of the Modular model of ground-water flow in the A-Sand aquifer. The appendix does not contain information concerning the Modpath particle-tracking program. The primary users of the model will be personnel at the Suriname Water Company and the Water Supply Service.

The computer programs and data files for the A-Sand aquifer model reside on two high-capacity 5.25-inch diskettes at the Suriname Water Company. The model is configured to run on an IBM ${ }^{1}$ AT personal computer with 640 kilobytes of memory, a highcapacity disk drive, and math coprocessor. A graphics output device, including dot matrix printer, pen plotter, and graphics screen, are desirable for reproducing and processing reported model runs and other predictive runs. The U.S. Geological Survey's Modular model (McDonald and Harbaugh, 1988) and accompanying software were purchased commercially by the Organization of American States. The package developed by Tecsoft, Inc., includes preprocessor and postprocessor programs that facilitate input and output. The hierarchy of programs and data files used in this study and contained on the two diskettes is listed in table 3. The ASAND root directory contains subdirectories CALIB, TRANS, and PREDICT where data files for the steady-state calibration, transient calibration, and predictive simulation reside, respectively.

Several "hands-on" sessions were held at the Suriname Water Company where trainees employed by the Water Supply Service and the Suriname Water Company were given a diskette containing the executable model program, a series of modularized data packages that represent the A-Sand aquifer, and a graphics package for plotting results. They proceeded with step-by-step written instructions to modify the model and reproduce the example simulation where a $6,000-\mathrm{m}^{3} / \mathrm{d}$ hypothetical new well field is installed.
Oral instructions were given for simulating the next example where 1987 pumping is redistributed and potential rates of saltwater encroachment are calculated. The participants then developed problems of current interest and applied the model to simulate the response of the system to new stresses.

Prediction of the long-term effect of a stress on the A-Sand aquifer is accomplished by using the steady-state model and programs in the PREDICT subdirectory. An example problem is intended to illustrate model input. The problem selected is one described in the main text and used in the training sessions where a $6,000-\mathrm{m}^{3} / \mathrm{d}$ hypothetical new well field is evaluated at row 22 and column 10. Input files listed below were set up according to guidelines in McDonald and Harbaugh (1988). The files can serve as a guide to reconstruction of the model.

Contour intervals of graphics plots are scaled automatically within the MODGRAF program. To control the interval, the program must be "tricked" into seeing a maximum and minimum range of values to contour. Oftentimes the range will be different for the potentiometric-surface and drawdown contour maps. The key to "tricking" the program is to set a value for grid blocks in the inactive area at the southeast corner of the model. A value of eight provided the contour intervals for the example problem. However, for other simulations, trial-and-error adjustment will be required to provide intelligible contour intervals.

To change the contour interval, the NEWELL.XYZ file must be edited. Change the potentiometric-surface interval in lines 362 to 736 by entering:

$$
\begin{aligned}
& 362,736 \mathrm{R} 8.000000^{\wedge} \mathrm{Z} 5.000000 \\
& (\text { remember } \wedge \text { Z is F6 key) }
\end{aligned}
$$

Change the drawdown interval in lines 1098 to 1472 by entering:

$1098,2000 \mathrm{R} 8.000000^{\wedge} \mathrm{Z} 1.000000$

Save the file, then return to MODGRAF and TRANSLATE.

\footnotetext{
${ }^{1}$ The use of brand or firm names in this report is for identification purposes only and does not constitute endorsement by the U.S. Geological Survey.
} 


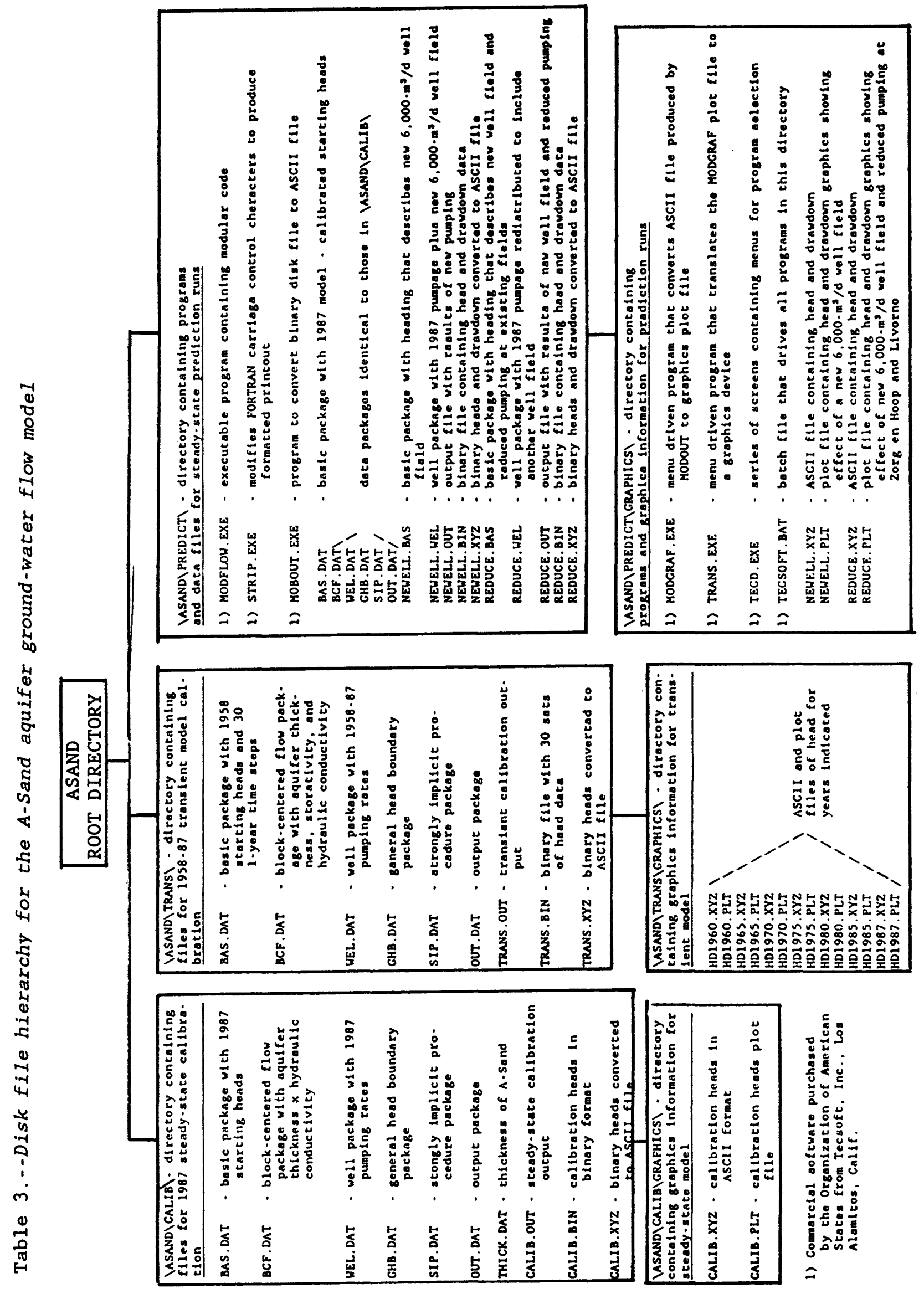


STEADY-STATE MODEL OF A-SAND AQUIFER AT PARAMARIBO, SURINAME PUMP 6,000 M**3/D FROM NEW WELL FIELD ROW22 COL10

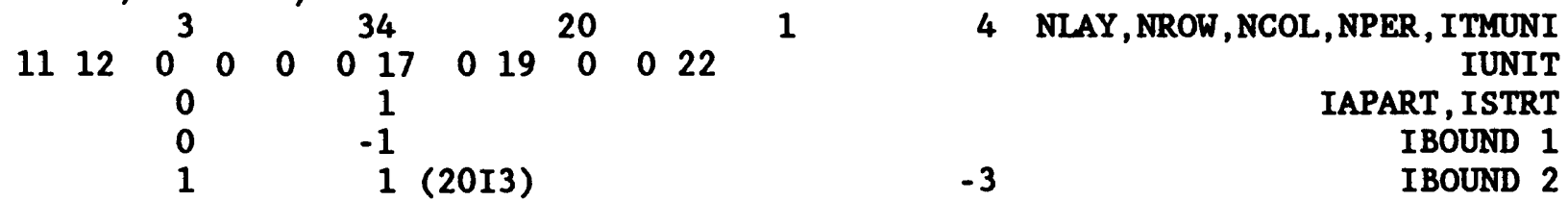

$\begin{array}{llllllllllllllllllll}1 & 1 & 1 & 1 & 1 & 1 & 1 & 1 & 0 & 0 & 0 & 0 & 0 & 0 & 0 & 0 & 0 & 0 & 0 & 0\end{array}$

$\begin{array}{llllllllllllllllllll}1 & 1 & 1 & 1 & 1 & 1 & 1 & 1 & 1 & 0 & 0 & 0 & 0 & 0 & 0 & 0 & 0 & 0 & 0 & 0\end{array}$

$\begin{array}{llllllllllllllllllll}1 & 1 & 1 & 1 & 1 & 1 & 1 & 1 & 1 & 1 & 1 & 0 & 0 & 0 & 0 & 0 & 0 & 0 & 0 & 0\end{array}$

$\begin{array}{llllllllllllllllllll}1 & 1 & 1 & 1 & 1 & 1 & 1 & 1 & 1 & 1 & 1 & 1 & 0 & 0 & 0 & 0 & 0 & 0 & 0 & 0\end{array}$

$\begin{array}{llllllllllllllllllll}1 & 1 & 1 & 1 & 1 & 1 & 1 & 1 & 1 & 1 & 1 & 1 & 1 & 1 & 0 & 0 & 0 & 0 & 0 & 0\end{array}$

$\begin{array}{llllllllllllllllllll}1 & 1 & 1 & 1 & 1 & 1 & 1 & 1 & 1 & 1 & 1 & 1 & 1 & 1 & 1 & 0 & 0 & 0 & 0 & 0\end{array}$

$\begin{array}{llllllllllllllllllll}1 & 1 & 1 & 1 & 1 & 1 & 1 & 1 & 1 & 1 & 1 & 1 & 1 & 1 & 1 & 1 & 1 & 0 & 0 & 0\end{array}$

$\begin{array}{llllllllllllllllllll}1 & 1 & 1 & 1 & 1 & 1 & 1 & 1 & 1 & 1 & 1 & 1 & 1 & 1 & 1 & 1 & 1 & 1 & 0 & 0\end{array}$

$\begin{array}{llllllllllllllllllll}1 & 1 & 1 & 1 & 1 & 1 & 1 & 1 & 1 & 1 & 1 & 1 & 1 & 1 & 1 & 1 & 1 & 1 & 0 & 0\end{array}$

$\begin{array}{llllllllllllllllllll}1 & 1 & 1 & 1 & 1 & 1 & 1 & 1 & 1 & 1 & 1 & 1 & 1 & 1 & 1 & 1 & 1 & 1 & 1 & 0\end{array}$

$\begin{array}{llllllllllllllllllll}1 & 1 & 1 & 1 & 1 & 1 & 1 & 1 & 1 & 1 & 1 & 1 & 1 & 1 & 1 & 1 & 1 & 1 & 1 & 0\end{array}$

$\begin{array}{llllllllllllllllllll}1 & 1 & 1 & 1 & 1 & 1 & 1 & 1 & 1 & 1 & 1 & 1 & 1 & 1 & 1 & 1 & 1 & 1 & 1 & 0\end{array}$

$\begin{array}{llllllllllllllllllll}1 & 1 & 1 & 1 & 1 & 1 & 1 & 1 & 1 & 1 & 1 & 1 & 1 & 1 & 1 & 1 & 1 & 1 & 1 & 1\end{array}$

$\begin{array}{llllllllllllllllllll}1 & 1 & 1 & 1 & 1 & 1 & 1 & 1 & 1 & 1 & 1 & 1 & 1 & 1 & 1 & 1 & 1 & 1 & 1 & 1\end{array}$

$\begin{array}{llllllllllllllllllll}1 & 1 & 1 & 1 & 1 & 1 & 1 & 1 & 1 & 1 & 1 & 1 & 1 & 1 & 1 & 1 & 1 & 1 & 1 & 1\end{array}$

$\begin{array}{llllllllllllllllllll}1 & 1 & 1 & 1 & 1 & 1 & 1 & 1 & 1 & 1 & 1 & 1 & 1 & 1 & 1 & 1 & 1 & 1 & 1 & 1\end{array}$

$\begin{array}{llllllllllllllllllll}1 & 1 & 1 & 1 & 1 & 1 & 1 & 1 & 1 & 1 & 1 & 1 & 1 & 1 & 1 & 1 & 1 & 1 & 1 & 1\end{array}$

$\begin{array}{llllllllllllllllllll}1 & 1 & 1 & 1 & 1 & 1 & 1 & 1 & 1 & 1 & 1 & 1 & 1 & 1 & 1 & 1 & 1 & 1 & 1 & 1\end{array}$

$\begin{array}{llllllllllllllllllll}1 & 1 & 1 & 1 & 1 & 1 & 1 & 1 & 1 & 1 & 1 & 1 & 1 & 1 & 1 & 1 & 1 & 1 & 1 & 1\end{array}$

$\begin{array}{llllllllllllllllllll}1 & 1 & 1 & 1 & 1 & 1 & 1 & 1 & 1 & 1 & 1 & 1 & 1 & 1 & 1 & 1 & 1 & 1 & 1 & 1\end{array}$

$\begin{array}{llllllllllllllllllll}1 & 1 & 1 & 1 & 1 & 1 & 1 & 1 & 1 & 1 & 1 & 1 & 1 & 1 & 1 & 1 & 1 & 1 & 1 & 1\end{array}$

$\begin{array}{llllllllllllllllllll}1 & 1 & 1 & 1 & 1 & 1 & 1 & 1 & 1 & 1 & 1 & 1 & 1 & 1 & 1 & 1 & 1 & 1 & 1 & 1\end{array}$

$\begin{array}{llllllllllllllllllll}1 & 1 & 1 & 1 & 1 & 1 & 1 & 1 & 1 & 1 & 1 & 1 & 1 & 1 & 1 & 1 & 1 & 1 & 1 & 1\end{array}$

$\begin{array}{llllllllllllllllllll}1 & 1 & 1 & 1 & 1 & 1 & 1 & 1 & 1 & 1 & 1 & 1 & 1 & 1 & 1 & 1 & 1 & 1 & 1 & 1\end{array}$

$\begin{array}{llllllllllllllllllll}1 & 1 & 1 & 1 & 1 & 1 & 1 & 1 & 1 & 1 & 1 & 1 & 1 & 1 & 1 & 1 & 1 & 1 & 1 & 1\end{array}$

$\begin{array}{llllllllllllllllllll}1 & 1 & 1 & 1 & 1 & 1 & 1 & 1 & 1 & 1 & 1 & 1 & 1 & 1 & 1 & 1 & 1 & 1 & 1 & 1\end{array}$

$\begin{array}{llllllllllllllllllll}1 & 1 & 1 & 1 & 1 & 1 & 1 & 1 & 1 & 1 & 1 & 1 & 1 & 1 & 1 & 1 & 1 & 1 & 1 & 1\end{array}$

$\begin{array}{llllllllllllllllllll}1 & 1 & 1 & 1 & 1 & 1 & 1 & 1 & 1 & 1 & 1 & 1 & 1 & 1 & 1 & 1 & 1 & 1 & 1 & 1\end{array}$

$\begin{array}{llllllllllllllllllll}1 & 1 & 1 & 1 & 1 & 1 & 1 & 1 & 1 & 1 & 1 & 1 & 1 & 1 & 1 & 1 & 1 & 1 & 1 & 1\end{array}$

$\begin{array}{llllllllllllllllllll}1 & 1 & 1 & 1 & 1 & 1 & 1 & 1 & 1 & 1 & 1 & 1 & 1 & 1 & 1 & 1 & 1 & 1 & 1 & 1\end{array}$

$\begin{array}{llllllllllllllllllll}1 & 1 & 1 & 1 & 1 & 1 & 1 & 1 & 1 & 1 & 1 & 1 & 1 & 1 & 1 & 1 & 1 & 1 & 1 & 1\end{array}$

$\begin{array}{llllllllllllllllllll}1 & 1 & 1 & 1 & 1 & 1 & 1 & 1 & 1 & 1 & 1 & 1 & 1 & 1 & 1 & 1 & 1 & 1 & 1 & 1\end{array}$

$\begin{array}{llllllllllllllllllll}1 & 1 & 1 & 1 & 1 & 1 & 1 & 1 & 1 & 1 & 1 & 1 & 1 & 1 & 1 & 1 & 1 & 1 & 1 & 1\end{array}$

$\begin{array}{llllllllllllllllllll}1 & 1 & 1 & 1 & 1 & 1 & 1 & 1 & 1 & 1 & 1 & 1 & 1 & 1 & 1 & 1 & 1 & 1 & 1 & 1\end{array}$

HNOFLO **NOTE THIS CONTROLS SCALE ON GRAPHICS PLOT 
1

$-1.862-2.139-2.487-2.826-3.116-3$

$\begin{array}{lllllll}0.000 & 0.000 & 0.000 & 0.000 & 0.000 & 0.000\end{array}$

$\begin{array}{llllll}-1.815 & -2.291 & -2.721 & -3.103 & -3.420 & -3.666\end{array}$

$\begin{array}{llllll}0.000 & 0.000 & 0.000 & 0.000 & 0.000 & 0.000\end{array}$

$\begin{array}{llllll}-1.902 & -2.441 & -2.926 & -3.331 & -3.659 & -3.927\end{array}$

$-5.544$

0.000

0.000

0.000

0.000

0.000

$-1.883-2.541$

$-5.971-6.371$

$-3.045$

$-3.455$

$-3.811$

$-4.117$

$-2.118-2.662$

0.000

0.000

0.000

0.000

$-6.432$

$-6.850$

$-3.131$

$-3.553$

.

$-4.313$

$-2.315-2.770$

3.215

0.000

0.000

$-4.526$

0.000

$\begin{array}{llll}-2.449 & -2.858 & -3.292 & -3.754\end{array}$

$-7.898$

$-4.247$

$-4.776$

$-8.162$

$-7.511$

7.810

$-8.008$

$-8.118$

2.536

$-2.921$

$-3.363$

$-3.866$

$-2.575$

$-8.976$

$-2.58$

$-9.655$

$-2.578$

$-10.51-11.27-10.56$

$\begin{array}{lll}-2.579 & -2.958 & -3.448\end{array}$

$-11.43-14.40-11.44$

$\begin{array}{llll}-2.587 & -2.949 & -3.393\end{array}$

$-10.60-11.44$

$-2.598-2.936$

$-10.52$

$-4.442$

$-8.164$

$-5.078$

$-8.425$

$-8.315$

$-8.485$

$-4.667-5.438$

$-8.696$

$-4.906$

$-8.495$

$-5.849$

$-8.954$

$-8.621$

$-6.245$

$-8.682$

$-9.764$

$-9.147-$

$-4.139$

$-5.107$

$-6.481$

$-9.189-8.626$

$-4.879-6.083$

$-8.936-8.405$

$-4.558-5.513$

$-8.478-8.040$

$-4.241-4.996$

$-2.604-2.919$

$1-9.476$

$-3.845$

$\begin{array}{lllll}-8.352 & -8.566 & -8.475 & -8.209\end{array}$

$-7.893$

$-7.558$

$-4.533$

$-2.611-2.907$

$-3.209$

$-3.542-3.956$

$-7.256-7.456$

$-7.226$

$-7.020$

$-2.641-2.906$

$-3.723-4.095$

$-6.599-6.533$

$-3.547-3.783$

$\begin{array}{lllllll}-5.222 & -5.515 & -5.718 & -5.843 & -5.971 & -6.049 \\ -2.763 & -2.922 & -3.090 & -3.256 & -3.416 & -3.572\end{array}$

$\begin{array}{lllllll}-2.763 & -2.922 & -3.090 & -3.256 & -3.416 & -3.572 \\ -4.487 & -4.763 & -5.020 & -5.214 & -5.401 & -5.708\end{array}$

$\begin{array}{lllllll}-4.487 & -4.763 & -5.020 & -5.214 & -5.401 & -5.708 \\ -2.780 & -2.914 & -3.050 & -3.184 & -3.310 & -3.424\end{array}$

$\begin{array}{lllllll}-2.780 & -2.914 & -3.050 & -3.184 & -3.310 & -3.424 \\ -3.975 & -4.191 & -4.459 & -4.721 & -5.007 & -5.527\end{array}$

$\begin{array}{llllll}-2.816 & -2.905 & -3.010 & -3.117 & -3.218 & -3.308\end{array}$

$\begin{array}{lllllll}-3.644 & -3.803 & -4.021 & -4.274 & -4.553 & -4.878\end{array}$

$\begin{array}{llllll}-2.811 & -2.880 & -2.964 & -3.052 & -3.136 & -3.210\end{array}$

$\begin{array}{llllll}-3.453 & -3.569 & -3.737 & -3.928 & -4.135 & -4.344\end{array}$

$\begin{array}{llllll}-2.781 & -2.843 & -2.914 & -2.988 & -3.060 & -3.125\end{array}$

$\begin{array}{llllll}-3.344 & -3.433 & -3.575 & -3.701 & -3.824 & -3.947\end{array}$

$-2.740-2.797$
8

$-3.464-3.511$

0.000

0.000

$0.000 \quad 0.000$

0.000

0.000

$\begin{array}{llll}3.862 & -4.060 & -4.408\end{array}$

0.000

$\begin{array}{lll}0.000 & 0.000 & 0.000\end{array}$

0.000

$-4.172-4.446$

$-4.799$

$-5.220$

0.000

0.000

0.000

0.000

$\begin{array}{lllll}0.409 & -4.724 & -5.101 & -5.553\end{array}$

$\begin{array}{lllll}0.000 & 0.000 & 0.000 & 0.000\end{array}$

$\begin{array}{lllll}-4.670 & -5.043 & -5.491 & -5.975\end{array}$

$\begin{array}{lllll}0.000 & 0.000 & 0.000 & 0.000\end{array}$

$\begin{array}{llll}-4.969 & -5.425 & -5.921 & -6.455\end{array}$

$\begin{array}{lllll}0.000 & 0.000 & 0.000 & 0.000\end{array}$

$\begin{array}{lllll} & 0.000 & 0.000 & 0.006 & 0.000\end{array}$

$\begin{array}{llll}-8.094 & 0.000 & 0.000 & 0.000\end{array}$

$\begin{array}{llll}-5.751 & -6.430 & -7.126 & -7.825\end{array}$

$\begin{array}{lllll}-8.170 & -8.056 & 0.000 & 0.000\end{array}$

$\begin{array}{lllll}-6.278 & -7.116 & -7.918 & -8.919\end{array}$

$\begin{array}{lllll}-8.278 & -8.097 & 0.000 & 0.000\end{array}$

$\begin{array}{llll}-6.914 & -7.965 & -8.640 & -9.251\end{array}$

$\begin{array}{lllll}-8.341 & -8.097 & -7.901 & 0.000\end{array}$

$\begin{array}{llll}-7.744 & -9.426 & -9.616 & -9.928\end{array}$

$\begin{array}{llll}-8.328 & -8.048 & -7.826 & 0.000\end{array}$

$\begin{array}{llll}-8.650 & -12.87 & -10.70 & -10.50\end{array}$

$\begin{array}{lllll}-8.220 & -7.901 & -7.630 & 0.000\end{array}$

$\begin{array}{lllll}-7.709 & -9.630 & -9.775 & -9.984\end{array}$

$\begin{array}{lllll}-7.995 & -7.640 & -7.324 & -9.038\end{array}$

$\begin{array}{lllll}-6.670 & -7.928 & -8.574 & -9.020\end{array}$

$\begin{array}{lllll}-7.665 & -7.325 & -7.047 & -6.835\end{array}$

$\begin{array}{lllll}-5.925 & -7.008 & -7.561 & -7.988\end{array}$

$\begin{array}{lllll}-7.246 & -6.957 & -6.727 & -6.536\end{array}$

$\begin{array}{lllll}-5.372 & -6.896 & -6.774 & -6.981\end{array}$

$\begin{array}{llll}-6.820 & -6.590 & -6.339 & -6.160\end{array}$

$\begin{array}{lllll}-4.605 & -5.265 & -5.591 & -5.878\end{array}$

$\begin{array}{lllll}-6.376 & -6.143 & -5.882 & -5.751\end{array}$

$\begin{array}{lllll}-4.055 & -4.377 & -4.654 & -4.933\end{array}$

$\begin{array}{lllll}-5.996 & -5.748 & -5.533 & -5.438\end{array}$

$\begin{array}{lllll}-3.725 & -3.880 & -4.047 & -4.253\end{array}$

$\begin{array}{lllll}-5.967 & -5.588 & -5.331 & -5.206\end{array}$

$\begin{array}{lllll}-3.521 & -3.602 & -3.679 & -3.796\end{array}$

$\begin{array}{lllll}-6.525 & -5.488 & -5.121 & -4.971\end{array}$

$\begin{array}{lllll}-3.382 & -3.436 & -3.479 & -3.536\end{array}$

$\begin{array}{lllll}-5.172 & -4.955 & -4.789 & -4.695\end{array}$

$\begin{array}{llll}-3.273 & -3.321 & -3.356 & -3.392\end{array}$

$\begin{array}{lllll}-4.489 & -4.478 & -4.423 & -4.385\end{array}$

$\begin{array}{llll}-3.182 & -3.228 & -3.265 & -3.296\end{array}$

$\begin{array}{lllll}-4.045 & -4.081 & -4.080 & -4.072\end{array}$

$\begin{array}{llll}-3.101 & -3.147 & -3.188 & -3.226\end{array}$
HEAD 2 


$\begin{array}{lllllllllll}-3.275 & -3.366 & -3.534 & -3.561 & -3.598 & -3.658 & -3.720 & -3.759 & -3.778 & -3.784 \\ -2.690 & -2.746 & -2.803 & -2.863 & -2.921 & -2.976 & -3.027 & -3.074 & -3.117 & -3.162 \\ -3.220 & -3.333 & -3.680 & -3.471 & -3.418 & -3.432 & -3.466 & -3.498 & -3.519 & -3.530 \\ -2.639 & -2.689 & -2.743 & -2.798 & -2.853 & -2.906 & -2.955 & -3.001 & -3.045 & -3.089 \\ -3.137 & -3.198 & -3.277 & -3.244 & -3.226 & -3.233 & -3.255 & -3.282 & -3.301 & -3.310 \\ -2.573 & -2.625 & -2.679 & -2.733 & -2.786 & -2.836 & -2.884 & -2.928 & -2.970 & -3.009 \\ -3.046 & -3.079 & -3.100 & -3.084 & -3.073 & -3.074 & -3.086 & -3.103 & -3.118 & -3.125 \\ -2.493 & -2.549 & -2.608 & -2.665 & -2.718 & -2.768 & -2.814 & -2.857 & -2.896 & -2.930 \\ -2.958 & -2.978 & -2.984 & -2.973 & -2.959 & -2.955 & -2.956 & -2.961 & -2.968 & -2.970 \\ -2.400 & -2.464 & -2.527 & -2.589 & -2.645 & -2.697 & -2.745 & -2.786 & -2.823 & -2.853 \\ -2.876 & -2.891 & -2.893 & -2.885 & -2.869 & -2.859 & -2.853 & -2.849 & -2.847 & -2.846 \\ -2.293 & -2.368 & -2.439 & -2.506 & -2.567 & -2.622 & -2.672 & -2.715 & -2.751 & -2.780 \\ -2.801 & -2.814 & -2.816 & -2.810 & -2.796 & -2.780 & -2.769 & -2.759 & -2.751 & -2.749 \\ -2.164 & -2.254 & -2.338 & -2.414 & -2.482 & -2.542 & -2.596 & -2.642 & -2.680 & -2.710 \\ -2.731 & -2.743 & -2.747 & -2.742 & -2.732 & -2.716 & -2.701 & -2.687 & -2.676 & -2.671 \\ -2.024 & -2.126 & -2.220 & -2.307 & -2.387 & -2.456 & -2.516 & -2.567 & -2.609 & -2.641 \\ -2.665 & -2.679 & -2.685 & -2.684 & -2.676 & -2.663 & -2.646 & -2.631 & -2.618 & -2.607 \\ -1.878 & -1.989 & -2.088 & -2.182 & -2.272 & -2.352 & -2.422 & -2.484 & -2.535 & -2.574 \\ -2.602 & -2.621 & -2.631 & -2.633 & -2.628 & -2.618 & -2.603 & -2.586 & -2.570 & -2.558 \\ -1.779 & -1.849 & -1.941 & -2.041 & -2.141 & -2.240 & -2.320 & -2.393 & -2.456 & -2.506 \\ -2.542 & -2.568 & -2.583 & -2.589 & -2.588 & -2.580 & -2.566 & -2.549 & -2.530 & -2.516 \\ 0 & 4 & & & & & & & \\ 3 & 0 & 1 & & 1 & & & & & & \end{array}$




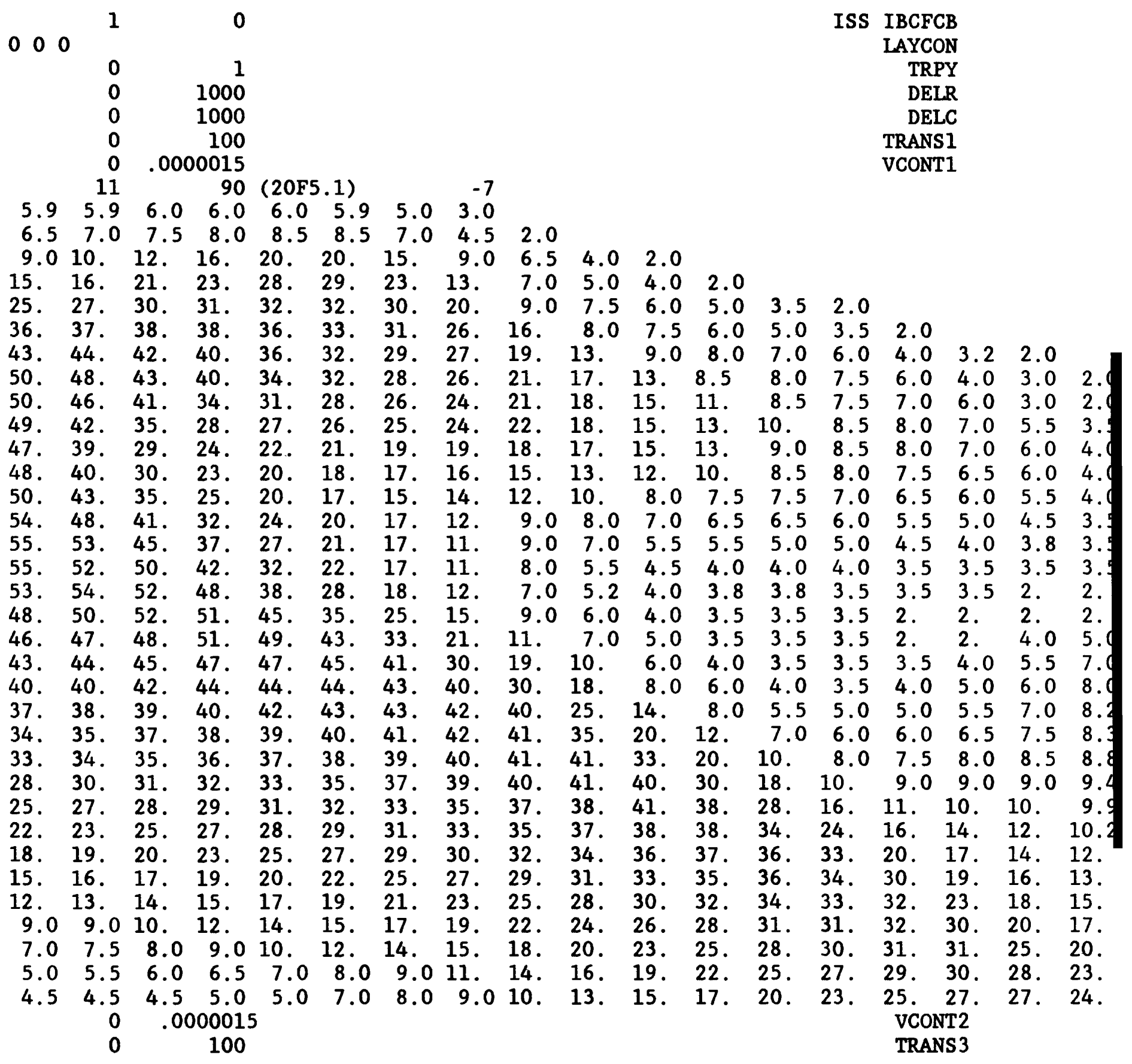


WEL, DAT - We11 package

$\begin{array}{rrrrl}7 & 0 & & & \\ 7 & & & & \\ 2 & 9 & 10 & -2880 & \text { Meerzorg } \\ 2 & 12 & 8 & -19059 & \text { Zoorg en Hoop 1987 } \\ 2 & 12 & 12 & -10877 & \text { Livorno 1987 } \\ 2 & 16 & 8 & -3538 & \text { Leysweg 1987 } \\ 2 & 20 & 17 & -1950 & \text { Helena Christiana } \\ 2 & 25 & 13 & -1926 & \text { Koewarasan } \\ 2 & 22 & 10 & -6000 & \text { NEW WELL FIELD }\end{array}$

MXWELL, IWELBD

WELL

GHB .DAT--General-head boundary package

\begin{tabular}{|c|c|c|c|c|}
\hline $\begin{array}{l}60 \\
60\end{array}$ & 0 & & & \\
\hline 2 & 1 & 1 & 3. & 22.00 \\
\hline 2 & 1 & 2 & 3. & 22.00 \\
\hline 2 & 1 & 3 & 3. & 22.00 \\
\hline 2 & 1 & 4 & 3. & 22.00 \\
\hline 2 & 1 & 5 & 3. & 22.00 \\
\hline 2 & 1 & 6 & 3. & 22.00 \\
\hline 2 & 1 & 7 & 3. & 22.00 \\
\hline 2 & 1 & 8 & 3. & 22.00 \\
\hline 2 & 2 & 1 & 3. & 75.00 \\
\hline 2 & 3 & 1 & 3. & 75.00 \\
\hline 2 & 4 & 1 & 3. & 270.00 \\
\hline 2 & 5 & 1 & 3. & 270.00 \\
\hline 2 & 6 & 1 & 3. & 270.00 \\
\hline 2 & 7 & 1 & 3. & 270.00 \\
\hline 2 & 8 & 1 & 3. & 270.00 \\
\hline 2 & 9 & 1 & 3. & 270.00 \\
\hline 2 & 10 & 1 & 3. & 270.00 \\
\hline 2 & 11 & 1 & 3. & 270.00 \\
\hline 2 & 12 & 1 & 3. & 270.00 \\
\hline 2 & 13 & 1 & 3. & 270.00 \\
\hline 2 & 14 & 1 & 3. & 270.00 \\
\hline 2 & 15 & 1 & 3. & 270.00 \\
\hline 2 & 16 & 1 & 3. & 270.00 \\
\hline 2 & 17 & 1 & 3. & 270.00 \\
\hline 2 & 18 & 1 & 3. & 100.00 \\
\hline 2 & 19 & 1 & 3. & 100.00 \\
\hline 2 & 20 & 1 & 3. & 100.00 \\
\hline 2 & 21 & 1 & 3. & 25.00 \\
\hline 2 & 22 & 1 & 3. & 25.00 \\
\hline 2 & 23 & 1 & 3. & 25.00 \\
\hline 2 & 24 & 1 & 3. & 25.00 \\
\hline
\end{tabular}




$\begin{array}{lllll}2 & 25 & 1 & 3 . & 25.00 \\ 2 & 26 & 1 & 3 . & 15.00 \\ 2 & 27 & 1 & 3 . & 15.00 \\ 2 & 28 & 1 & 3 . & 15.00 \\ 2 & 29 & 1 & 3 . & 15.00 \\ 2 & 30 & 1 & 3 . & 15.00 \\ 2 & 31 & 1 & 3 . & 15.00 \\ 2 & 32 & 1 & 3 . & 15.00 \\ 2 & 33 & 1 & 3 . & 15.00 \\ 2 & 34 & 1 & 3 . & 12.0 \\ 2 & 34 & 2 & 3 . & 12.0 \\ 2 & 34 & 3 & 3 . & 12.0 \\ 2 & 34 & 4 & 3 . & 12.0 \\ 2 & 34 & 5 & 3 . & 12.0 \\ 2 & 34 & 6 & 3 . & 12.0 \\ 2 & 34 & 7 & 3 . & 12.0 \\ 2 & 34 & 8 & 3 . & 12.0 \\ 2 & 34 & 9 & 3 . & 12.0 \\ 2 & 34 & 10 & 3 . & 12.0 \\ 2 & 34 & 11 & 3 . & 12.0 \\ 2 & 34 & 12 & 3 . & 12.0 \\ 2 & 34 & 13 & 3 . & 12.0 \\ 2 & 34 & 14 & 3 . & 12.0 \\ 2 & 34 & 15 & 3 . & 12.0 \\ 2 & 34 & 16 & 3 . & 12.0 \\ 2 & 34 & 17 & 3 . & 12.0 \\ 2 & 34 & 18 & 3 . & 12.0 \\ 2 & 34 & 19 & 3 . & 12.0 \\ 2 & 34 & 20 & 3 . & 12.0\end{array}$

SIP.DAT--Strongly implicit procedure package

50

1
1

1
MXITER, NPARM

$O$ ACCL, HCLOSE, IPCALC, WSEED, IPRSIP

OUT.DAT--Output control package

$\begin{array}{rrrr}8 & 8 & 25 & 25 \\ 1 & 1 & 1 & 0 \\ 0 & 0 & 0 & 0 \\ 1 & 1 & 1 & 1 \\ 0 & 0 & 0 & 0\end{array}$

IHEDFM, IDDNFM, IHEDUN, IDDNUN INCODE , IHDDFL, IBUDFL, ICBCFL HDPR, DDPR, HDSV, DDSV for layer 1 for layer 2 for layer 3 


\section{APPENDIX B}

Computer Procedures

Problem--Add $6000 \mathrm{~m} * 3 / \mathrm{d}$ hypothetical new wellfield to row 22 column 10

**Note--Keyboard commands are capitalized and underlined

Create directories on the hard disk (drive 'C')

\section{$\mathrm{C}: \backslash>$ MD $\backslash$ ASAND $\backslash$ PREDICT}

$C: \backslash>$ MD \ASAND \PREDICT \GRAPHICS

Insert diskette no. 2 with \asand \predict\directories into drive 'A'

Load files from diskette to equivalent directories on hard disk

$C: \backslash$ A :

$A: \backslash>$ CD \ASAND $\backslash$ PREDICT

A: $\backslash$ ASAND $\backslash$ PREDICT $>$ COPY * * C $: \backslash$ ASAND $\backslash$ PREDICT

MODFLOW. EXE

SIP.DAT

MODOUT . EXE

STRIP.EXE

NEWELL. OUT

NEWELL . WEL

NEWELL. BIN

NEWELL . XYZ

NEWELL. BAS

GHB. DAT

REDUCE. BIN

BCF. DAT

REDUCE. WEL

OUT. DAT

REDUCE. OUT

WEL. DAT

REDUCE. XYZ

REDUCE. BAS

BAS. DAT

19 File(s) copied

$A: \backslash A S A N D \backslash P R E D I C T>C D \backslash A S A N D \backslash P R E D I C T \backslash G R A P H I C S$ 
AI \ASAND \PREDICT IGRAPHICS >COPY * * CI IASAND \PREDICTIGRAFHICS

MODGRAF. EXE

TRANS. EXE

TECD. EXE

TECSOFT.BAT

NEWELL.PLT

NEWELL , XYZ

REDUCE, PLT

REDUCE , $X Y Z$

B File(æ) copied

Remove diskette and tranfer control to hard disk

A: \ASAND \PREDICT \GRAPHICS〉 E:

C: $>$ CD \ASAND $\triangle P R E D I C T$

Edit heading in data file BAS.DAT

C: \ASAND \PREDICT \EDLIN BAS. DAT

End of input file

*2

2.*CALIBRATIONI 1958-87 FUMPING CONDITIONS

2: *PUMP $6000 \mathrm{M**3/D}$ FROM NEW WELLFIELD ROW 22 COL 10

*E

Edit heading in well package WEL. DAT

C: \ABAND \FREDICT \EDL IN WEL. DAT

End of input file

*1

*2

$11 *$

$6 \quad 0$

MXWELL, IWELBD
MXWELL, IWELBD

$11 *$

0

MXWELL, IWELBD
MXWELL, IWELBD

$* 2$

\section{$21 *$}

21*

$* 1,10 \mathrm{~L}$

\section{1.}

2:*

3.

4!

51

61

7:

8 I

$$
7
$$

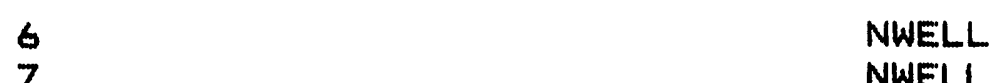

7 NWELL

* $\underline{9 I}$

$\begin{array}{rrrrl}7 & 0 & & & \text { MXWELL, IWELBD } \\ 7 & & & \text { NWELL } \\ 2 & 9 & 10 & -2880 & \text { Meerzorg } \\ 2 & 12 & 8 & -19059 & \text { Zoorg en Hoop } 1987 \\ 2 & 12 & 12 & -10877 & \text { Livorno } 1987 \\ 2 & 16 & 8 & -3538 & \text { Ley weg 1987 } \\ 2 & 20 & 17 & -1950 & \text { Helena Chri istiana } \\ 2 & 25 & 13 & -1926 & \text { Koewarasan }\end{array}$

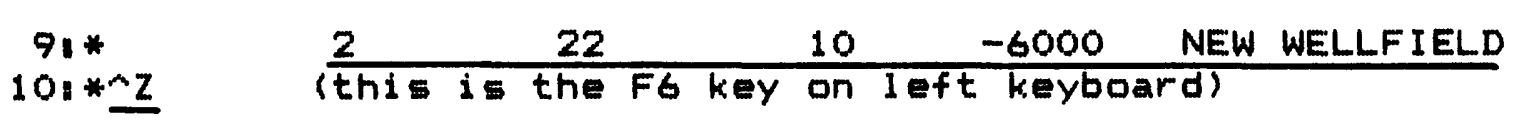

*E

Run the model 
ENTER HARDCOPY FILE NAME: NEWELL. OUT

ENTER BAS FILE NAME: BAS.DAT

Fress ENTER to continue, ESC TO quit..

ENTER BCF FILE NAME: BCF.DAT

ENTER WEL FILE NAME: WEL.DAT

ENTEF GHB FILE NAME, GHE.DAT

ENTEF SIF FILE NAME: SIP.DAT

ENTER OUTFUT FILE NAME, DUT.DAT

Press ENTEF to continue, ESC TO quit.. 


$$
\begin{aligned}
& \langle 1\rangle-\cdots \text { MODGRAF FORMAT } \\
& \langle 2\rangle-\cdots, x, z \text { FORMAT }
\end{aligned}
$$

ENTER SELECTION: 1

ENTER XYZ FILE NAME: NEWELL. XYZ

ENTER HARDCOPY OUTPUT FILE NAME:

NEWELL. HRD

Press RETURN to continue, ESC to quit.. 
EINARY HEAD DATA FILEI NEWELL.BIN

Computing, please wait...

If desired, print the output by entering FRINT NEWELL. OUT

Or prepare graphics images of head or drawdown using MODOUT

\ \ASAND \FREDICT >MODOUT

INPUT FILES

ENTER DRIVE LETTER FOR INFUT/OUTFUT FILES: c

ENTER BAS FILE NAME: BAS.DAT

ENTER ECF FILE NAME: ECF.DAT

ENTER EINARY OUTPUT FILE NAME: NEWELL.BIN 


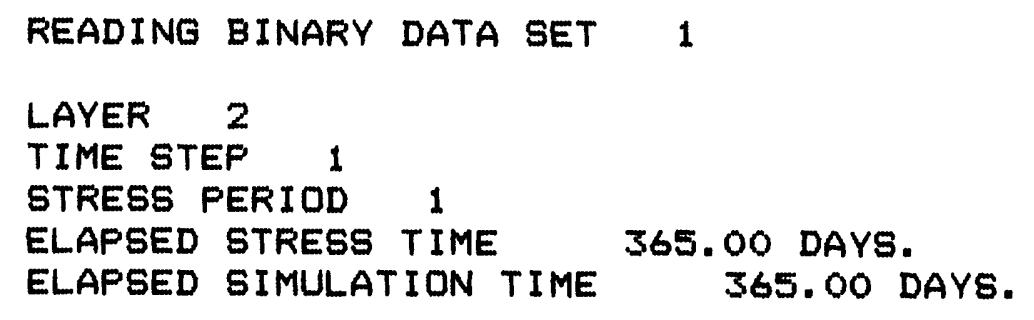

DO YOU WISH TO CONTOUR THIS DATA $(Y / N) ? \underline{Y}$

READ AND WRITE HEAD DATA

READING BINARY DATA SET 2

LAYER 2

TIME STEP 1

STRESS PERIOD 1

ELAPSED STRESS TIME 365.00 DAYS.

ELAPSED SIMULATION TIME $\quad 365.00$ DAYS.

DO YOU WISH TO CONTOUR THIS DATA (Y/N)?: $\underline{Y}$

Copy output of MODOUT program to graphics directory

C: \ASAND \PREDICT >COPY NEWELL. XYZ \ASAND $\backslash P R E D I C T \backslash G R A P H I C S$

1 File (s) copied

C: \ASAND \PREDICT $>$ Move into graphics subdirectory

C : \ASAND \PREDICT $>$ CD $\backslash$ ASAND $\backslash$ PREDICT \GRAPHICS

Frepare plot file using MODGRAF program

Enter 'TECSOFT', press down arrow to MODGRAF (19) and press 'ENTER' 
C: $\backslash$ ASAND $\backslash$ PREDICT \GRAPHICS $\backslash$ TECSOFT

$C: \backslash A S A N D \backslash P R E D I C T \backslash G R A P H I C S>$ echo of $f$

TE C S O F T P R O G R A M A C C E S S S Y S T E M.

Version 3.3

(C) Copyright $1985,86,87,88$.

TECSOFT INC.

Fri Nov $1106: 01: 54 \mathrm{pm}$

$640 \mathrm{~Kb}$ Memory

2273280 Bytes Free

DDDDDDDDDDDDDDDDDDDDDDDDDDDDDDDDDDDDDDDDDDDDDDDDDDDDDDDDDDDDDDDDDDDDDDDDDD:

10. AQUABASE V2.0 3-D Water Quality Data Storage \& Statistical Analysis.

11. TECWVEL V1.0 Groundwater Velocity (Average, Local).

12. TECVECT V1.0 2-D Vector Field Generator.

13. TECDRAW V1.0 Plot Drawdown and Recovery Data. For Use With TECTYPEx

14. TECTYPC V1.1 Type Curve Generation, Confined, Constant Rate.

15. TECTYPL V1.1 Type Curve Generation, Leaky, Constant Rate.

16. TECTYPU V1.1 Type Curve Generation, Unconfined, Constant Rate.

17. TECMOUND V1.1 Mounding Due To Artificial Recharge - Glover Solution

18. TECAUTO V1.0 Automatic Pump Test Analysis

19. MODGRAF V1.3 McDonald Modular Flow (MODFLOW) Graphics Module

DDDDDDDDDDDDDDDDDDDDDDDDD 20 Options Available DDDDDDDDDDDDDDDDDDDDDDDDDDD

Enter default data drive: $\underline{C}$ :

, Home, End, PgUp, PgDn keys and carriage return to select option.

F1 key toggles color off.

Escape exits to operating system.

Type $V$ to view a file. Type $P$ to print a file. Type $D$ for directory

ENTER DATA FILE NAME: NEWELL.XYZ

ENTER PLOT FILE NAME: NEWELL.PLT

CREATE A HARDCOPY OUTPUT FILE (Y/N)? N

Press ENTER to continue, ESC TO quit... 
BUILDING PLOT FOR DATA SET NUMBERI 1

Computing, Please Wait...

LABEL OPTIONS

DO YOU WANT A TITLE ON THE PLOT $(Y / N)$ ? Y

POTSURF WITH NEW $6000 \mathrm{M**3/D \text {WELLFIELD }}$

DO YOU WANT A LABEL ON THE X-AXIS (Y/N)? $Y$ COLUMNS

DO YOU WANT A LABEL ON THE Y-AXIS $(Y / N) ? \underline{Y}$ ROWS

Press ENTER to continue, ESC to quit... 
DO YOU WANT A TITLE ON THE PLOT ( $Y / N) ? \underline{Y}$ DDN WITH NEW $6000 \quad M * * 3 / D$ WELLFIELD

DO YOU WANT A LABEL ON THE X-AXIS $(Y / N) ? \underline{Y}$ COLUMNS

DO YOU WANT A LABEL ON THE Y-AXIS (Y/N)? Y ROWS

Press ENTER to continue, ESC to quit... 
Create graphics plot using the TRANSLATE program

$$
\begin{aligned}
& \text { TEC S DF T PRDGRAM ACCES S S Y STE M. } \\
& \text { Version } 3.3 \quad \text { (C) Copyright } 1985,86,87,88 .
\end{aligned}
$$

Fri Nov $1104159103 \mathrm{pm} \quad 640 \mathrm{~kb}$ Memary

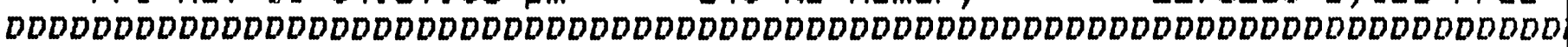

1. TRANSLATE V4.1 Metacode Graphics Translator.

2. PLOTCHEM V4.0 GeOChemical Diagrams \& Constituent Summaries.

3. TEDIT V3.0 2-D Spreadsheet Editor for TKON2I \& TECGRAF.

4. TECGRAF V1.2 General XY Flotting including Vertical Frofile Filots

5. TKON2I V1.7 2-D Contouring of Irregular (Scattered) Data.

6. TKON2R V1.0 2-D Contouring of Regular (Gridded) Data.

7. TKON3D V1.2 3-D Contouring of Regular (Gridded) Data.

8. TKONC V1.1 Cross-Sectional View of Contoured Surface(s).

9. TKONV V1.0 Volume Estimatation Between Two Contoured Surfaces.

10. AQUABASE V2.0 3-D Water Quality Data Storage \& Statistical Analysi

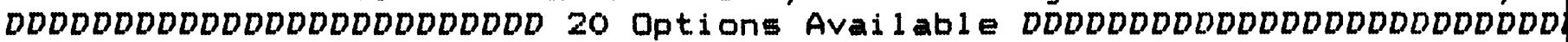

Enter default data driverC.

- Home, End, Pgup, PgDn keys and carriage return to select option. F1 key toggles calor off. Escape exits to operating syst Type $V$ to view a file. Type $P$ to print a file. Type $D$ for director

E.

Resident portion of MODE loaded

COM1: $9600, e, 7,1, p$

COM2, $9600, e, 7,1, p$

ENTER PLOT FILE NAME! newe11.p1t 
$\langle 1\rangle$ VECTOR PLOTTERS

$\langle 2\rangle$ SCREEN GRAPHICS

$\langle 3\rangle$ PRINTER GRAPHICS

〈R〉 RETURN TO PREVIOUE MENU

〈E〉 EXIT TO TECSOFT ACCESS MENU

\section{ENTER GRAPHICS SELECTION: 2}

c

COM1, $9600, E, 7,1, P$

$\operatorname{COM} 2,9600, e, 7,1, p$ 


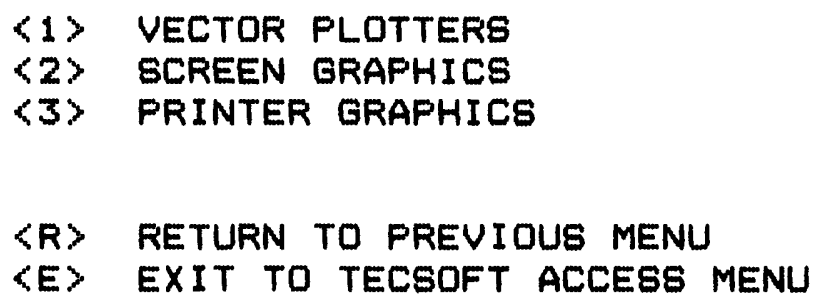

ENTER GRAPHICS SELECTION: 2

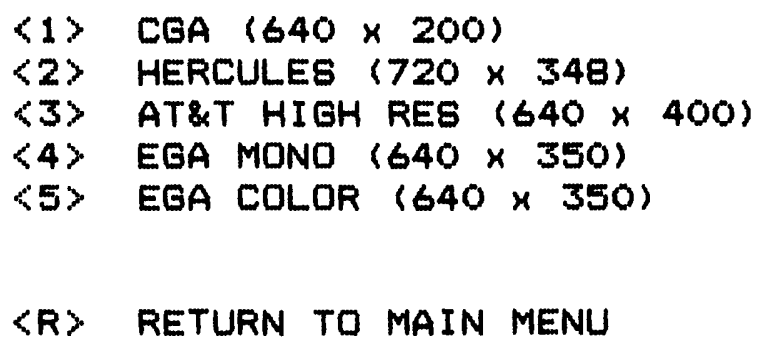

ENTER SELECTION: 1 
TRANELATOR OPTIONE

〈P〉 ---- PLOT THIS PICTURE
$\langle$ 〈S --- SKIP THIS PICTURE

〈R〉 --- RESELECT GRAPHICS DEVICE

ENTER SELECTION: $\underline{P}$

TRANSLATOR DPTIONS

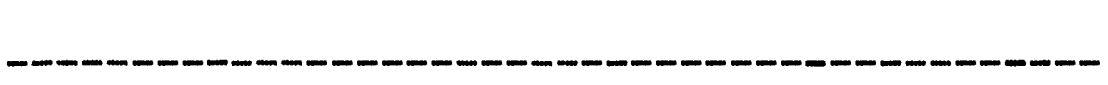

〈P〉 --- PLQT THIS PICTURE

〈S〉 --- SKIP THIS PICTURE

〈R〉 - - RESELECT GRAPHICS DEVICE

ENTER SELECTION: $\underline{R}$ 


\begin{abstract}
〈1〉 VECTOR PLOTTERS
〈2〉 SCREEN GRAPHICS

$\langle 3\rangle$ PRINTER GRAPHICS

〈R〉 RETURN TO PREVIOUS MENU

〈E〉 EXIT TO TECSOFT ACCESS MENU

ENTER GRAFHICS SELECTION: 3

ENTER PARALLEL PORT\# $(1,2,3): 1$
\end{abstract}

FRINTER GRAFHICS

\footnotetext{
(1) IBM, EPSON (FX,LX,RX,MX), COMREX - SINGLE DENSITY

(2) IBM, EPSON $(F X, L X, R X, M X)$, COMREX - DOUBLE DENSITY

〈3) EPSON LQ SERIES - SINGLE DENSITY

〈4〉 EPSON LQ SERIES - DOUBLE DENSITY

〈5> HF LASER JET SERIES I I

〈R〉 RETURN TO MAIN MENU
}

ENTER SELECTION: 1 or $\underline{2}$ 
TFA A S L A T OF OF T I DNS

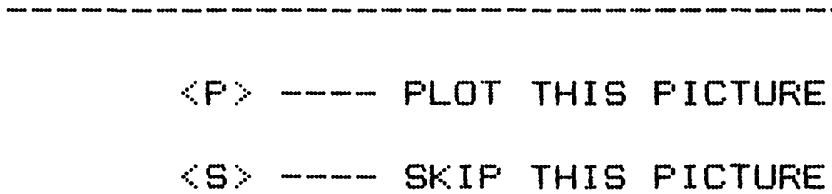

SR〉 - - FESELECT GFAFHICS DEVICE

ENTEF SELECTION: P

FLOTTING FRAME NUMEER

1 


\section{POTSURF WITH NEW $6000 \mathrm{M}^{* * 3 / D ~ W E L L F I E L D ~}$}

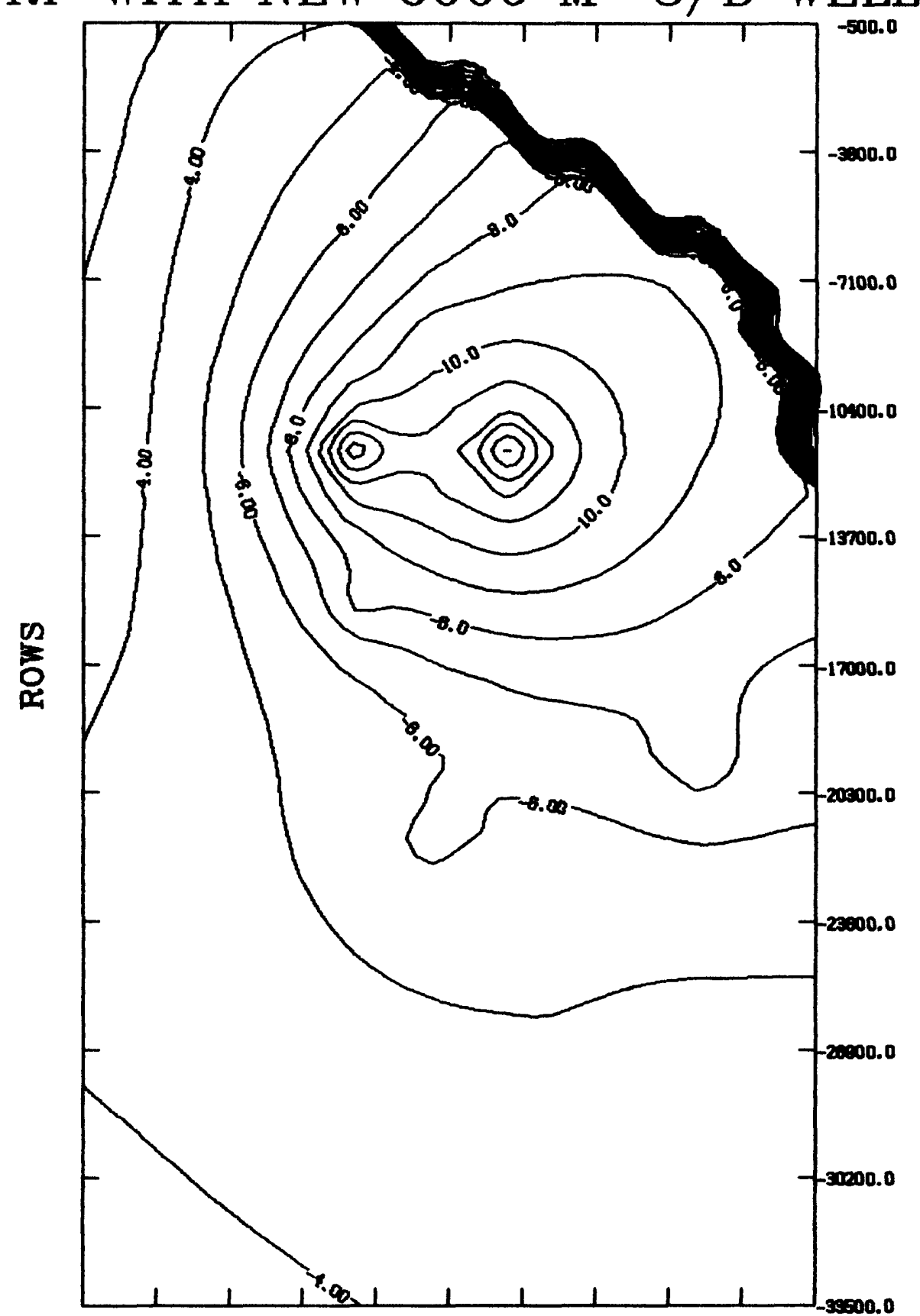

500.02400 .04300 .08200 .08100 .010000 .011000 .013000 .015700 .017600 .016500 .0 COLUMNS 
T R A N S L A T O R O P T I O N S

$$
\begin{aligned}
& \text { 〈P〉 - -- PLOT THIS PICTURE } \\
& \text { 〈S〉 - - SKIP THIS PICTURE }
\end{aligned}
$$

$$
\text { 〈R> - - RESELECT GRAPHICS DEVICE }
$$




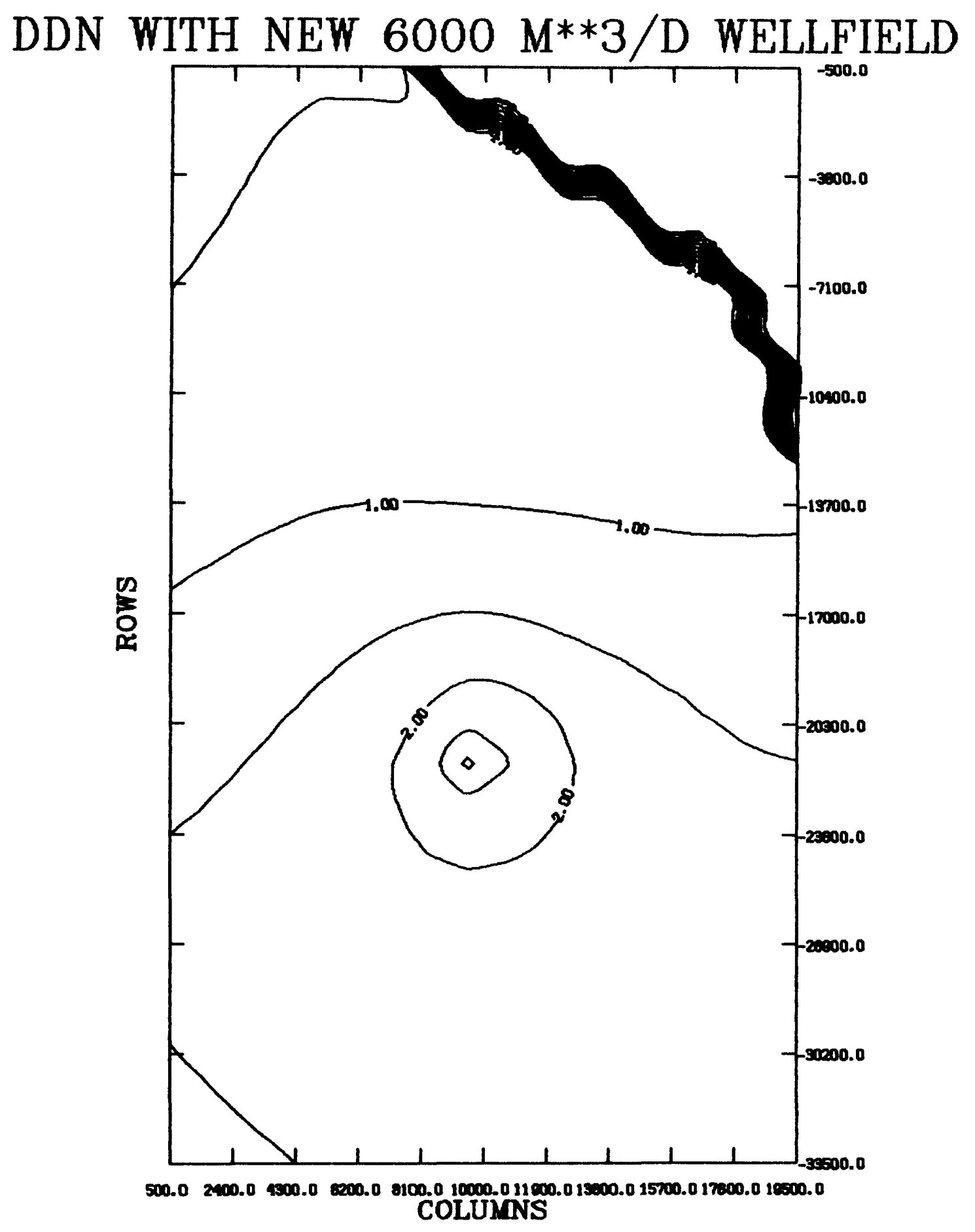


Contour intervals of graphics plots are scaled automatically within the MODGRAF program. To control the contour interval the program must be "tricked" into seeing a maximum and minimum range of values to contour. Oftentimes the range will be different for the potentiometric surface and drawdown contour maps. The key to "tricking" the program is to set the value for grid blocks in the inactive area at the southeast corner of the model. A value of 8 provided the contour intervals for the example problem. However, for other simulations trial-and-error adjustment will be required to provide intelligible contour intervals.

To change the contour interval the NEWELL.XYZ file must be edited. Change the potentiometric surface interval in lines 362 to 736 by entering:

$$
362,736 \mathrm{R} 8.000000^{\wedge} \mathrm{Z} 5.000000 \text { (remember ^ } \mathrm{Z} \text { is F6 key) }
$$

Change the drawdown interval in lines 1098 to 1472 by entering:

$$
1098,2000 \mathrm{R} 8.000000^{\wedge} \mathrm{Z} 1.000000
$$

Save the file, then return to MODGRAF and TRANSLATE. 


\section{APPENDIX C}

Model Output

U.S. GEOLOGICAL SURVEY MODULAR FINITE-DIFPERENCE GROUND-WATER MODEL

STEADY-STATE MODEL OF A-SAND AQUIFER AT PARAMARIBO, SURINAME PUMP $6000 M \star \star 3 / D$ FROM NEW WELLFIELD ROW22 COL 10 3 LAYERS 34 ROWS 20 COLURAS 1 STRESS PERIOD(S) IN

I/O UNITS:

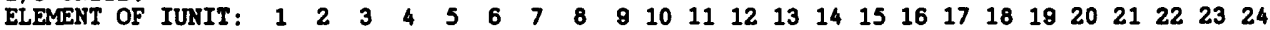

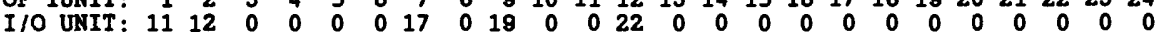

BAS1 -- BASIC MODEL PACKAGE, VERSION $1,12 / 08 / 83$ INPUT READ FROM UNIT 1

ARRAYS RHS AND BUFF WILL SHARE MEYORY.

START HEAD WILL BE SAVED

19786 ELEMENTS IN X ARRAY ARE USED BY BAS

19786 ELEMENTS OF X ARRAY USED OUT OF 100000

BCF 1 -- BLOCK-CENTERED FLOW PACKAGE, VERSION 1, 12/08/83 INPUT READ FRON UNIT 11

STEADY-STATE SIMULATION

LAYER AQUIFER TYPE

$\begin{array}{ll}1 & 0 \\ 2 & 0 \\ 3 & 0\end{array}$

3 ELEMENTS IN $X$ ARRAY ARE USED BY BCF

19789 ELEMENTS OF X ARRAY USED OUT OF 100000

WEL 1 - - WELL PACKAGE VERSION 1, 12/08/83 INPUT READ FROM 12

WEL1 -- WELL PACKAGE,

28 ELEMENTS IN X ARRAY ARE USED FOR WELLS

19817 ELEMENTS OF X ARRAY USED OUT OF 100000

GHB1 -- GHB PACKAGE, VERSION 1, 12/08/83 INPUT READ FROM UNIT 17

MAXIMUM OF 60 HEAD-DEPENDENT' BOUNDARY NODES

300 ELEMENTS IN $X$ ARRAY ARE USED FOR HEAD-DEPENDENT BOUNDARTES

20117 ELEMENTS OF X ARRAY USED OUT OF 100000

SIP1 -- STRONGLY IMPLICIT PROCEDURE SOLUTION PACKAGE, VERSION 1, 12/08/83 INPUT READ FROM UNIT 19 MAXIMUM OF 50 ITERATIONS ALLOWED FOR CLOSURE

5 ITERATION PARAMETERS

8365 ELEMENTS IN X ARRAY ARE USED BY SIP

28482 ELEMENTS OF X ARRAY USED OUT OF 100000

BOUNDARY ARRAY $=$

-1 FOR LAYER 1

BOUNDARY ARRAY FOR LAYER 2 WILL BE READ ON UNIT 1 USING FORMAT: (20I3)

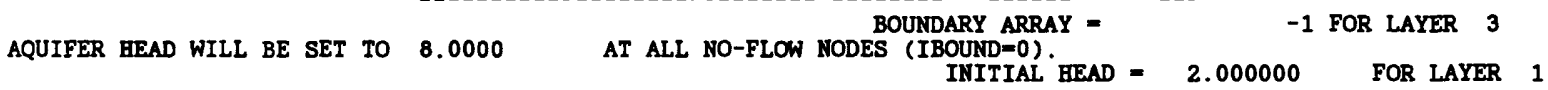

INITIAL HEAD FOR LAYER 2 WILL BE READ ON UNIT 1 USING FORMAT: $(10 F 7.0,1,10 F 7.0)$

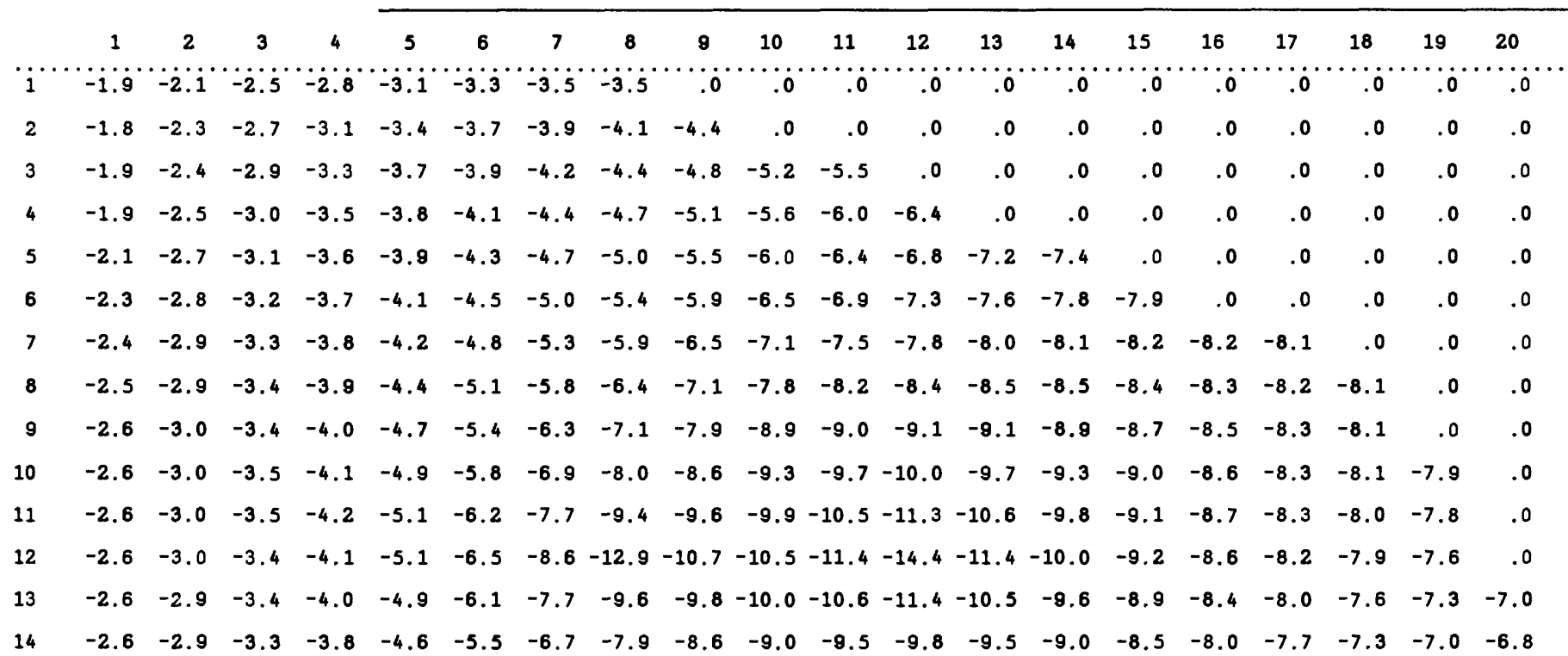




\begin{tabular}{|c|c|c|c|c|c|c|c|c|c|c|c|c|c|c|c|c|c|c|c|c|}
\hline 15 & -2.6 & -2.9 & -3.3 & -3.7 & -4.2 & -5.0 & -5.9 & -7.0 & -7.6 & -8.0 & -8.4 & -8.6 & -8.5 & -8.2 & -7.9 & -7.6 & -7.2 & -7.0 & -6.7 & -6.5 \\
\hline 16 & -2.6 & -2.9 & -3.2 & -3.5 & -4.0 & -4.5 & -5.4 & -6.9 & -6.8 & -7.0 & -7.3 & -7.5 & -7.5 & -7.4 & -7.2 & -7.0 & -6.8 & -6.6 & -6.3 & -6.2 \\
\hline 17 & 2.6 & -2.9 & -3.2 & -3.4 & -3.7 & -4.1 & -4.6 & -5.3 & -5.6 & -5.9 & -6.2 & -6.4 & -6.5 & -6.6 & -6.6 & -6.5 & -6.4 & -6.1 & -5.9 & -5.8 \\
\hline 18 & -2.7 & -2.9 & -3.1 & -3.3 & -3.5 & -3.8 & -4.1 & -4.4 & -4.7 & -4.9 & -5.2 & -5.5 & -5.7 & -5.8 & -6.0 & -6.0 & -6.0 & -5.7 & -5.5 & -5.4 \\
\hline 18 & -2.8 & -2.9 & -3.1 & -3.3 & -3.4 & -3.6 & -3.7 & -3.9 & -4.0 & -4.3 & -4.5 & -4.8 & -5.0 & -5.2 & -5.4 & -5.7 & -6.0 & -5.6 & -5.3 & -5.2 \\
\hline 0 & -2.8 & -2.9 & -3.0 & -3.2 & -3.3 & -3.4 & -3.5 & -3.6 & -3.7 & -3.8 & -4.0 & -4.2 & -4.5 & -4.7 & -5.0 & -5.5 & -6.5 & -5.5 & -5.1 & -5.0 \\
\hline 21 & -2.8 & -2.8 & -3.0 & -3.1 & -3.2 & -3.3 & -3.4 & -3.4 & -3.5 & -3.5 & -3.6 & -3.8 & -4.0 & -4.3 & -4.6 & -4.9 & -5.2 & -5.0 & -4.8 & -4.7 \\
\hline 22 & -2.8 & -2.9 & -3.0 & -3.1 & -3.1 & -3.2 & -3.3 & -3.3 & -3.4 & -3.4 & -3.5 & -3.6 & -3.7 & -3.9 & -4.1 & -4.3 & -4.5 & -4.5 & -4.4 & -4.4 \\
\hline 23 & -2.8 & -2.8 & -2.9 & -3.0 & -3.1 & -3.1 & -3.2 & -3.2 & -3.3 & -3.3 & -3.3 & -3.4 & -3.6 & -3.7 & -3.8 & -3.9 & -4.0 & -4.1 & -4.1 & -4.1 \\
\hline 24 & -2.7 & -2.8 & -2.9 & -2.9 & -3.0 & -3.0 & -3.1 & -3.1 & -3.2 & -3.2 & -3.3 & -3.4 & -3.5 & -3.6 & -3.6 & -3.7 & -3.7 & -3.8 & -3.8 & -3.8 \\
\hline 25 & -2.7 & -2.7 & -2.8 & -2.9 & -2.9 & -3.0 & -3.0 & -3.1 & -3.1 & -3.2 & -3.2 & -3.3 & -3.7 & -3.5 & -3.4 & -3.4 & -3.5 & -3.5 & -3.5 & -3.5 \\
\hline & -2.6 & -2.7 & -2.7 & -2.8 & -2.9 & -2.9 & -3.0 & -3.0 & -3.0 & -3.1 & -3.1 & -3.2 & -3.3 & -3.2 & -3.2 & -3.2 & -3.3 & -3 & -3.3 & -3.3 \\
\hline & -2. & -2 & -2.7 & -2.7 & -2.8 & -2.8 & -2.8 & -2 . & -3.0 & -3.0 & -3.0 & -3.1 & -3.1 & -3.1 & -3.1 & -3 & -3.1 & -3.1 & -3.1 & -3.1 \\
\hline 28 & -2.5 & -2.5 & -2.6 & -2.7 & -2.7 & -2.8 & -2.8 & -2. & -2.9 & -2.9 & -3.0 & -3.0 & -3.0 & -3.0 & -3 & & -3.0 & & & -3.0 \\
\hline 2 & -2.4 & -2.5 & -2.5 & -2.6 & -2.6 & -2.7 & -2.7 & -2.8 & -2.8 & -2.9 & -2.9 & -2.9 & -2.9 & -2.9 & -2.9 & -2.9 & -2.9 & -2.8 & -2.8 & -2.8 \\
\hline 30 & -2.3 & -2.4 & -2.4 & -2.5 & -2.6 & -2.6 & -2.7 & -2.7 & -2.8 & -2.8 & -2.8 & -2.8 & -2.8 & -2.8 & -2.8 & -2.8 & -2.8 & -2.8 & -2.8 & -2.7 \\
\hline 31 & -2.2 & -2.3 & -2.3 & -2.4 & -2.5 & -2.5 & -2.6 & -2.6 & -2.7 & -2.7 & -2.7 & -2.7 & -2.7 & -2.7 & -2.7 & -2.7 & -2.7 & -2.7 & -2.7 & -2.7 \\
\hline 32 & -2.0 & -2.1 & -2.2 & -2.3 & -2.4 & -2.5 & -2.5 & -2.6 & -2.6 & -2.6 & -2.7 & -2.7 & -2.7 & -2.7 & -2.7 & -2.7 & -2.6 & -2.6 & -2.6 & -2.6 \\
\hline 33 & -1.9 & -2.0 & -2.1 & -2.2 & -2.3 & -2.4 & -2.4 & -2.5 & -2.5 & -2.6 & -2.6 & -2.6 & -2.6 & -2.6 & & & -2.6 & -2.6 & -2.6 & -2.6 \\
\hline 34 & -1.8 & -1.8 & -1.9 & -2.0 & -2.1 & -2.2 & -2.3 & -2.4 & -2.5 & -2.5 & -2.5 & -2.6 & -2.6 & -2.6 & -2.6 & -2.6 & -2.6 & -2.5 & -2.5 & -2.5 \\
\hline
\end{tabular}

INITIAL HEAD $=4.000000 \quad$ POR LAYER 3

HEAD PRINT FORMAT IS FORMAT IUMBER 8 DRAWDOWN PRINT FORMAT IS FORMAT WUMBER 8

HEADS WILL BE SAVED ON UNIT 25 DRAWDOWNS WILL BE SAVED ON UNIT 25

OUTPUT CONTROL IS SPECIFIED EVERY TIME STEP

COLUMN TO RON ANISOTROPY $=1.000000$

DETR $=1000.000$

DELC $=1000.000$

TRANSMIS. ALONG ROWS $=100.0000$

FOR LAYER 1

VERT HYD COND /THICKANESS $=.1500000$ E-05 FOR LAYER 1 


\begin{tabular}{|c|c|c|c|c|c|c|c|c|c|c|c|c|c|c|c|c|c|c|c|c|}
\hline & 1 & 2 & 3 & 4 & 5 & 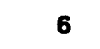 & 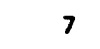 & 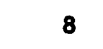 & . & 10 & 11 & 12 & 3 & 14 & 5 & 6 & 7 & 8 & 9 & 20 \\
\hline & 1 i. & 531. & 40. & 60. & 40. & 531. & 450. & 270 & 0. & 0. & 0. & 0. & & & & & & . & . & 0. \\
\hline 2 & 85. & 630. & 675. & 720 & 765. & 765. & 630. & 405. & 180. & 0. & 0. & 0. & 0. & 0. & 0 . & o. & 0. & . & 0. & o. \\
\hline 3 & 10. & 900 . & 0. & 40. & 0. & 00. & 50. & 810. & 585. & 360. & 180. & 0. & 0. & 0. & 0. & . & 0. & . & 0. & . \\
\hline 4 & 50. & 1440. & 1890. & 70. & 20. & 310. & 70. & 1170 & 630. & 450. & 360. & & 0. & 0. & 0. & 0. & 0. & 0. & 0. & 0. \\
\hline 5 & 50. & 30. & 0. & & & & & & 810. & 675. & 540. & & 5. & & 0. & 0. & 0. & 0. & 0. & 0 \\
\hline 6 & 40. & 3330 . & 20. & 20. & 0. & 70. & 90. & 40. & 1440. & 720. & 675. & 540. & & 15. & & 0. & 0. & 0. & 0. & 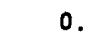 \\
\hline 7 & 70. & 60. & 3780 & 00. & & 880 . & 10. & 30. & 10. & 1170 & 810. & 720. & 630. & 540. & & 288. & & 0. & 0. & 0 \\
\hline 8 & & 20. & 70. & 00. & & 80. & & & & 30. & & & & & & & & & 0. & \\
\hline 8 & 00 & 40. & & & & & & & & & & & 5. & & & & & & 0. & \\
\hline 10 & & 3780. & 3150. & 2520 & & 340. & 50. & 160. & 1980 & 1620 & 1350. & & 900. & 765. & & 630. & 495. & 315. & & 0 \\
\hline & & & 10. & & & & & 10. & 20. & 30. & & & & & & & & & & \\
\hline 12 & & & 00 & & & & & 40. & 50. & 70. & & & & & & & & & & 0 \\
\hline & 4500 & 3870 . & 3150. & 50. & 00. & & & 1260 & 1080 & 900. & 720. & 675. & 675. & 630. & 585. & 540. & & & 15. & \\
\hline & & & 3690 & & & & & & 810 & 720. & 630 & & & 540. & & & & & & \\
\hline & & & 4050 & 3330 & & 90. & & 990. & 810. & 630. & 495. & & & & & & 342. & & & \\
\hline & 50. & 80. & 4500. & & & & & 990. & 720 & 495. & 405. & & & & & & & & & \\
\hline & & & 4680 & & & & & & 630 & 468. & & & & & & & & & & \\
\hline & & & 4680 & 4590 & & & & & 810. & 540. & 360. & & & & & & & & & \\
\hline & & & 4320 & 4590 & & 70. & & 1890 & 990. & 630. & 450. & 315. & 31 & 315. & & o. & 360. & & & 50 \\
\hline & & & & & & & & & & 900 & 540. & 36 & & & & & & & & \\
\hline & & & 3780 & 3960. & & & & & & & 720 & 54 & & & & & & & & \\
\hline & 30. & 3420 . & 3510. & 3600 & 3780 & 3870 & 70. & 80. & 3600 & 50. & 1260 & 720. & & & & & o. & & 56. & 38 \\
\hline & & & 3330 . & & & & & & 3690 & & 180 & & & & & & & & & \\
\hline & & & 3150. & 3240 & 330. & 20. & & & 3690 & 3690. & 970. & 300. & & 720. & 675. & 20. & 765. & 792. & 10. & 65 \\
\hline & & & & & & & & & & & 360 & . & & & & & & & & 65 \\
\hline & & & & & & & & & 330. & & 30 & & & & & & & & & \\
\hline & & & & & & & & & & & & & & & & & & & & \\
\hline & ת? & & 1800 & & 250 & & & & 2880 & 3060 & 3240 & 330 & 324 & 970. & 100. & & & & 1. & \\
\hline & & & & & & & & & & & & & & & & & & & & (1) \\
\hline & & & & & & & & & & & & & & & & & & & & \\
\hline & & & 900 & & & & & & & & & & & & & & & & & \\
\hline & & & 72 & & 900. & & & & 320. & 1800. & 2070 & 2250 & 2520 & 100. & 2790 & 2790 & 2250 & 1800. & 1440. & 990 \\
\hline & & & & & & & & & & & & & & & & & & & & \\
\hline & & 780 & 8 & . & & & & & & & & & & & & & & & & \\
\hline
\end{tabular}


VERT GYD COND /THICKNESS - .1500000E-05 FOR LAYER 2 TRANSMIS. ALONG ROWS $=100.0000 \quad$ FOR LAYER 3

SOLUTION BY THE STRONGLY IMPLICIT PROCEDURE

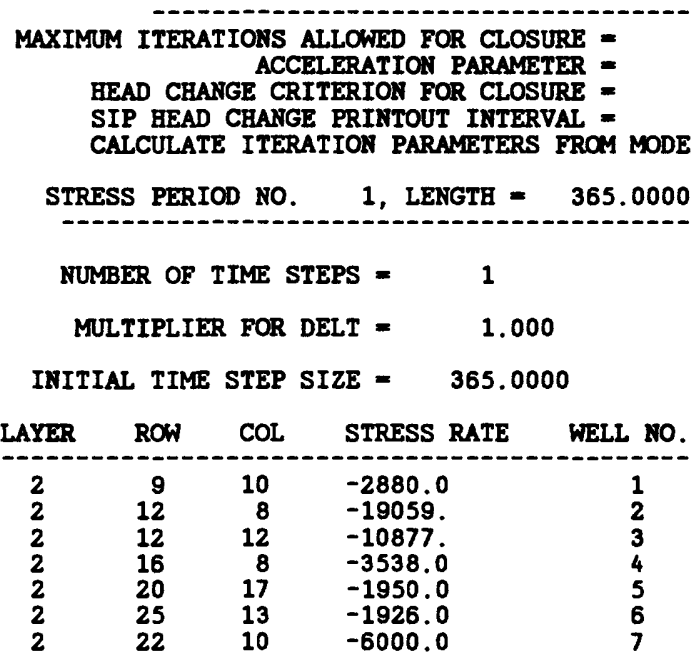

60 HEAD-DEPENDENT BOUNDARY NODES

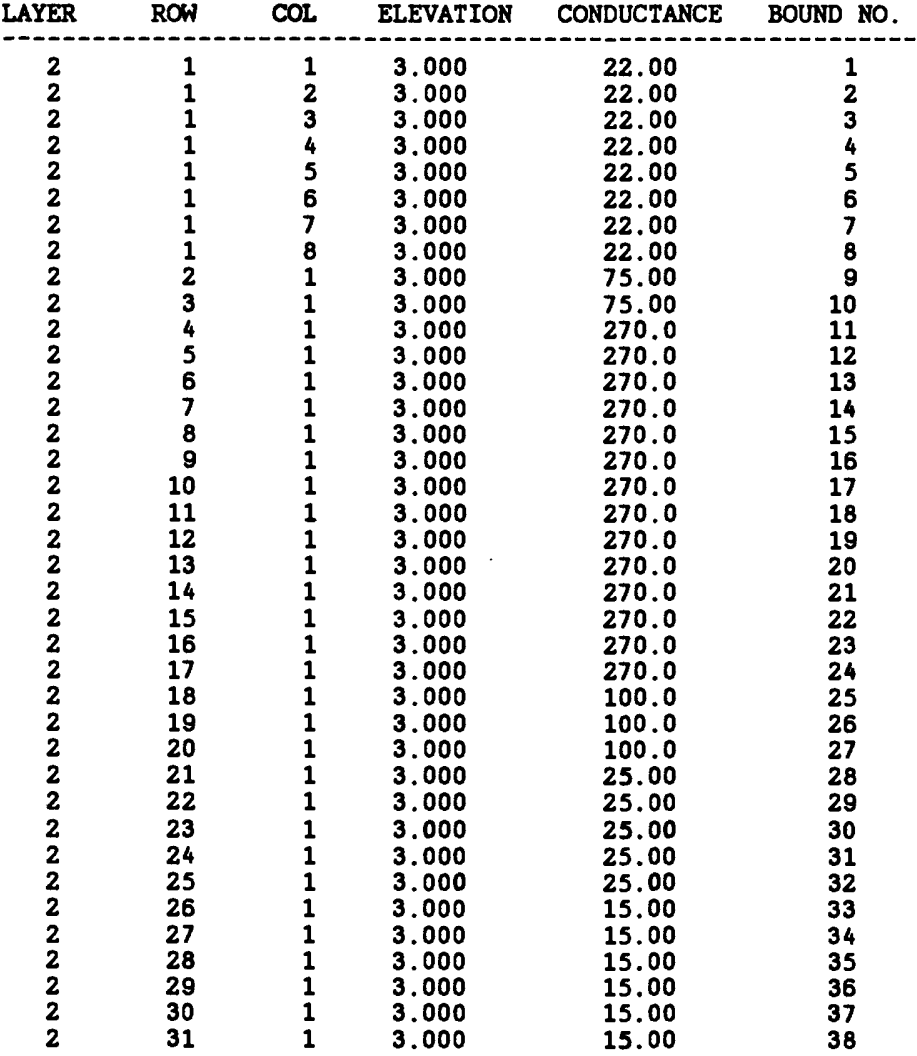




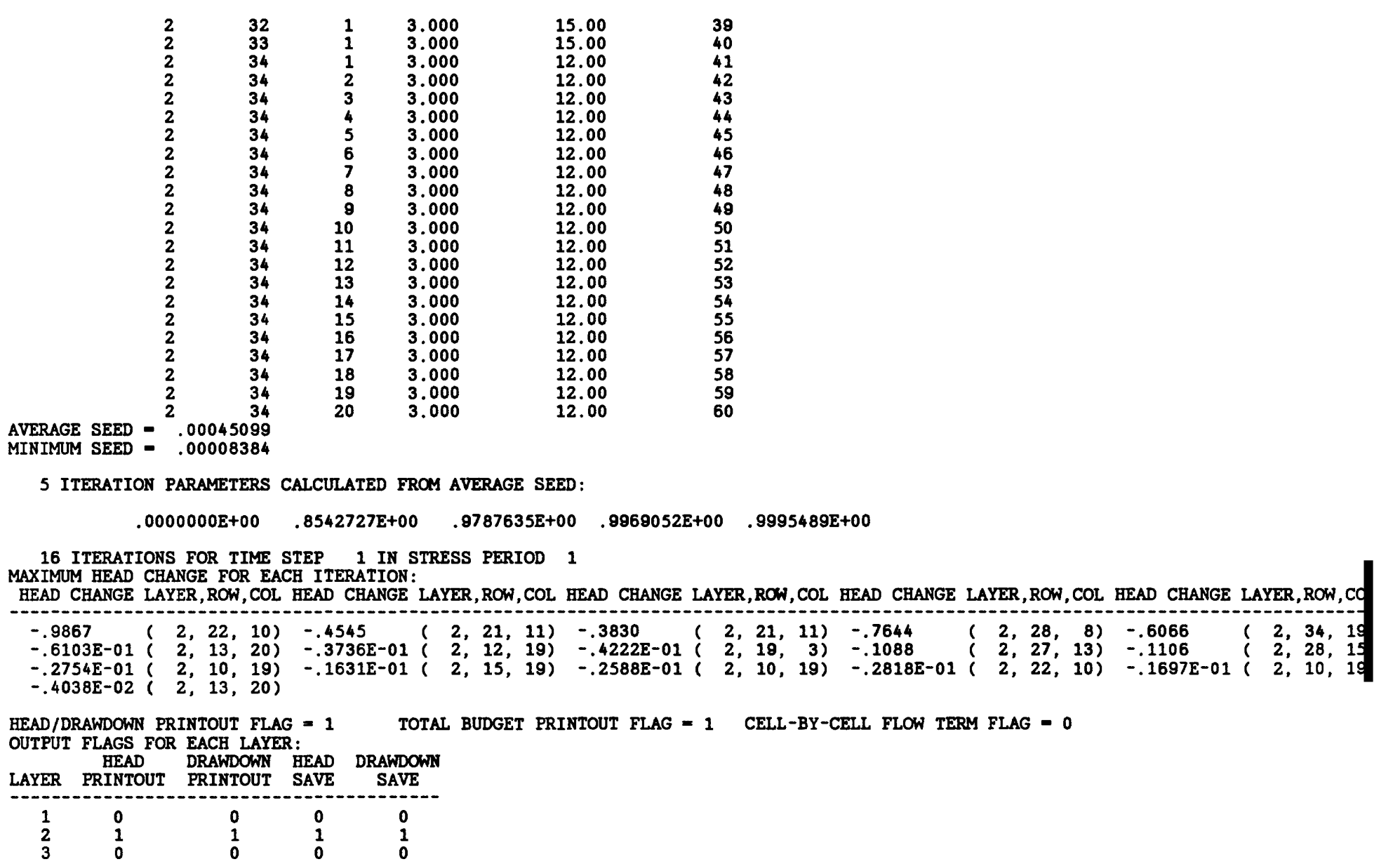




\begin{tabular}{|c|c|c|c|c|c|c|c|c|c|c|c|c|c|c|c|c|c|c|c|c|}
\hline & 1 & 2 & 3 & 4 & 5 & 6 & 7 & 8 & 9 & 10 & 11 & 12 & 13 & 14 & 15 & 16 & 17 & 18 & 19 & 20 \\
\hline$\ddot{1}$ & $\ddot{-2} \ddot{i}$ & $-2 . \dot{5}$ & -2.8 & -3.2 & -3.5 & -3.7 & $\ddot{-3} \dot{\theta}$ & $-3 . \dot{9}$ & $\ddot{8} \dot{0}$ & $\ddot{8} .0$ & $\ddot{8} \ddot{0}$ & $\ddot{8} .0$ & $\ddot{8} .0$ & $\ddot{8} .0$ & $\ddot{8} .0$ & $\ddot{8.0}$ & $\ddot{8} .0$ & $\ddot{8.0}$ & $\ddot{8} \ddot{0}$ & $\ddot{8} . \dot{0}$ \\
\hline 2 & -2.1 & -2.6 & -3.1 & -3.5 & -3.8 & -4.1 & -4.3 & -4.5 & -4.8 & 8.0 & 8.0 & 8.0 & 8.0 & 8.0 & 8.0 & 8.0 & 8.0 & 8.0 & 8.0 & 8.0 \\
\hline 3 & -2.2 & -2.8 & -3.3 & -3.7 & -4.1 & -4.4 & -4.6 & -4.8 & -5.3 & -5.7 & -6.0 & 8.0 & 8.0 & 8.0 & 8.0 & 8.0 & 8.0 & 8.0 & 8.0 & 8.0 \\
\hline 4 & -2.2 & -2.9 & -3.5 & -3.8 & -4.3 & -4.6 & -4.9 & -5.2 & -5.6 & -6.0 & -6.5 & -6.8 & 8.0 & 8.0 & 8.0 & 8.0 & 8.0 & 8.0 & 8.0 & 8.0 \\
\hline 5 & -2.5 & -3.1 & -3.6 & -4.0 & -4.4 & -4.8 & -5.1 & -5.5 & -6.0 & -6.5 & -6.9 & -7.4 & -7.8 & -8.0 & 8.0 & 8.0 & 8.0 & 8.0 & 8.0 & 8.0 \\
\hline 6 & -2.7 & -3.2 & -3.7 & -4.1 & -4.6 & -5.0 & -5.5 & -5.9 & -6.4 & -7.0 & -7.5 & -7.8 & -8.1 & -8.3 & -8.5 & 8.0 & 8.0 & 8.0 & 8.0 & 8.0 \\
\hline 7 & -2.8 & -3.3 & -3.8 & -4.2 & -4.7 & -5.3 & -5.8 & -6.4 & -7.0 & -7.6 & -8.1 & -8.54 & -8.6 & -8.7 & -8.7 & -8.7 & -8.7 & 8.0 & 8.0 & 8.0 \\
\hline 8 & -3.0 & -3.4 & -3.8 & -4.4 & -5.0 & -5.6 & -6.3 & -7.0 & -7.7 & -8.4 & -8.8 & -9.0 & -9.1 & -9.1 & -9.0 & -8.9 & -8.8 & -8.6 & 8.0 & 8.0 \\
\hline 9 & -3.0 & -3.4 & -3.9 & -4.5 & -5.2 & -6.0 & -6.8 & -7.7 & -8.5 & -9.5 & -9.6 & -9.7 & -9.7 & -9.5 & -9.3 & -9.1 & -8.9 & -8.7 & 8.0 & 8.0 \\
\hline 10 & -3.1 & -3.5 & -4.0 & -4.7 & -5.5 & -6.4 & -7.5 & -8.6 & -9.3 & -9.9 & -10.3 & -10.6 & -10.4 & -10.0 & -9.6 & -9.3 & -9.0 & -8.7 & -8.5 & 8.0 \\
\hline 11 & -3.1 & -3.5 & -4.1 & -4.8 & -5.7 & -6.9 & -8.4 & -10.1 & -10.3 & -10.6 & -11.2 & -11.9 & -11.2 & -10.4 & -9.8 & -9.3 & -9.0 & -8.7 & -8.5 & 8.0 \\
\hline 12 & -3.2 & -3.6 & -4.1 & -4.8 & -5.8 & -7.2 & -9.4 & -13.6 & -11.4 & -11.2 & -12.1 & -15.1 & -12.1 & -10.7 & -9.9 & -9.3 & -8.9 & -8.6 & -8.3 & 8.0 \\
\hline 13 & -3.2 & -3.6 & -4.1 & -4.8 & -5.6 & -6.9 & -8.5 & -10.4 & -10.6 & -10.8 & -11.4 & -12.2 & -11.3 & -10.4 & -9.7 & -9.1 & -8.7 & -8.4 & -8.1 & -7.8 \\
\hline 14 & -3.3 & -3.7 & -4.1 & -4.7 & -5.4 & -6.4 & -7.5 & -8.8 & -9.4 & -9.9 & -10.3 & -10.6 & -10.3 & -9.8 & -9.3 & -8.8 & -8.4 & -8.1 & -7.8 & -7.6 \\
\hline 15 & -3.4 & -3.7 & -4.1 & -4.6 & -5.2 & -6.0 & -6.9 & -8.0 & -8.5 & -9.0 & -9.3 & -9.5 & -9.4 & -9.1 & -8.8 & -8.4 & -8.1 & -7.8 & -7.6 & -7.4 \\
\hline 16 & -3.5 & -3.8 & -4.2 & -4.5 & -5.0 & -5.6 & -6.5 & -8.0 & -7.9 & -8.1 & -8.3 & -8.5 & -8.5 & -8.4 & -8.2 & -7.9 & -7.7 & -7.5 & -7.2 & -7.1 \\
\hline 17 & -3.6 & -3.9 & -4.2 & -4.5 & -4.8 & -5.3 & -5.8 & -6.5 & -6.9 & -7.2 & -7.4 & -7.6 & -7.7 & -7.7 & -7.7 & -7.6 & -7.4 & -7.1 & -6.9 & -6.8 \\
\hline 18 & -3.7 & -4.0 & -4.2 & -4.5 & -4.6 & -5.1 & -5.4 & -5.8 & -6.1 & -6.4 & -6.7 & -6.9 & -7.0 & -7.1 & -7.2 & -7.2 & -7.1 & -6.9 & -6.6 & -6.5 \\
\hline 19 & -3.9 & -4.1 & -4.3 & -4.5 & -4.7 & -4.9 & -5.2 & -5.4 & -5.7 & -6.0 & -6.2 & -6.4 & -6.5 & -6.6 & -6.7 & -7.0 & -7.2 & -6.8 & -6.5 & -6.4 \\
\hline 20 & -3.9 & -4.1 & -4.3 & -4.5 & -4.7 & -4.9 & -5.1 & -5.3 & -5.5 & -5.8 & -5.9 & -6.0 & -6.1 & -6.3 & -6.4 & -6.9 & -7.8 & -6.8 & -6.4 & -6.2 \\
\hline 21 & -4.1 & -4.2 & -4.3 & -4.5 & -4.7 & -4.9 & -5.0 & -5.3 & -5.5 & -5.9 & -5.8 & -5.9 & -5.9 & -6.1 & -6.3 & -6.5 & -6.3 & -6.1 & -6.1 & -6.0 \\
\hline 22 & -4.1 & -4.2 & -4.3 & -4.5 & -4.6 & -4.8 & -5.0 & -5.2 & -5.6 & -6.4 & -5.9 & -5.7 & -5.6 & -5.6 & -5.7 & -5.8 & -5.9 & -5.8 & -5.8 & -5.7 \\
\hline 23 & -4.1 & -4.2 & -4.3 & -4.5 & -4.6 & -4.8 & -4.9 & -5.1 & -5.3 & -5.6 & -5.5 & -5.5 & -5.4 & -5.4 & -5.4 & -5.5 & -5.5 & -5.5 & -5.5 & -5.4 \\
\hline 24 & -4.1 & -4.2 & -4.3 & -4.4 & -4.6 & -4.7 & -4.8 & -5.0 & -5.1 & -5.2 & -5.2 & -5.3 & -5.3 & -5.3 & -5.2 & -5.2 & -5.2 & -5.2 & -5.2 & -5.2 \\
\hline 25 & -4.1 & -4.2 & -4.3 & -4.4 & -4.5 & -4.6 & -4.7 & -4.9 & -5.0 & -5.0 & -5.1 & -5.1 & -5.4 & -5.1 & -5.0 & -5.0 & -4.9 & -4.9 & -4.9 & -4.9 \\
\hline 27 & -4.0 & -4.1 & -4.2 & -4.2 & -4.3 & -4.4 & -4.5 & -4.6 & -4.7 & -4.7 & -4.7 & -4.8 & -4.8 & -4.7 & -4.6 & -4.6 & -4.6 & -4.6 & -4.6 & -4.6 \\
\hline 28 & -3.9 & -4.0 & -4.1 & -4.2 & -4.3 & -4.3 & -4.4 & -4.5 & -4.5 & -4.6 & -4.6 & -4.6 & -4.6 & -4.6 & -4.5 & -4.5 & -4.4 & -4.4 & -4.4 & -4.4 \\
\hline 29 & -3.8 & -3.9 & -4.0 & -4.1 & -4.2 & -4.2 & -4.3 & -4.4 & -4.4 & -4.5 & -4.5 & -4.5 & -4.5 & -4.4 & -4.4 & -4.4 & -4.3 & -4.3 & -4.3 & -4.3 \\
\hline 30 & -3.7 & -3.8 & -3.9 & -4.0 & -4.1 & -4.1 & -4.2 & -4.3 & -4.3 & -4.4 & -4.4 & -4.4 & -4.4 & -4.3 & -4.3 & -4.3 & -4.2 & -4.2 & -4.2 & -4.2 \\
\hline 31 & -3.5 & -3.6 & -3.7 & -3.9 & -3.9 & -4.0 & -4.1 & -4.2 & -4.2 & -4.3 & -4.3 & -4.3 & -4.3 & -4.3 & -4.2 & -4.2 & -4.2 & -4.1 & -4.1 & -4.1 \\
\hline 32 & -3.3 & -3.5 & -3.6 & -3.7 & -3.8 & -3.9 & -4.0 & -4.1 & -4.1 & -4.2 & -4.2 & -4.2 & -4.2 & -4.2 & -4.2 & -4.1 & -4.1 & -4.1 & & \\
\hline 33 & -3.2 & -3.3 & -3.4 & -3.6 & -3.7 & -3.8 & -3.9 & -4.0 & -4.0 & -4.1 & -4.1 & -4.1 & -4.1 & -4.1 & -4.1 & -4.1 & -4.0 & -4.0 & -4.0 & -4.0 \\
\hline 34 & -3.0 & -3.1 & -3.2 & -3.4 & -3.5 & -3.6 & -3.7 & -3.8 & -3.9 & -4.0 & -4.0 & -4.0 & -4.1 & -4.1 & -4.0 & -4.0 & -4.0 & -4.0 & -3 & -3.9 \\
\hline
\end{tabular}

BEAD WILL BE SAVED ON UNIT 25 AT END OF TIME STEP 1 , STRESS PERIOD 1 


\begin{tabular}{|c|c|c|c|c|c|c|c|c|c|c|c|c|c|c|c|c|c|c|c|c|}
\hline & 1 & 2 & 3 & 4 & 5 & 6 & 7 & 8 & 9 & 10 & 11 & 12 & 13 & 14 & 15 & 16 & 17 & 18 & 19 & 20 \\
\hline 1 & 3 & 3 & $\ddot{4}^{\circ}$ & .4 & .4 & .4 & .4 & .4 & 8.0 & 8.0 & 8.0 & 8.0 & 8.0 & 8.0 & 8.0 & 8.0 & 8.0 & 8.0 & 8.0 & 8.0 \\
\hline 2 & .3 & .4 & .4 & .4 & .4 & .4 & .4 & .4 & .4 & 8.0 & 8.0 & 8.0 & 8.0 & 8.0 & 6.0 & 8.0 & 8.0 & 8.0 & 8.0 & 8.0 \\
\hline 3 & .3 & .4 & .4 & .4 & .4 & .4 & .4 & .5 & .5 & .5 & .5 & 8.0 & 8.0 & 8.0 & 8.0 & 8.0 & 8.0 & 6.0 & 8.0 & 8.0 \\
\hline 4 & .3 & .4 & .4 & .4 & .4 & .4 & .5 & .5 & .5 & .5 & .5 & .5 & 8.0 & 8.0 & 8.0 & 8.0 & 8.0 & 8.0 & 8.0 & 8.0 \\
\hline 5 & .4 & .4 & .4 & .4 & .5 & .5 & .5 & .5 & .5 & .5 & .5 & .5 & .5 & .5 & 8.0 & 8.0 & 8.0 & 8.0 & 8.0 & 8.0 \\
\hline 6 & .4 & .4 & .4 & .5 & .5 & .5 & .5 & .5 & .5 & .5 & .5 & .5 & .5 & .5 & .6 & 8.0 & 8.0 & 8.0 & 8.0 & 8.0 \\
\hline 7 & .4 & .4 & .5 & .5 & .5 & .5 & .5 & .5 & .5 & .5 & .6 & .6 & .6 & .6 & .6 & .6 & .6 & 8.0 & 8.0 & 8.0 \\
\hline 8 & .4 & .5 & .5 & .5 & .5 & .5 & .5 & .6 & .6 & .6 & .6 & .6 & .6 & .6 & .6 & .6 & .6 & .6 & 8.0 & 8.0 \\
\hline 9 & .5 & .5 & .5 & .5 & .5 & .6 & .6 & .6 & .6 & .6 & .6 & .6 & .6 & .6 & .6 & .6 & .6 & .6 & 8.0 & 8.0 \\
\hline 10 & .5 & .5 & .5 & .6 & .6 & .6 & .6 & .6 & .6 & .6 & .6 & .6 & .6 & .6 & .6 & .6 & .6 & .6 & .6 & 8.0 \\
\hline 11 & .5 & .6 & .6 & .6 & .6 & .6 & .7 & .7 & .7 & .7 & .7 & .7 & .7 & .7 & .7 & .7 & .7 & .7 & .7 & 8.0 \\
\hline 12 & .6 & .6 & .7 & .7 & .7 & .7 & .7 & .7 & .7 & .7 & .7 & .7 & .7 & .7 & .7 & .7 & .7 & .7 & .7 & 8.0 \\
\hline 13 & .7 & .7 & .7 & .7 & .8 & .8 & .8 & .8 & .8 & .8 & .8 & .8 & .8 & .7 & .7 & .7 & .7 & .7 & .7 & .7 \\
\hline 14 & .7 & .8 & .8 & .8 & .9 & .9 & .9 & .9 & .9 & .9 & .8 & .8 & .8 & .8 & .8 & .8 & .8 & .8 & .8 & .8 \\
\hline 15 & .8 & .8 & .9 & 1.0 & 1.0 & 1.0 & 1.0 & 1.0 & .9 & .9 & .9 & .9 & .9 & .9 & .9 & .8 & .8 & .8 & .8 & .8 \\
\hline 16 & .9 & .9 & .9 & 1.0 & 1.0 & 1.1 & 1.1 & 1.1 & 1.1 & 1.1 & 1.1 & 1.1 & 1.0 & 1.0 & 1.0 & .9 & .9 & .9 & .9 & .9 \\
\hline 17 & .9 & 1.0 & 1.0 & 1.1 & 1.1 & 1.2 & 1.2 & 1.2 & 1.3 & 1.3 & 1.3 & 1.2 & 1.2 & 1.1 & 1.1 & 1.0 & 1.0 & 1.0 & 1.0 & 1.0 \\
\hline 18 & 1.0 & 1.1 & 1.1 & 1.2 & 1.2 & 1.3 & 1.3 & 1.4 & 1.5 & 1.5 & 1.5 & 1.4 & 1.3 & 1.3 & 1.2 & 1.1 & 1.1 & 1.1 & 1.1 & 1.1 \\
\hline 19 & 1.1 & 1.1 & 1.2 & 1.2 & 1.3 & 1.4 & 1.5 & 1.5 & 1.7 & 1.7 & 1.7 & 1.6 & 1.5 & 1.4 & 1.3 & 1.3 & 1.2 & 1.2 & 1.2 & 1.2 \\
\hline 20 & 1.2 & 1.2 & 1.2 & 1.3 & 1.4 & 1.5 & 1.6 & 1.7 & 1.9 & 2.0 & 2.0 & 1.8 & 1.7 & 1.5 & 1.4 & 1.4 & 1.3 & 1.3 & 1.3 & 1.3 \\
\hline 21 & 1.2 & 1.3 & 1.3 & 1.4 & 1.4 & 1.5 & 1.7 & 1.8 & 2.1 & 2.4 & 2.2 & 2.0 & 1.8 & 1.6 & 1.5 & 1.4 & 1.4 & 1.3 & 1.3 & 1.3 \\
\hline 22 & 1.3 & 1.3 & 1.4 & 1.4 & 1.5 & 1.6 & 1.7 & 1.9 & 2.2 & 3.0 & 2.4 & 2.1 & 1.9 & 1.7 & 1.6 & 1.5 & 1.4 & 1.4 & 1.3 & 1.3 \\
\hline 23 & 1.3 & 1.4 & 1.4 & 1.5 & 1.5 & 1.6 & 1.7 & 1.9 & 2.1 & 2.3 & 2.2 & 2.0 & 1.9 & 1.7 & 1.6 & 1.5 & 1.4 & 1.4 & 1.4 & 1.4 \\
\hline 24 & 1.4 & 1.4 & 1.4 & 1.5 & 1.6 & 1.6 & 1.7 & 1.8 & 1.9 & 2.0 & 2.0 & 1.9 & 1.8 & 1.7 & 1.6 & 1.5 & 1.5 & 1.4 & 1.4 & 1.4 \\
\hline 25 & 1.4 & 1.4 & 1.5 & 1.5 & 1.6 & 1.6 & 1.7 & 1.8 & 1.8 & 1.9 & 1.9 & 1.8 & 1.7 & 1.7 & 1.6 & 1.5 & 1.5 & 1.4 & 1.4 & 1.4 \\
\hline 26 & 1.4 & 1.4 & 1.5 & 1.5 & 1.6 & 1.6 & 1.7 & 1.7 & 1.8 & 1.8 & 1.8 & 1.7 & 1.7 & 1.6 & 1.6 & 1.5 & 1.5 & 1.4 & 1.4 & 1.4 \\
\hline 27 & 1.4 & 1.4 & 1.5 & 1.5 & 1.5 & 1.6 & 1.6 & 1.7 & 1.7 & 1.7 & 1.7 & 1.7 & 1.7 & 1.6 & 1.6 & 1.5 & 1.5 & 1.5 & 1.4 & 1.4 \\
\hline 28 & 1.4 & 1.4 & 1.5 & 1.5 & 1.5 & 1.6 & 1.6 & 1.6 & 1.6 & 1.7 & 1.7 & 1.6 & 1.6 & 1.6 & 1.6 & 1.5 & 1.5 & 1.5 & 1.5 & 1.4 \\
\hline 29 & 1.4 & 1.4 & 1.5 & 1.5 & 1.5 & 1.5 & 1.6 & 1.6 & 1.6 & 1.6 & 1.6 & 1.6 & 1.6 & 1.6 & 1.5 & 1.5 & 1.5 & 1.5 & 1.5 & 1.4 \\
\hline 30 & 1.4 & 1.4 & 1.4 & 1.5 & 1.5 & 1.5 & 1.5 & 1.6 & 1.6 & 1.6 & 1.6 & 1.6 & 1.6 & 1.5 & 1.5 & 1.5 & 1.5 & 1.5 & 1.4 & 1.4 \\
\hline 31 & 1.4 & 1.4 & 1.4 & 1.4 & 1.5 & 1.5 & 1.5 & 1.5 & 1.5 & 1.5 & 1.5 & 1.5 & 1.5 & 1.5 & 1.5 & 1.5 & 1.5 & 1.5 & 1.4 & 1.4 \\
\hline 32 & 1.3 & 1.3 & 1.4 & 1.4 & 1.4 & 1.5 & 1.5 & 1.5 & 1.5 & 1.5 & 1.5 & 1.5 & 1.5 & 1.5 & 1.5 & 1.5 & 1.5 & 1.4 & 1.4 & 1.4 \\
\hline 33 & 1.3 & 1.3 & 1.3 & 1.4 & 1.4 & 1.4 & 1.5 & 1.5 & 1.5 & 1.5 & 1.5 & 1.5 & 1.5 & 1.5 & 1.5 & 1.5 & 1.4 & 1.4 & 1.4 & 1.4 \\
\hline 34 & 1.3 & 1.3 & 1.3 & 1.3 & 1.4 & 1.4 & 1.4 & 1.4 & 1.5 & 1.5 & 1.5 & 1.5 & 1.5 & 1.5 & 1.5 & 1.4 & 1.4 & 1.4 & 1.4 & 1.4 \\
\hline
\end{tabular}

DRAWDOWN WILL BE SAVED ON UNIT 25 AT END OF TIME STEP 1 , STRESS PERIOD 1 
VOLUMETRIC BUDGET FOR ENTIRE MODEL AT END OF TIME STEP 1 IN STRESS PERIOD 1

CUMULATIVE VOLUMES

$L * 3$

RATES FOR THIS TIME STE

IN:

STORAGE $=$
CONSTANT HEAD $=$
WELLS $=$
TOTAL IN =
OUT:

STORAGE =

.00000

$\begin{array}{ll}\text { WELLS }= & .00000 \\ \text { COTH } & .16874 \mathrm{E}+08\end{array}$

HEAD DEP BOUNDS $=\quad .00000$

TOTAL OUT $=\quad .16874 \mathrm{E}+08$

PERCENT DISCREPANCY =

-10928 .
IN :

STORAGE $=\quad .00000$

HEAD $=16106$.

HEAD DEP BOUNDS $=\quad 300000$

TOTAL IN $=\quad 46200$.

OUT:

STORAGE $=\quad 00000$

CONSTANT HEAD $=\quad .00000$

BEAD WELLS =

TOTAL OUT $=\quad 46230$

PERCENT DISCREPANCY =

$\begin{array}{lccccc}\text { TIME SUMMARY AT END OF TIME STEP } & 1 & \text { IN STRESS PERIOD } & 1 & \\ & \text { SECONDS } & \text { MINUTES } & \text { HOURS } & \text { DAYS } & \text { YEARS } \\ \text { TIME STEP LENGTH } & -315360 E+08 & 525600 & 8760.00 & 365.000 & .999316 \\ \text { RESS PERIOD TIME } & .315360 E+08 & 525600 . & 8760.00 & 365.000 & .999316 \\ \text { SIMULATION TIME } & .315360 E+08 & 525600 . & 8760.00 & 365.000 & .999316\end{array}$

